\title{
Membrane distillation hybrids for water production and energy efficiency enhancement: A critical review
}

\author{
N. Ghaffour ${ }^{\mathrm{a}}$, S. Soukane ${ }^{\mathrm{b}}$, J.-G. Lee ${ }^{\mathrm{a}, \mathrm{c}}$, Y. Kim ${ }^{\mathrm{a}}$, A. Alpatova ${ }^{\mathrm{a}}$ \\ ${ }^{a}$ King Abdullah University of Science and Technology (KAUST), Water Desalination and Reuse Center \\ (WDRC), Division of Biological \& Environmental Science \& Engineering (BESE), 23955-6900 Thuwal 23955- \\ 6900, Saudi Arabia, Tel.+966-128082180,Email:noreddine.ghaffour@kaust.edu.sa \\ ${ }^{\mathrm{b}}$ National Institute of Marine Science and Coastal Management, Campus Universitaire de Dely Ibrahim, Bois \\ des Cars, BP 19, 16320, Algiers, Algeria \\ ${ }^{c}$ Korea Institute of Industrial Technology, 89, Yangdaegiro-gil, Ipjang-myeon, Seobuk-gu, Cheonan-si, \\ Chungcheongnam-do, Republic of Korea
}

\begin{abstract}
With an ever-increasing demand in energy, constrained by strict environmental regulations, process development faces stringent design requirements further limited by intrinsic properties of inherent materials. Process hybridization is now considered as an improvement path to several limitations. Complementarity between processes is the essence of the hybridization concept, with the ultimate goal to design more eco-friendly, energy efficient process combinations delivering higher throughputs and boosting the thermodynamic limits of the existing mature technologies. Market size of membrane-based separation processes, widely used in desalination, water treatment and purification, is forecasted to grow significantly in the next decades. While desalination market is mainly shared between thermal processes and reverse osmosis (RO), advanced water treatment and purification rely mostly on membrane technology. Among the large span of available techniques stands membrane distillation (MD), to which a tremendous research effort has been dedicated during the last two decades. Although praised for its numerous advantages, this thermally-driven separation process still cannot withstand large production rates while maintaining energy efficiency. Hybridization of MD with existing technologies and other emerging processes is therefore at the leading edge. This literature review presents the state-of-the-art MD hybrids with different separation processes including RO, pressure retarded osmosis, forward osmosis, mechanical vapor compression, electrocoagulation, electrodialysis, multi-stage flash, multi-effect distillation, crystallization and adsorption with a focus on water production and energy efficiency enhancement. Each of these processes has advantages at the cost of more or less severe drawbacks and its association to MD offers improvement opportunities. Each variant is thoroughly reviewed with major contributions and knowledge gaps highlighted. Perspectives and recommendations are
\end{abstract}


emphasized in each case. Latest developments in MD and its energy consumption and optimization are also reported.

Keywords: Latest MD developments; Hybrid systems; Energy consumption and optimization; Desalination and water treatment; Energy efficiency.

\section{Contents}

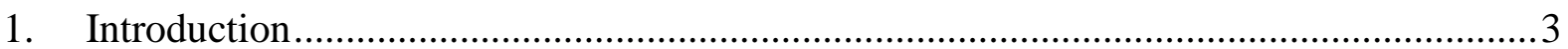

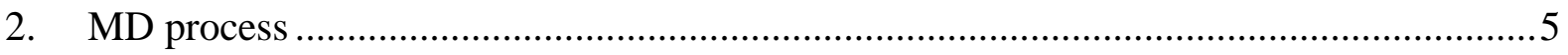

3. Hybridization of MD with conventional processes .................................................

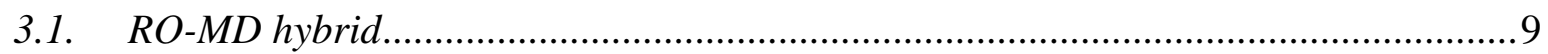



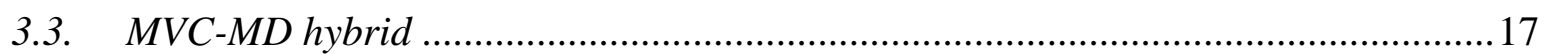

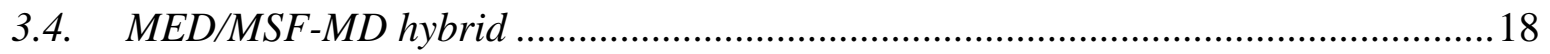

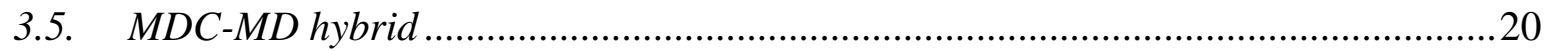

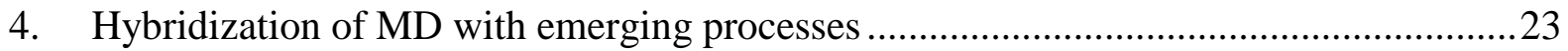

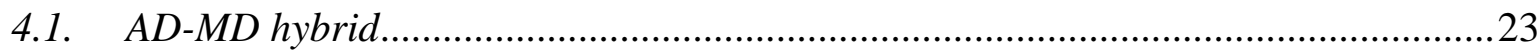

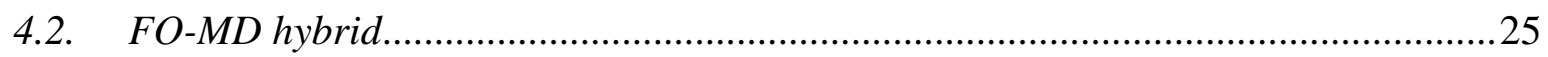

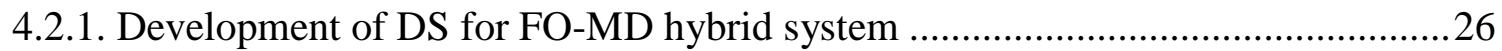

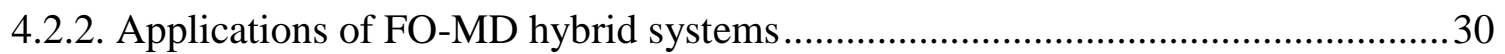

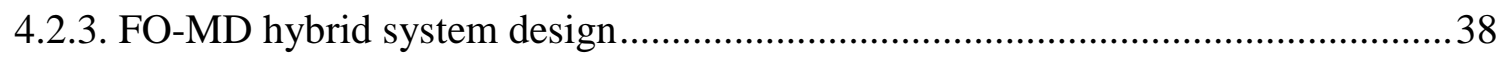

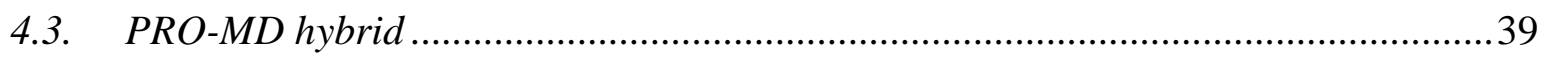

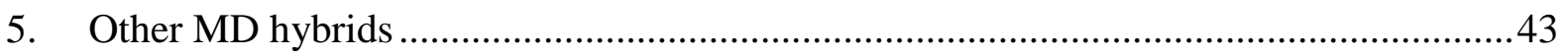

6. Hybridization current trends and perspectives.......................................................... 44

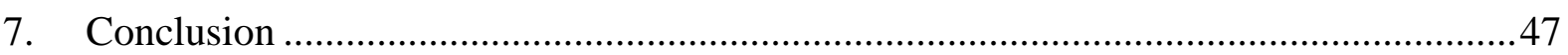

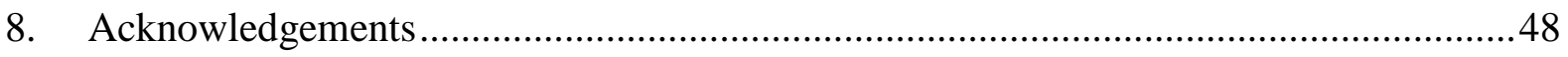

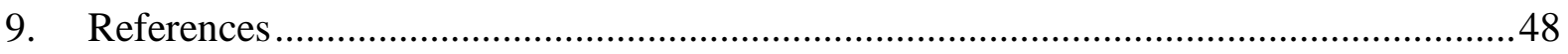




\section{INTRODUCTION}

Water is life! Yet more than 2 billion people do not have proper access to drinkable water [1]. The United Nations world water development report [2] gives in 2019, an annual average of 780,000 people killed from improper water and sanitation and an average of 55 million people affected by drought, causing more than US\$5 billion of economic damage. Water use experiences a $1 \%$ increase every year. The same rate has been observed since 1980 and is expected to last until 2050. Beyond human daily needs, water demand emanates from different sectors including energy production, agriculture and industry where it is used in various operations such as cooling and cleaning. However, water production and treatment comes at a cost and providing clean water to all populations remains a significant challenge. Many factors have to be taken into account such as energy availability, energy consumption, water recovery and environmental impact. A review by Plappally and Lienhard [3] gives energy consumption for different steps of water cycle including, production, treatment, supply, use and recycling. The authors report that established desalination processes, generally dominated by reverse osmosis (RO), except in Arabian Gulf where thermal-based multi-stage flash (MSF) and multieffect distillation (MED) prevail, remain an energy-consuming alternative for water treatment. Sparse values of energy consumption are reported in electrical equivalent per $\mathrm{m}^{3}$ of water, with most values falling between 2.5 and $7 \mathrm{kWh} / \mathrm{m}^{3}$. Regarding water treatment, membrane filtration is reported as the most energy intensive while digestion represents the highest energy consumption for wastewater treatment. Nevertheless, minimization of energy consumption is not the sole objective as water recovery also plays a critical role among many other factors related to environmental restrictions while full compliance to all constraints is often difficult in a single technology. Within this scope, focus is set on hybridization of membrane separation technologies particularly membrane distillation (MD) and unveil its potentialities for sustainable water desalination, treatment and reuse, whether by using its intrinsic ability of treating highly concentrated solutions or its affordability when low-grade waste heat is available.

Depending on the nature of the process, membrane separation may operate under different driving forces. A pressure difference is needed in microfiltration (MF), ultrafiltration (UF) and nanofiltration (NF), as well as in RO, while a chemical potential difference is needed in forward osmosis (FO) and pervaporation. Other processes such as electrodialysis (ED) and electroosmosis require an electric potential difference. Emerging techniques such as MD, although use a membrane, operate under temperature difference (vapor pressure difference). 
Each process has its advantages and drawbacks and sustaining the required driving force may face both physical and economical limitations. Hybridization is therefore considered if a single process does not produce the expected product quality or requires too much energy to withstand productivity and sustainability. The hybridization concept, often discussed for desalination to reach a more economical implementation [4-8] is now extensively considered for MD. MD has several attractive benefits, such as low operating temperatures as compared to the conventional distillation process, namely MSF and MED [8-10]. For instance, the feed solution does not require heat up to the boiling point and no vacuum is required in the feed tank. Due to relatively low operating temperatures, low grade waste heat and other alternative ecofriendly energy sources can be applied to heat up the MD feed. These include solar energy [11-18] and geothermal energy $[15,19]$. Moreover, MD can operate at atmospheric pressure unlike conventional pressure-driven membrane processes. In desalination by MD, the main system performance factors such as permeate flux and thermal efficiency are not very sensitive to feed water salinity. The rejection of salts is usually very high reaching almost $99.99 \%$ [20]. MD is also considered more cost effective since it uses inexpensive polymer and fitting materials which can also mitigate rust and corrosion issues often associated with costly stainless steel materials such as those used in high-pressure filtration [21, 22].

Since MD separation is based on chemical species volatility, the non-volatile feed constituents are systematically rejected. Therefore, another advantage of this process is its ability to carry out specific separation and desalination simultaneously. It has been proved to remove organic pollutants and salts from industrial or municipal wastewaters [23, 24], or radioactive metals from nuclear plant cooling water [25-27], or concentrating daily products (e.g., skim milk, juice) [28-30]. Weakly affected by feed water salinity, MD has been successfully tested through bench scale and pilot studies to treat brines from thermal-based desalination processes, mainly MSF and MED [31], as well as membrane-based processes, mainly RO [32, 33]. No severe fouling or scaling of the MD membranes was observed as these brines are carefully pretreated before the desalination process. Although, it has been shown that the MD process does not require extensive pretreatment even for the processing of hyper saline streams [34] or produced water [35, 36]. Nevertheless, long term operation testing is still needed to confirm these claims. Among all above-mentioned benefits, low sensitivity to feed salinity on system performance and moderate operating conditions such as low temperature and low pressure remain the most attractive MD characteristics. 
As any other process, MD has its drawbacks. Since it is a thermally-driven process, it remains an energy demanding technology $[37,38]$, although the process can be competitive at large scale using waste heat $[8,39-42]$. It presents several limitations, which are yet to be overcome, including relatively low permeate flux and water recovery ratio as compared to conventional membrane-based desalination such as RO. Other drawbacks of MD process are its high sensitivity to temperature polarization, high specific thermal energy consumption, proneness to membrane wetting, low separation of organic solvents with low surface tension, and significant heat loss by conduction. Moreover, trapped air within the membrane may affect mass transfer and reduce vapor flux across the membrane. Recent scale-up calculations show that, beyond a given number of stages, multi-stage configurations might exhibit an inversion phenomenon in water production [43].

Nevertheless, the variety of MD process configurations and its unique advantages [44-48] offer multiple options for integrating and hybridizing this process with other conventional and emerging separation processes to maximize water recovery and enhance energy and cost efficiency. Hybrid variants include but are not limited to reverse osmosis (RO-MD), forward osmosis (FO-MD), pressure-retarded osmosis (PRO-MD), crystallization (MDC), adsorption desalination (AD-MD), thermal processes (MSF/MED-MD), bioreactors (BR-MD), electrodialysis (ED-MD) and electrocoagulation (EC-MD). These systems will be thoroughly discussed throughout the current review with emphasis on advantages, limitations and future trends with a focus on water production and energy efficiency enhancement. To our knowledge, there is no reported critical review paper on MD hybrids.

\section{MD PROCESS}

MD is an emerging separation process that allows only water vapor to be transferred across a hydrophobic membrane [5, 8, 9, 20-22, 44, 49-55]. The process is driven by the difference of partial vapor pressure across the membrane, induced by the transmembrane temperature difference [9, 20, 49, 50, 56-61]. The vapor flux $J$ across the MD membrane is often expressed as:

$$
J=C_{m e m}\left(P_{f m}-P_{p m}\right)
$$

where $P_{f m}$ is the vapor pressure at the feed side of the membrane, $P_{p m}$ the vapor pressure at the permeate side of the membrane and $C_{m e m}$ the mass transfer coefficient.

Typically, mass transfer from feed to permeate is a function of the membrane structural properties such as mean pore size, porosity, thickness, and tortuosity, as well as operating 
conditions such as temperature and pressure at both sides of the membrane. Mass transfer is enhanced with larger mean pore size and porosity and a smaller thickness and tortuosity [50, 52, 62-66]. Theoretically, transport across the membrane is often considered as a mixed contribution of Knudsen and ordinary diffusion [20, 67-70].

MD membranes are predominantly cast of polymeric materials, which have low thermal conductivity and high hydrophobicity such as polytetrafluoroethylene (PTFE), polyvinylidene fluoride (PVDF), or polypropylene (PP). PTFE is the most commonly used polymer for its high thermal and chemical resistances. The membrane's thermal conductivity depend on the thermal conductivities of both polymer and air contained in the membrane's pores, thus function of membrane porosity. Common methods of membrane fabrication include lamination, phase inversion and electrospinning. Other type of membranes have been suggested such as composite polymeric membranes with thin active layer and thick support layer [71-75], or surface-coated and surface modified membranes [55, 76-83]. Due to its dual structure, a composite membrane is expected to increase the vapor flux due to lower mass transfer resistance [48]. Conduction heat losses are also reduced due to the presence of a thick support layer. Furthermore, the coated and surface-modified membranes can further reduce the mass transfer resistance and enhance membrane's hydrophobicity. As a matter of fact, a recent concept of omniphobic membrane has been introduced. The improved anti-fouling and antiwetting properties of this type of membranes allows to repel not only water, but also organic solvents which has a low surface tension such as cleaning agents, detergents, oils and chemicals [84-87].

The operating conditions such as inlet feed and permeate temperatures as well as inlet feed and permeate flow rates have significant effect on system performance including thermal efficiency, performance ratio (PR), gained output ratio (GOR), permeate flux, and specific energy consumption (SEC). The difference in partial vapor pressure, as a result of the temperature gradient across the membrane, is the main driving force for water vapor transport across the hydrophobic membrane. The temperature gradient, which is function of bulk and transmembrane temperatures, is affected by temperature polarization at both feed and permeate sides $[53,54,57,58,65,88,89]$. Temperature polarization during MD process increases with the mass transfer coefficient of the hydrophobic membrane. The same effect is observed when the inlet feed and permeate temperature difference increase, or when both feed and permeate flow rates decrease. The partial vapor flux increases exponentially when the transmembrane temperature increases beyond $40^{\circ} \mathrm{C}$. However, if the feed or permeate temperatures lie below 
$40^{\circ} \mathrm{C}$, the corresponding partial vapor pressure does not change considerably with temperature, although it is worth mentioning that a feed temperature of $40^{\circ} \mathrm{C}$ is inappropriate for the MD process. To reduce the effect of temperature polarization on MD performance, module channels are often filled with spacers to promote turbulence [48, 65, 88, 90-92]. Indeed, spacers increase fluid flow instability and can create complex currents in the laminar regime, thus enhancing momentum, heat and mass transfer [93]. The effect of spacers depends on their design. Their contribution to the enhancement of convection heat transfer can be represented by the so-called spacer factor, which is a function of several characteristics including filament's thickness, spacer's thickness and spacer's voidage. The channel hydraulic diameter and the feed flow direction (hydrodynamic angle) play an important role as well [88]. The spacer factor, if greater than 1 , enhances the convection heat transfer coefficient and reduces temperature polarization [94].

Various MD configurations have been suggested to enhance system performance in terms of water production and thermal efficiency. Depending on the design of the permeate side, the process is called Direct Contact MD (DCMD) if the permeate is in direct contact with the membrane. Even though DCMD exhibits the highest conduction heat losses because the hot feed and cold permeate sides are in the direct contact with the membrane, it is characterized by its simple module configuration and remains appropriate for lab-scale experiments [51, 57, 9597]. Departing from DCMD module design, advanced configurations have been designed including Air Gap MD (AGMD), Sweeping Gas MD (SGMD), vacuum MD (VMD), material gap MD (MGMD) [44] and conductive gap MD (CGMD) [41]. All configurations have been suggested to mitigate conduction heat loss, except CGMD, which uses a conductive material between the membrane and the condensing surface to offer a possibly higher overall GOR. In AGMD and MGMD, the thermal insulator (air or other material including water, respectively), separates feed and permeate sides of the MD module. In the SGMD variant, gas flows in the gap, while in VMD the coolant flow is replaced by vacuum to enhance the driving force, thus vapor flux. The MD configurations can also be categorized with respect to the way water vapor is condensed inside the module. While in the DCMD system water vapor condenses immediately into the coolant, water vapor generated in the AGMD process is condensed on a cooling plate with no mixing between permeate and coolant. However, in MGMD, water vapor is condensed within the insulator while during VMD an external condenser collects the permeate. Recently, the VMD vacuum system used to increase water vapor flux has been associated to other MD variants, such as vacuum enhanced DCMD where vacuum is applied 
to the coolant loop at the permeate tank [98]. The vacuum enhanced AGMD process was also suggested to remove the non-condensable gases in the air-gap side to further increase the driving force of MD process [46]. There is only one study that reports a different feed side configuration where the effect of temperature polarization was decoupled from the membrane mass transfer coefficient by preventing the liquid feed from contacting the membrane surface of a VMD system [42]. The authors reported that with this flashed-feed configuration, a vapor water flux of $9 \mathrm{~L} / \mathrm{h} \cdot \mathrm{m}^{2}$ and $40 \mathrm{~L} / \mathrm{h} \cdot \mathrm{m}^{2}$ could be achieved with a transmembrane temperature difference of $5{ }^{\circ} \mathrm{C}$ and $10{ }^{\circ} \mathrm{C}$, respectively, by eliminating the temperature polarization effect.

Extensive research focused on membrane module types such as flat sheet, hollow fiber and spiral wound. Flat sheet module $[51,59,99-101]$ is the simplest configuration in which the hydrophobic membrane is confined between two metal or plastic frames. It is often used at the laboratory scale for its simple design and handling as well as easy cleaning. However, the effective membrane area of the flat sheet module is relatively low compared to a hollow fiber configuration. The hollow fiber module [76, 102-106] consists of a set of hollow fibers sealed into a shell tube. Although this configuration requires particular sealing and proper techniques to ensure its long-term high durability against thermal expansion, it has the advantage of high fiber packing density (ratio of effective area of membrane to the packing volume) so that membrane effective area is maximized. However, when membrane fouling occurs, cleaning and fibers replacement remains tedious. The hollow fiber module can operate in two different modes with respect to coolant and feed flows, namely, inside-out and outside-in. In the insideout configuration, feed flows in the lumen side of the fibers and coolant flows in the shell side, so that permeate is collected on the shell side. Oppositely, in the outside-in configuration, the feed flows inside the shell while the permeate flows in the lumen side where it is collected. Finally, the spiral wound module [17, 25, 107-109] consists of a number of stacked flat sheet membranes and spacers, and a perforated central collecting tube. This module design offers a high effective area to volume ratio. Although its packing density is usually less than that of hollow fiber module, the spiral wound module is often employed in conventional desalination process such as RO due to its good balance between packing density, operation handling, fouling control and permeation rate.

Extensive literature related to MD energy analysis is available. However, as reported in a review by Khayet [110] for different MD configurations as well as hybrids, SEC of the MD process spans over 3 orders of magnitude ( 1 to $9000 \mathrm{kWh} / \mathrm{m}^{3}$ ) with no established calculation methodology. It is also worth mentioning that most investigations pertain to desalination and 
analysis of other water treatment processes are seldom found. With regards to desalination, a thermodynamics and energy analysis by Lienhard et al. [111] shows that the MD module represents the major source of entropy generation due to mass transfer resistance across the membrane and to a lesser extent conduction losses. On the other hand, thermal desalination processes (MSF and MED) exhibit an energy consumption in the range of $10 \sim 120 \mathrm{kWh} / \mathrm{m}^{3}$ [110, 112] while RO consumes only $3 \sim 10 \mathrm{kWh} / \mathrm{m}^{3}$ [113]. Therefore, for MD to be economically viable, a reduction of the specific energy consumption is required. Improvements can be brought with the fabrication and commercialization of highly-permeable hydrophobic membranes, as well as optimization of process operating conditions. Nevertheless, MD has a high potential and can eventually replace conventional desalination processes, especially for niche applications, because it can be economically operated using low-grade waste heat or renewable energy resources such as solar and geothermal energies [110, 112]. Moreover, as regulations related to waste heat emissions are getting stricter worldwide, there is a need to develop more efficient routes to utilize low-grade waste heat. Unlike high temperature steams $\left(\sim 110^{\circ} \mathrm{C}\right)$, which present a potential for high energy recovery using efficient boilers and heat pumps, low temperature waste heat which is usually available at a lower temperature has insufficient propensity for energy recovery. In this case, low grade waste heat is cooled down before it is exhausted in compliance with regulations. As such, MD implementation using lowgrade is twofold, as it produces fresh water while reducing the cost of cooling utilities.

\section{HYBRIDIZATION OF MD WITH CONVENTIONAL PROCESSES}

\subsection{RO-MD hybrid}

$\mathrm{RO}$ is a well-established highly efficient desalination process for freshwater production. Nevertheless, it is not capable of treating concentrated brines due to physical limitations imposed by high osmotic pressure values. Thereby, water recovery ratio in $\mathrm{RO}$ is limited to a maximum of $\sim 50 \%$ (although it can practically reach $60 \%$ if a second stage driven with a very high applied pressure is used). In order to overcome this limitation and achieve higher freshwater recovery, the process can be integrated with MD (see Fig. 1) which is weakly affected by high salt concentrations [109, 114-117]. However, due to chemical pretreatment of RO brine concentrate, chemical species such as anti-scalants and chemical cleaning agents can affect MD process scaling and cause membrane wetting. Due to these limitations, scaling and wetting extensive analyses were conducted with RO brine as feed solution for MD process [33, 118-130]. 


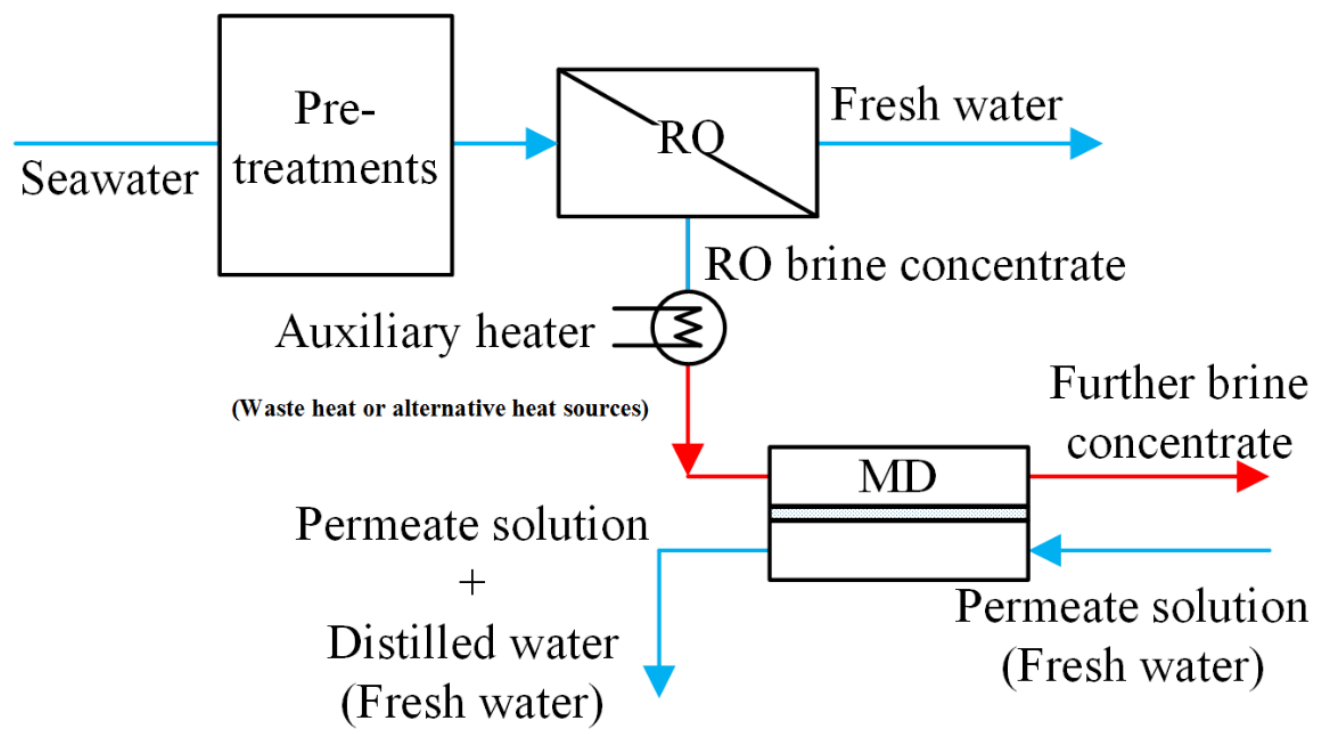

Fig. 1 Schematic of basic concept of RO-MD hybrid system.

Possible integration of RO with MD was suggested and tested by Drioli et al. [117] for high water recovery ratio. The experiment, using seawater with salt concentration of $45 \mathrm{~g} / \mathrm{L}$, runs at a temperature of $25^{\circ} \mathrm{C}$ to increase water recovery from $40 \%$ (only $\mathrm{RO}$ ) to $87.6 \%$ (RO+MD). The RO brine discharge was heated up then fed to MD, which was operated under an inlet feed and permeate temperatures of $35^{\circ} \mathrm{C}$ and $15^{\circ} \mathrm{C}$ respectively, and feed and permeate flow rate of $5 \mathrm{~L} / \mathrm{min}$ and $3.33 \mathrm{~L} / \mathrm{min}$, respectively. During MD, the initial water vapor flux was $2.4 \mathrm{~kg} / \mathrm{m}^{2} \mathrm{~h}$ then dropped to $1.4 \mathrm{~kg} / \mathrm{m}^{2} \mathrm{~h}$ as the brine concentration (MD feed) increases towards saturation (5.33 M). Additionally, the authors presented the advantages of RO-MD hybrid such as the reduction of environmental impact as a result of the reduction of discharge and the possibility of by-product recovery from the highly concentrated brine. RO-VMD hybrid was also shown to enhance water recovery from a feed with high salt concentration $(300 \mathrm{~g} / \mathrm{L})$ [33]. Long-term operation was performed at various operating conditions such as inlet feed temperature, Reynold number, and vacuum pressure. The authors claim $89 \%$ of global water recovery by hybridizing VMD and RO. However, the vapor flux decreases from an initial value of $17 \mathrm{~L} / \mathrm{m}^{2} \mathrm{~h}$ to $7 \mathrm{~L} / \mathrm{m}^{2} \mathrm{~h}$ during the last steps of the process, due to the increase of brine salt concentration from $64 \mathrm{~g} / \mathrm{L}$ to $300 \mathrm{~g} / \mathrm{L}$, respectively. Although scaling by precipitation of $\mathrm{CaSO}_{4}$ and $\mathrm{CaCO}_{3}$ crystallization was observed on the membrane surface, the authors claim a low impact since large areas remained free of visible scaling. On the other hand, when a synthetic solution of pH8 is used (including $\mathrm{NaCl}(35 \mathrm{k} \mathrm{ppm}), \mathrm{CaSO}_{4}(1.9 \mathrm{k} \mathrm{ppm})$ and $\mathrm{CaCO}_{3}(140 \mathrm{ppm})$ ), Lee et al. [131] reported that $\mathrm{CaSO}_{4}$ scaling on the membrane has a significant impact on the flux decline 
when the volume concentration factor is at the high value of 4.45. In order to mitigate scaling while still enhancing water recovery, Qu et al. [123] suggested the integration of accelerated precipitation softening (APS) with MD for high recovery desalination of RO brine. The crystallization of brine was accelerated during feed pretreatment by adding $5 \mathrm{~g} / \mathrm{L}$ of calcite at an agitating rate of $200 \mathrm{round} / \mathrm{min}$. After APS, concentration of $\mathrm{Ca}^{2+}$ decreased by $92 \%$. As a result, only $20 \%$ of flux decline was observed after $300 \mathrm{~h}$ of operation due to the alleviation of $\mathrm{CaCO}_{3}$ and $\mathrm{CaSO}_{4}$ crystal formation on the membrane surface. Duong et al. [130] studied the scaling control in MD process during desalination of coal seam gas (CSG) brine. Although the increase in feed salinity did not lead to a significant water flux decline, the permeation of vaporized $\mathrm{CO}_{2}$ through membrane pores competed with water vapor transfer causing a gradual decrease. At a feed temperature of $35^{\circ} \mathrm{C}$, the permeate flux was maintained at $10 \mathrm{~L} / \mathrm{m}^{2} \mathrm{~h}$ with $80 \%$ increase in water recovery ratio without any signs of membrane scaling. Interestingly, the authors also reported that scale mitigation agents present in RO brine did not alter the hydrophobicity of the membrane. In a follow up study, Duong et al. [109] designed a pilotscale system for the treatment of CSG produced water by a combination of UF/RO and AGMD processes using solar energy as a heat source. $80 \%$ of water recovery was observed when adding anti-scalant to CSG produced water and using small temperature difference between the feed and cold sides of the AGMD system. The reported specific thermal energy consumption and specific electrical energy consumption were $250 \mathrm{kWh} / \mathrm{m}^{3}$ and $1.1 \mathrm{kWh} / \mathrm{m}^{3}$, respectively.

In order to mitigate organic fouling of MD membranes in RO-MD hybrids, Naidu et al. [119] pretreated RO wastewater concentrate with granular activated carbon. This enabled removal of micro-pollutants with particle size ranging between $425 \mu \mathrm{m}$ and $600 \mu \mathrm{m}$, resulting in vapor flux enhancement across the MD membrane.

Current studies on RO-MD hybrids do not adopt any heat recovery scheme in the system. Therefore, they will result in higher thermal specific energy consumption compared to other conventional desalination processes. However, if proper heat recovery scheme is utilized, the thermal energy consumption could be reduced to levels observed in conventional thermal desalination processes. Moreover, reported water recovery of RO-MD hybrids could exceed $80 \%$ [109], which is twice as much as conventional RO system recovery. This higher water recovery rate is a viable path towards achieving zero liquid discharge policy by reducing the burden of the crystallization process and ultimately alleviate the thermal cost. 


\subsection{BR-MD hybrid}

Numerous research efforts have been dedicated to the evaluation of BR-MD hybrid process. Various applications were considered including the intensification of biological treatment of industrial effluents [132], or wastewaters of different origins [133-142], as well as for the removal of volatile fermentation by-products in the food industry [143-148]. In a typical BRMD hybrid, the MD process is integrated with the thermophilic bioprocess. During MD separation, only volatile compounds cross the membrane, leading to rejection of nonvolatile feed components such as microorganisms, organic compounds and salts. In turn, MD unused heat is employed to achieve biodegradation of wastewater contaminants in BR [149]. Moreover, application of waste heat or solar energy could potentially reduce the total cost of BR-MD, making it economically viable compared to conventional wastewater reclamation. A range of different BR-MD configurations has been suggested, based on a direct submersion of the MD membrane into BR [133, 142, 144, 146, 147, 150-153] (Fig. 2) or combining MD and BR modules to allow continuous feed recirculation [135, 137-141, 143, 145] (Fig. 3). An integrated FOBR-MD (Fig. 4) has also been suggested [154-158]. In the FOBR-MD system, the MD module is used for regeneration of the draw solution (DS). The DCMD configuration with flat sheet membranes was utilized in most studies [133, 135-141, 150, 153-158], although tubular- [142] and capillary-based DCMD modules were also reported [143, 144, 146, 147, $151,152,159]$.

The BR-MD process has a high capacity in removing organic fraction from wastewater. Depending on the feed type and operating conditions, the chemical oxygen demand (COD) and total organic carbon (TOC) removals could reach as high as 90-99.9\% [133, 136, 137]. Integrated BR-MD process was proven effective especially in eliminating emerging water contaminants, which are hard to remove by conventional wastewater treatment processes. Song et al. [140] reported that integration of anaerobic BR with MD increased removal of 26 different pharmaceutical compounds from $15-25 \%$ by sole BR to above $76 \%$ due to additional rejection by MD. Similarly, Wijekoon et al. [141] achieved 95\% removal of a range of trace organic micro-pollutants which are recalcitrant to biological treatment due to presence of electronwithdrawing functional groups. Integration of $\mathrm{MD}$ with enzymatic BR allowed removing up to $90 \%$ of thirty different pharmaceuticals, personal care products, steroids and pesticides [138, 139]. Furthermore, the addition of redox-mediators enhances the enzymatic activity of laccase and reduced toxicity of MD permeate to levels below detection limits. Integration of MD module into BR-MD hybrid also enhanced removal of nutrients, which are biodegraded in BR. 
For example, Kim et al. [136] reported complete phosphorous removal from domestic wastewater in the anaerobic moving bed biofilm BR-MD. A significant reduction of TDS, nitrates $\left(\mathrm{NO}_{3}-\mathrm{N}\right)$ and ammonia $\left(\mathrm{NH}_{4}-\mathrm{N}\right)$ concentrations below tolerated limits was achieved by Khaing et al. [132]. Despite the high efficiency of the BR-MD process in reducing concentration of non-volatile wastewater constituents, the rejection of volatile organic contaminants reveals a lower efficiency. Song et al. [140] demonstrated a 90\% removal of $\mathrm{NH}_{4}{ }^{+}$within 20 days of BR-MD operation. However, removal efficiency gradually decreased to $60 \%$ on day 30 due to $\mathrm{NH}_{4}{ }^{+}$conversion to $\mathrm{NH}_{3}$, which is highly volatile and can cross the MD membrane. The observed effect is worsened with an increase of the feed temperature due to a corresponding increase in the vapor pressure. Indeed, Liu et al. [135] reported a decrease in $\mathrm{COD}_{\mathrm{Cr}}$ removal from $98.3 \%$ to $92.4 \%$ when the feed water temperature was increased from $55^{\circ} \mathrm{C}$ to $93^{\circ} \mathrm{C}$.

In general, vapor fluxes achieved by BR-MD hybrid are lower than those achieved by stand-alone MD processes [133]. This is attributed to induced membrane fouling and subsequent wetting due to high organic load of the reclaimed feed water. The fouling layer which is formed on the membrane surface, increases mass and heat transfer resistances which hamper vapor diffusion across the membrane [149]. As a result, permeate flux and process efficiency is reduced. In a study by Phattaranawik et al. [142], MD membranes were directly immersed into activated sludge BR. The temperatures inside the BR-MD were maintained at $58.5{ }^{\circ} \mathrm{C}$ and $45{ }^{\circ} \mathrm{C}$ for cold and hot sides, respectively, corresponding to vapor fluxes in the range of 2 to $5 \mathrm{~L} / \mathrm{m}^{2} \mathrm{~h}$. Khaing et al. [132] evaluated the BR-MD feasibility to treat petrochemical wastewater. The system was ran continuously for 105 days sustaining a permeate flux above $5.5 \mathrm{~L} / \mathrm{m}^{2} \mathrm{~h}$. The presence of biomass in the BR-MD feed may accelerate membrane fouling by building up a biofilm layer on the membrane surface. Goh et al. [134] showed that depending on the sludge hydrophilicity and distribution of the pores in the biofouling layer, the vapor pressure across the membrane reduces by $20-30 \%$ causing up to $60 \%$ decrease in MD permeate flux. An increase of the organic load of the feed water is another limiting factor which not only reduces vapor flux across membrane but also promotes diffusion of organic matter to the permeate side. The effect of a biodegradation process on membrane fouling and permeate flux was investigated by Goh et al. [133]. Authors showed that lowering organic and nutrient loads not only delays membrane wetting by 1.7-3.6 times, but extends MD operations without recourse to membrane cleaning. As a result, a stable permeate flux was maintained at $6.8 \mathrm{~L} / \mathrm{m}^{2} \mathrm{~h}$ for more than 13 days. The effect of membrane characteristics such as 
pore size as well as the effect of operating conditions including temperature difference across the membrane and cross-flow velocity have been extensively studied by Liu et al. [135]. Interestingly, the authors concluded that optimization of BR-MD systems can lead to process efficiency as high as $99 \%$ while maintaining minimal membrane fouling. Zhang et al. [153] analyzed the thermophilic microbial community composition of the submerged BR-MD. The authors concluded that BR-MD is comprised of bacterial community and eukaryotic communities which resisted changes in operating parameters.

Energy analysis through full scale experiments of MBR process revealed that aeration using air blowers contributes between $50 \%$ and $88 \%$ of its total SEC [160, 161]. Although, total energy requirements remain low compared to other techniques and barely exceed $1 \mathrm{kWh} / \mathrm{m}^{3}$. Therefore, hybridization of BR with MD is expected to increase the process SEC. However, it is worth recalling that the hybrid system is able to reject chemical species hardly removed by other processes. Nevertheless, BR-MD hybrids could potentially be applied in the areas where hot wastewater and waste heat are generated. For example, although aerobic thermophilic BR requires high aeration energy input, its combination with the MD process could make it more economically feasible due to its ability to utilize the hot influent $[160,161]$.

Combination of FOBR and MD systems allowed re-concentration of DS and produced high quality effluent water after rejection of non-volatile organics and salts by the MD subsystem. Morrow et al. [154] designed and tested aerobic/anoxic BR-MD for portable water reuse where FO and MD processes were operated simultaneously and fed from one tank so that the FO DS also served as MD feed solution. The authors reported high removal of carbon (98\% as COD) and nitrogen $\left(90.2 \%\right.$ of $\left.\mathrm{NH}_{4}{ }^{+}-\mathrm{N}\right)$ species from wastewater. Moreover, the authors also suggested that reconcentration of the draw solution with the waste-heat driven MD will reduce the overall electrical energy requirement of the process. Shahzad et al. [155] optimized the FOBR-MD system with respect to different organic and inorganic DS. Integration of the MD module allowed achieving high recovery of DS while rejecting more than $99 \%$ of total dissolved solids (TDS) and organic contaminants. Siddique et al. [158] demonstrated that organic DS, re-concentrated in the MD module, were capable of mitigating salinity build-up in the BR. A novel multi-barrier system comprised of attached growth biofilm integrated with FOBR and MD was suggested by Nguyen et al. [156]. This system demonstrated high removal of $\mathrm{NH}_{4}-\mathrm{N}(99.94 \%)$ and $\mathrm{PO}_{4}-\mathrm{P}(99.73 \%)$ compounds as well as reduced membrane fouling during 60 days of operation. Recently, Luo et al. [157] reported a combined FOBR-MD system aimed at concurrent desalination and wastewater treatment. The system achieved over $90 \%$ 
removal of thirty trace organic compounds, although membrane fouling by humic and protein like substances was observed.

Enzymatic BR-MD systems have also been applied in food industry for separation of ethanol and other volatile organic compounds formed during fermentation of sucrose [143], lactose [144], sugarcane juice [145] and whey [146]. The advantage of such systems over conventional batch fermentation systems is the continuous withdrawal of fermented products by means of MD so that biomass conversion is accelerated. Indeed, Gryta et al. [143] reported an increase in the production rate of ethanol from $2.5-4(\mathrm{gEtOH}) / \mathrm{dm}^{3} \mathrm{~h}$ in batch fermentation compared to 0.8-2 (gEtOH)/dm ${ }^{3} \mathrm{~h}$ achieved in BR-MD system. In a follow-up study [147], the authors investigated the effect of biofouling during MD of fermented glycerol solutions. It was found that membranes did not exhibit signs of wettability and high degree of separation was achieved over $1000 \mathrm{~h}$ of operation. In another process variant, Pal et al. [148] reported 98\% of ethanol recovery in a solar-driven DCMD process installed downstream of the integrated fermenter system. It is important to highlight that during conventional ethanol production; most of the energy is spent during the distillation step due to low ethanol content in a broth solution (5-12\%) [152]. As such, those higher ethanol pre-concentration rates observed in enzymatic BR-MD system process, as compared to regular distillation process, would lead to significant energy savings [151]. Another major advantage of an industrial implementation of the enzymatic BR-MD process lies in the simplification or even exclusion of a range of downstream processes with high energy consumption including centrifugation, distillation, or dehydration. As a result, the energy consumption can be reduced from $112 \mathrm{kwh} / \mathrm{m}^{3}$ in conventional system to as low as $27 \mathrm{kWh} / \mathrm{m}^{3}$ in BR-MD system leading to $30 \%$ total cost reduction [145]. 


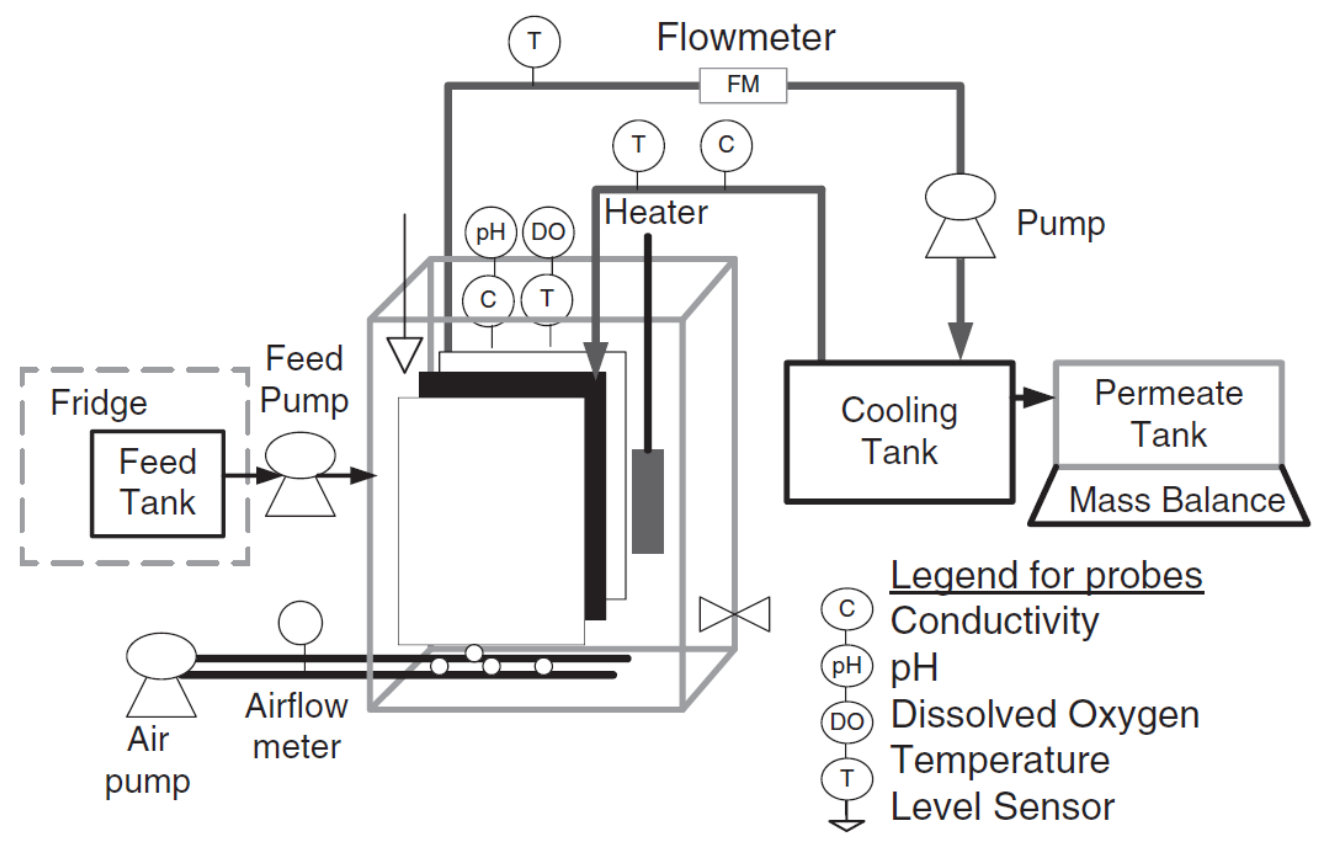

Fig. 2 Schematic of submerged BR-MD system [133].

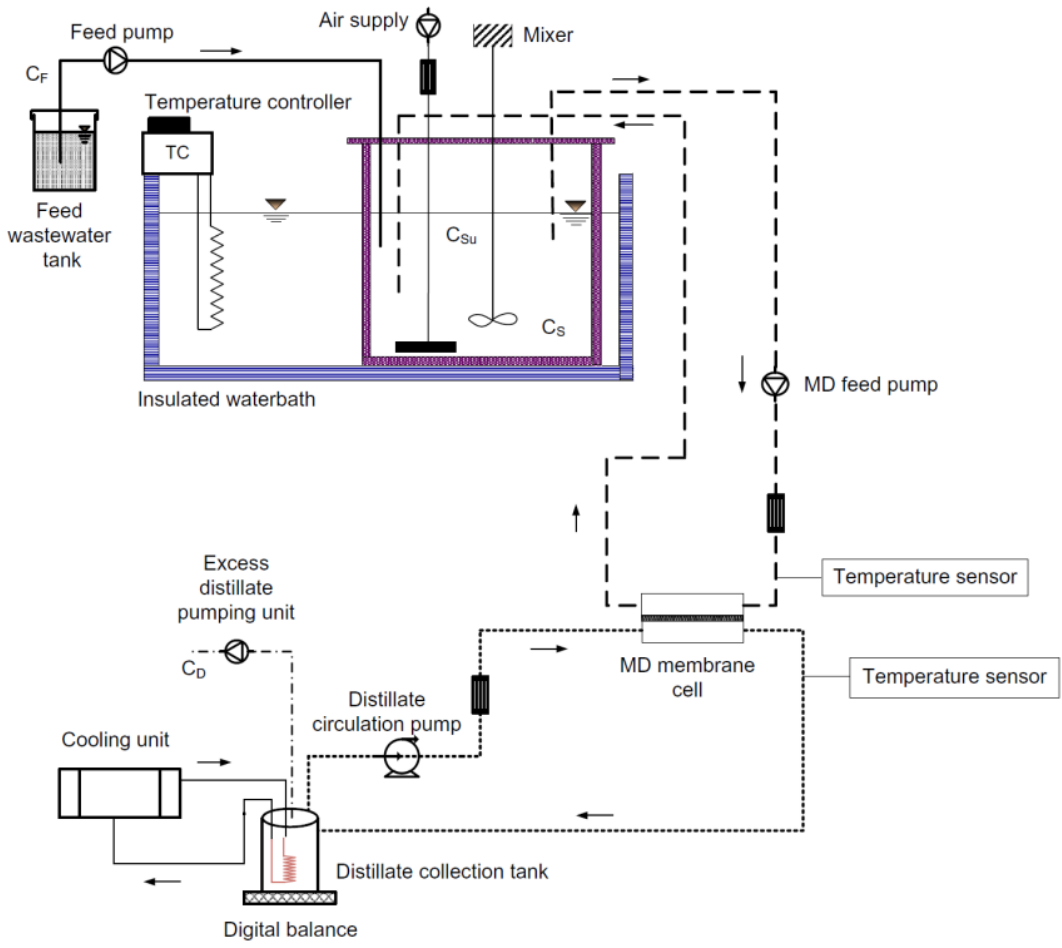

Fig. 3 Schematic of the coupled BR-MD system [141]. 




Fig. 4 Schematic of the FOBR-MD [154] systems.

The literature regarding long-term effects of BR-MD operations in terms of membrane fouling and permeate flux stability is scarce. Most of the reported studies employed short-term BR-MD runs and only few have investigated extended operations (12 h [139], 3 days [135, 137], 3.5 days [145], 6.2 days [136], 25 days [133, 155, 158], 35 days [141], 40 days [157] 50 days [154], 60 days [125] and 105 days [150]).

\section{3. $M V C-M D$ hybrid}

A first publication regarding MVC-MD integration is the US patent filed by Andrew Shapiro under General Electric Co in 2010 [162]. In MVC-MD, a latent heat of condensation is converted into latent heat of vaporization by compressing MD-generated steam in the MVC module. During the compression process, the water vapor would release the heat, which is further used to heat feed water flowing to the MD module. The author suggested that coupling MD and MVC processes would intensify MD by bringing the mass flow of the condensing stream and the input feed stream to the same order of magnitude. In a follow-up patent, Pereira et al. [163] improved the performance of the MVC-MD hybrid by adding a steam expander positioned downstream of the vapor compressor. The steam expander will produce an expanded output flow from a high pressure steam flow. As a result, both flows will serve as a flow of intermediate pressure to the MD module. Swaminathan et al. [164] replaced the heat exchanger with the MD module during the MVC seawater desalination (Fig. 5). Numerical simulation of the MVC-MD process as a function of the MD type and operating conditions revealed a $6 \%$ decrease in the cost of produced water compared to stand-alone MVC. The savings are expected to further increase with the increase in feed temperature and decrease in recovery ratio and capital costs. The AGMD and CGMD were found the most effective MD 
configurations with the highest savings. Given the advantages of MVC-MD hybrid over the MVC system, further research is required to evaluate its efficiency in real desalination conditions using seawater and rejected brines.

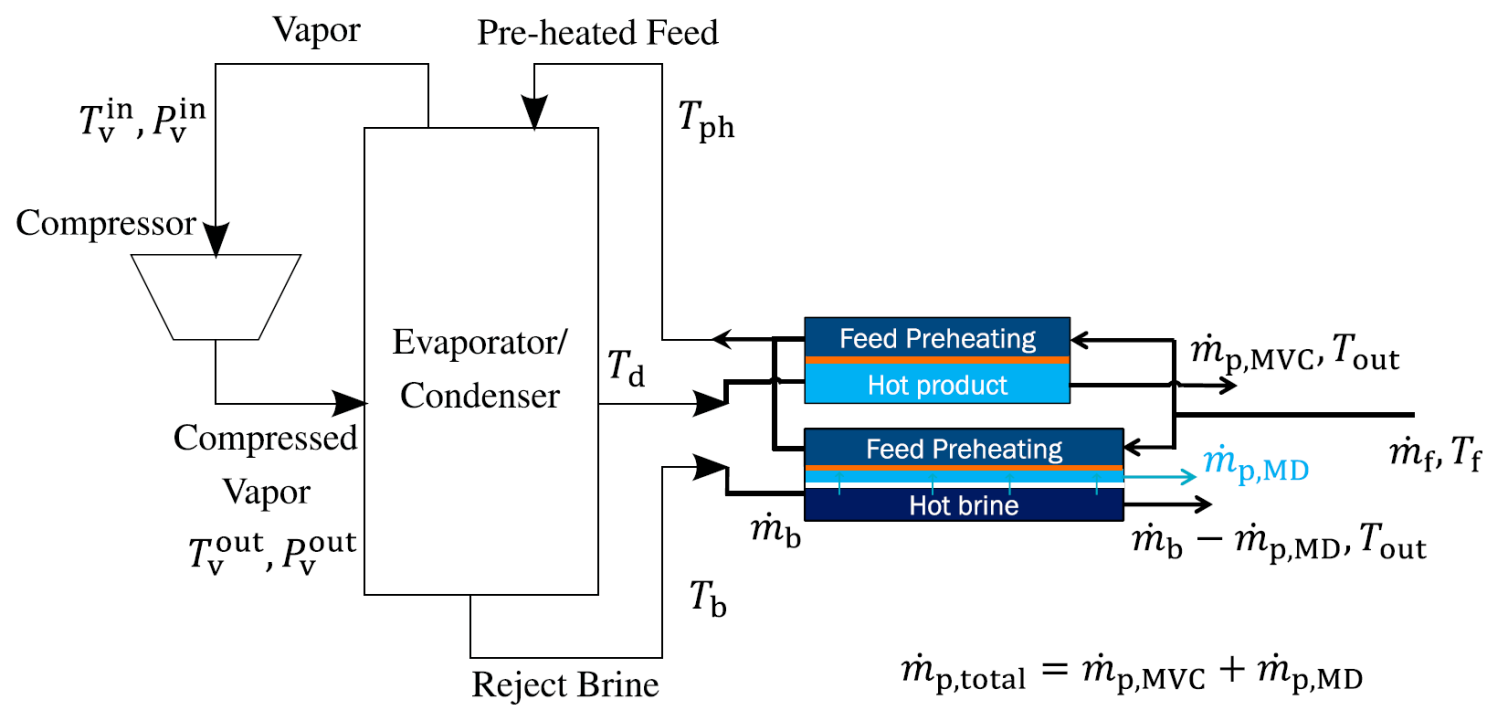

Fig. 5 Schematic of the MVC-MD system [164].

\subsection{MED/MSF-MD hybrid}

The conventional thermal desalination processes, namely MED and MSF, are predominant processes for freshwater production in arid areas of Middle East and Northern Africa [165]. Although energy consumption of these processes is extremely high, waste heat emitted during operations can be recovered. Rejected brines from both MED and MSF are released at high temperatures and can serve as influents to the MD process. As such, combination of conventional distillation and MD in one process train is expected to not only recover the waste heat but also increase the cost-efficiency of MD desalination as well as enhance freshwater production in the thermal desalination plant. De Andres et al. [166] designed a combined system which included one-stage MED and DCMD modules. In this system, the rejected brine from the MED process was supplied to the DCMD module at temperatures ranging from $40^{\circ} \mathrm{C}$ to $80^{\circ} \mathrm{C}$ and the temperature at the cooling side of the DCMD module was maintained at $20^{\circ} \mathrm{C}$. The authors found out that production of distilled water was practically independent of flow rates in both DCMD compartments. The integration of DCMD with MED improved water production of MED system by 7.5\%. Minier-Matar et al. [167] evaluated the performance of MD module by using brine from actual full-scale MSF desalination plant. In this study, two pilot MD modules utilizing multi-effect VMD and AGMD processes were placed side-by-side 
and operated in parallel on the premises of the MSF plant. Both MD systems were tested with respect to hot brine temperature and flow rate. The effect of vacuum pressure was also investigated for the VMD system. In optimal conditions, the multi-effect VMD outperformed AGMD by achieving higher permeate flux and contaminants rejection $\left(6.2 \mathrm{~L} / \mathrm{m}^{2} \mathrm{~h}\right.$ and $99.9 \%$, and $2.5 \mathrm{~L} / \mathrm{m}^{2} \mathrm{~h}$ and $98.9 \%$, respectively). Brine pretreatment is a critical issue in combined MDthermal desalination hybrids due to presence of chemicals (such as antifoaming agents causing pore wetting) which can lead to membrane loss of efficiency or failure. Bamufleh et al. [168] suggested an extension of MED-MD capacity by thermal integration with adjacent industrial plants for better heat recovery (Fig. 6). The authors developed and solved a superstructurebased optimization formulation to determine important design and operating parameters to reach a combined production capacity of 3850 tons/day. Depending on the cost of fuel, whether waste heat from the industrial facility was used, final cost of the desalinated water varied between $\$ 0.61 / \mathrm{m}^{3}$ and $\$ 1.65 / \mathrm{m}^{3}$. González-Bravo et al. [169] evaluated different integrated desalination systems to define the best design which would allow to reduce energy and water loads. The authors showed that MD desalination systems coupled with MED or MSF processes present the highest economic and environmental benefits compared to MD systems coupled with other desalination processes. The MED-MD system was more effective in terms of total annual profit compared to MSF-MD system with a yearly cost of 69.577 MM\$/year comprising $88.6 \%$ and $7.09 \%$ of energy and desalination costs, respectively. In summary, available literature related to MED/MSF-MD processes is scarce and additional studies are required to address long-term effect of membrane fouling and wetting, concentration and temperature polarization as well as heat/energy consumption in order to make this technology preferable and cost-efficient for end-users. 


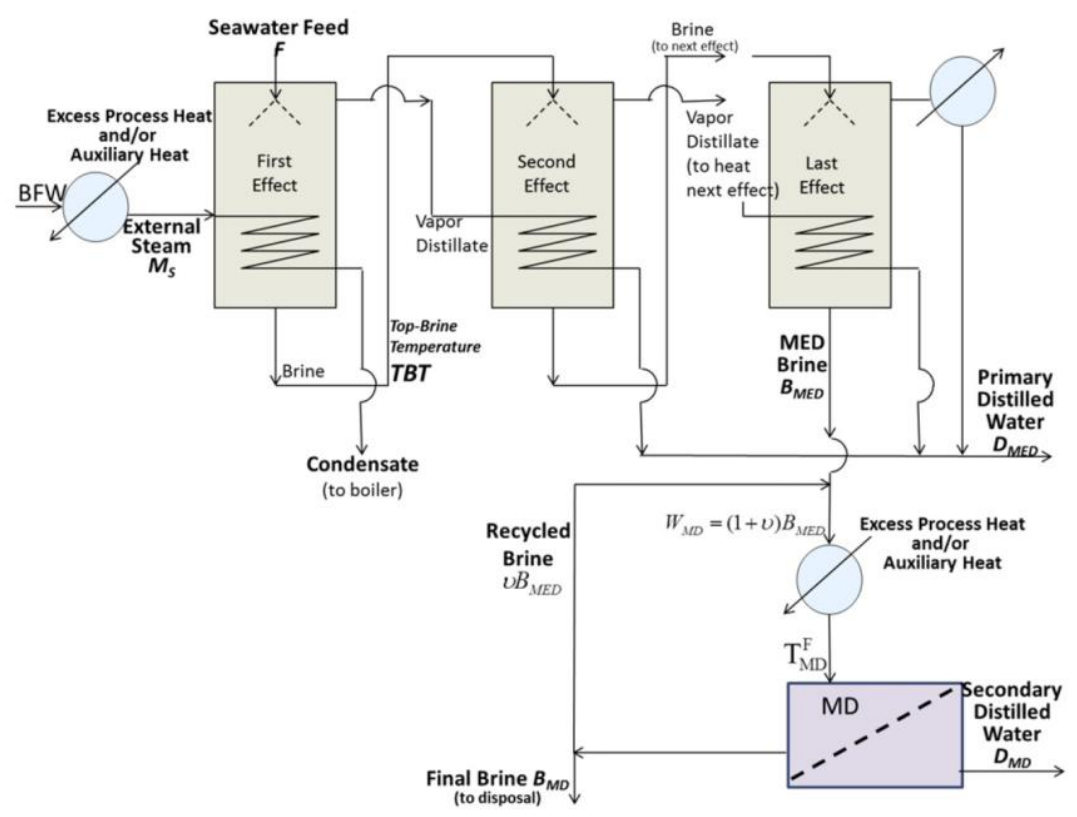

Fig. 6 Schematic of the MED-MD system.

\subsection{MDC-MD hybrid}

Currently, zero liquid discharge (ZLD), which is based on complete elimination of brine disposal to aquatic environments and reclaiming treated water and solid waste, is becoming a necessary waste management practice due to its ability to reduce air and water pollution as well as emission of greenhouse gases [170]. In practice, ZLD is achieved through thermal evaporation of liquid wastes in full-scale concentrators and crystallizers. However, thermal evaporation technologies are characterized by high energy consumption with $20-22 \mathrm{kWh} / \mathrm{m}^{3}$ and 52-66 $\mathrm{kWh} / \mathrm{m}^{3}$ of treated water for concentrator and crystallizer, respectively [171]. Therefore, there is an increasing need for alternative technologies to not only comply with stringent discharge standards, but also reduce the overall cost of solid waste treatment. In this regard, MD-crystallization (MDC) process attracts attention for its ability to combine freshwater production and extraction of valuable products in a single treatment train. Moreover, MD process remains relatively efficient in moderate range of temperatures, as its specific energy consumption is lower $\left(15-20 \mathrm{kWh} / \mathrm{m}^{3}\right)$ [172] to that of conventional crystallization process $\left(\sim 30 \mathrm{kWh} / \mathrm{m}^{3}\right)$ which has to be operated at high temperatures [173].

The potential of MDC in treating different types of water including RO brine [174], seawater [175], shale gas produced water [176], synthetic saline waters [177-182] has been thoroughly investigated. The process has a high potential in recovering $\mathrm{NaCl}[178,183], \mathrm{Li}$ [179], $\mathrm{Na}_{2} \mathrm{SO}_{4}$ [184] and other solids [175]. A synergetic effect of MD and crystallization would not only enhance the recovery of solids, but would sustain production flux by reducing 
membrane scaling/wetting due to continuous withdrawal of scale-causing compounds [176, 182]. The ability of MD to operate at high salt concentrations is another advantage of MDC because it allows treating highly saline brines without compromising flux significantly. Recently, Kim et al. [176] investigated the applicability of MDC process for the conditioning of shale gas produced water with a TDS as high as $150 \mathrm{~g} / \mathrm{L}$. An initial permeate flux of around $35 \mathrm{~L} / \mathrm{m}^{2} \mathrm{~h}$ was achieved, followed by a fast decrease due to membrane fouling by oil and salts present in the feed water. However, membrane fouling was significantly slowed down when a crystallizer was assembled downstream of the MD unit to remove barium and calcium-based salts. In this case, water recovery reached $62.5 \%$ compared to only $37.5 \%$ for stand-alone MD. Quist-Jensen et al. [180] compared three types of MD processes, DCMD, osmotic MD (OMD) and VMD combined with crystallization for their efficiency in treating highly concentrated $\mathrm{LiCl}$ solutions. The solubility limit of $\mathrm{LiCl}$ is very high $(14 \mathrm{M})$ which makes crystallization difficult to achieve. The authors showed that DCMD and OMD processes were able to concentrate $\mathrm{LiCl}$ solutions to only $7 \mathrm{M}$ and $10 \mathrm{M}$, respectively, due to osmotic pressure build up. However, application of VMD process brought $\mathrm{LiCl}$ concentration to its saturation level, which enabled further crystallization. The observed effect was attributed to reduced temperature polarization and reduced resistance to vapor transport in VMD. Importantly, the cost of $\mathrm{LiCl}$ production was estimated at a level of $\$ 2.182 / \mathrm{kg}$, which is comparable to the cost of conventional $\mathrm{LiCl}$ production from salt lake brines $(\$ 2 / \mathrm{kg})$.

Since highly saline feed waters are predominantly used as MDC feeds, it is important to optimize MDC operating conditions to achieve high freshwater and solids recovery as well as minimize crystal deposition within the MD module and pipeline network. Chen et al. [183] employed the orthogonal fraction factorial experimental design to address this issue. The authors concluded that flow rate rather than temperature are the primary factors controlling MDC performance. Shin and Sohn [182] studied crystallization mechanisms in order to gain better control over scale formation. According to authors, flow rate regime determines fouling potential by surface or bulk crystallization, and the lowest membrane fouling was observed at intermediate flow rates $(\sim 1000 \mathrm{~mL} / \mathrm{min})$. Edwie and Chung [181] reported that when the feed temperature was increased from $40^{\circ} \mathrm{C}$ to $60^{\circ} \mathrm{C}$, a rapid flux decline due to salt oversaturation at the membrane boundary layer was observed. The authors estimated the critical feed fluxes required to achieve stable MDC operation while keeping salt concentration below the saturation level. When MDC system was operated in the optimal conditions at $70{ }^{\circ} \mathrm{C}$, the yield of $\mathrm{NaCl}$ was $34 \mathrm{~kg} / \mathrm{m}^{3}$ as compared to only $7.5 \mathrm{~kg} / \mathrm{m}^{3}$ at $40{ }^{\circ} \mathrm{C}$. In another contribution, Creusen 
et al. [175] optimized MD performance and reduced crystallization at the membrane surface by seeding the feed water with salt crystals. However, while addition of $\mathrm{CaCO}_{3}$ crystals enhanced vapor flux by promoting $\mathrm{CaCO}_{3}$ crystallization in the bulk, seeding with $\mathrm{NaCl}$ did not improve vapor flux. The economical evaluation of the suggested MDC process for seawater treatment revealed that possible energy and investment costs would comprise approximately $\$ 0.74$ and $\$ 0.50$ per $\mathrm{m}^{3}$ of treated water, respectively.

Drioli et al. [185] integrated MF-NF-RO system with MDC unit for the treatment of rejected brines. Comprehensive process modelling and energy analysis revealed that thermal energy, if available, would increase freshwater recovery by up to $92.8 \%$ without a significant increase in cost of treatment. An Aspen flow sheet simulation shows that integration of crystallization unit with MD module has little effect on total energy consumption of MDC system, and $97.5 \%$ of the energy was consumed by the heater required to heat MD feed water [186]. Furthermore, if the heat recovery unit is utilized, GOR can be increased to 0.58-0.79. To reduce the recirculation heat losses, a submerged MDC reactor which included hydrophobic hollow fibers immersed in a crystallizer unit and vacuum inside the fibers was suggested [187]. The authors evaluated the effect of transverse vibrations and feed aeration on vapor mass transfer, membrane fouling and crystallization process. Even with feed water having conductivity as high as $61.2 \mathrm{mS} / \mathrm{cm}$, both techniques reduced concentration and temperature polarization. Sustainable MDC performance was achieved for more than $700 \mathrm{~h}$ in optimal conditions. Recently, Choi et al. [188] suggested a novel approach by introducing a fractionalsubmerged MD crystallizer (F-SMDC) system. The reactor's space was separated by creating different conditions at the reactor's top and bottom parts. As such, the upper part of the reactor served as MD due to higher temperature and lower concentration of the feed, and lower part of the reactor served as crystallizer due to higher feed concentration and lower feed temperature (Fig. 7). The advantages of such reactor included high liquid recovery, reduced scaling and production of homogeneous $\mathrm{Na}_{2} \mathrm{SO}_{4}$ crystals.

A hybrid system that integrated MD and cooling crystallization has been suggested by Luo et al. [189] for water recovery and extraction of $\mathrm{NaCl}$ crystals. The authors fabricated hollowfiber PVDF fibers to utilize for water recovery in MD and as heat exchangers in crystallization. A Taguchi's method had been further applied to optimize system's performance with respect to feed temperature and quantities of distillated and washed waters. As a result, a vapor flux as high as $8 \mathrm{~kg} / \mathrm{m}^{2} \mathrm{~h}$ and $64 \mathrm{~g} / \mathrm{kg}$ of feed were achieved during 15 -cycle experiments. 


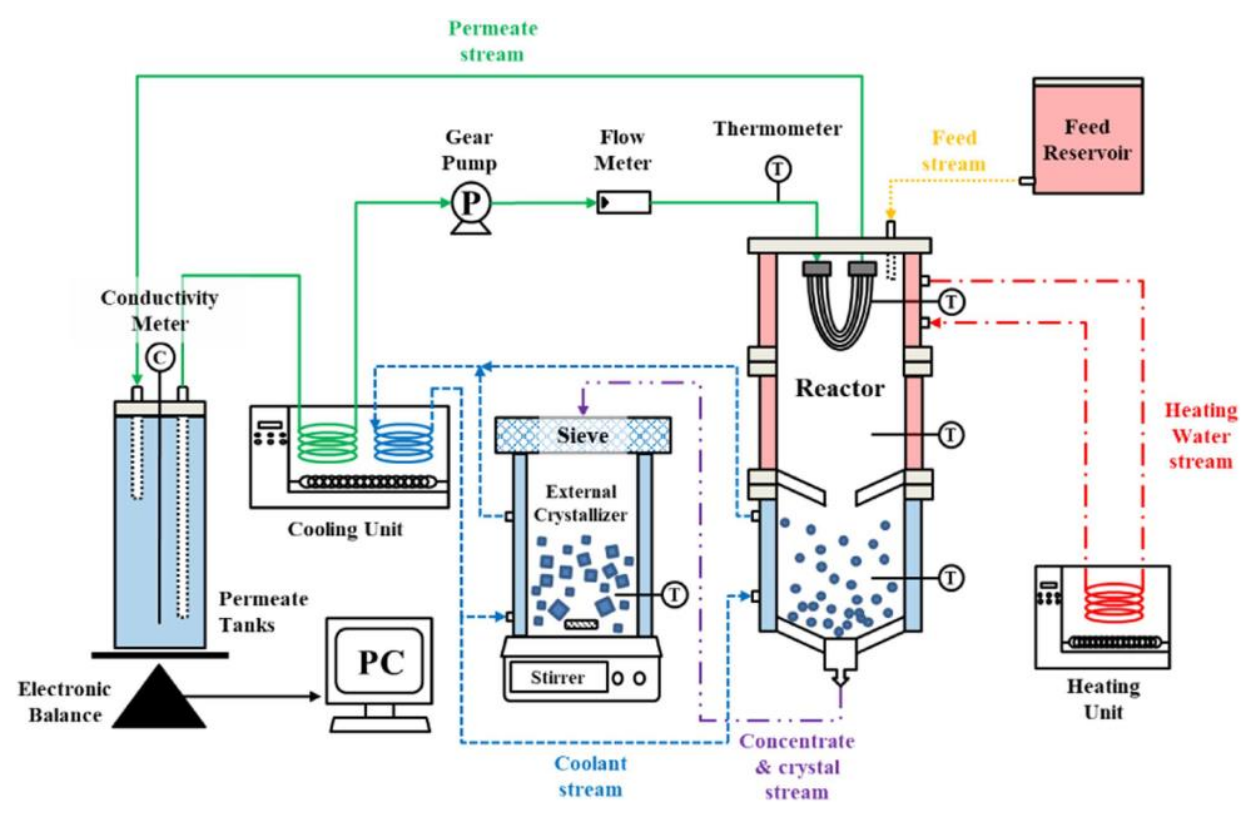

Fig. 7 Schematic of the MDC system. Crystallization occurs in both submerged MD module and external crystallizer [188].

\section{HYBRIDIZATION OF MD WITH EMERGING PROCESSES}

\subsection{AD-MD hybrid}

$\mathrm{AD}$ is another emerging simple and scalable technology, which has great potential for commercialization at large scale, especially for niche applications. A Detailed description of the $\mathrm{AD}$ concept and its main advantages can be found elsewhere $[13,190])$. A short overview of this process is discussed in this review with a focus set on its potential hybridization with MD.

In recent years, several authors $[13,191,192]$ have reported a low-energy adsorptiondesorption cycle for desalination applications using silica gel as low-cost and durable adsorbent. The pore diameters and the total pore surface area of this adsorbent range from 10 $\mathrm{nm}$ to $40 \mathrm{~nm}$ and from $600 \mathrm{~m}^{2} / \mathrm{g}$ to $800 \mathrm{~m}^{2} / \mathrm{g}$, respectively. The AD cycle uses a relatively low temperature heat source in the sorption cycle for simultaneous cooling (in the range of $7-20^{\circ} \mathrm{C}$ ) and distilled water production (salinity $<10 \mathrm{ppm}$ ). The mesoporous adsorbent packed in layers inside containers sucks naturally water vapor produced inside the evaporator at very low temperature and pressure. Raw seawater feeds the evaporator after deaeration (used as pretreatment step to remove non condensable gases) at its ambient temperature, which makes it an attractive low-energy process compared to other thermally-driven processes where typically large amount of feed water is heated [10]. The desorption cycle (the release of water 
vapor from the adsorbent material) is assured by recirculating hot water (in the range of 60-70 ${ }^{\circ} \mathrm{C}$ ) through the layers of the adsorbent in a closed-loop connected with the heat exchanger to get advantage of the heat recovery. All the AD components operate under vacuum. The process comprises two half cycles operating with intervals varying from 200 seconds to 700 seconds and a switching interval varying from 20 seconds to 40 seconds to handle either preheating or cooling of the exchangers [193]. Finally, the released water vapor is condensed outside the unit and collected as product water. Under these operating conditions, fouling or scaling are unlikely to occur.

In addition to the combination of hot water used for AD desorption with MD feed, there are two other possible integrations of MD with $\mathrm{AD}$ in hybrid systems. The first one consists of using the produced chilled water generated from the AD evaporator in a closed-loop as a coolant for DCMD or AGMD. The second attractive combination, as suggested by Kim et al. [194], is to use the low vacuum pressure naturally created by adsorbents during the adsorption cycle to drive a VMD system without the need for a vacuum pump. The synergetic integration of these processes is proven where the useful effect of adsorption cycle is coupled to enhance the operation of the VMD system. This is achieved by using the low vacuum environment created between the evaporator and adsorbents of the AD cycle to assure a high transmembrane pressure gradient (vacuum applied at the coolant side of VMD). In a theoretical investigation with experimental validation, Kim et al. [194] studied the water recovery ratio and total water production of a solar-driven multi stage AD-VMD hybrid unit. The authors observed an increase of $23 \%$ water recovery ratio and $21 \%$ of water production as compared to a stand alone VMD unit by using an external vacuum pump to drive the process, making the studied hybrid system a very attractive and energy efficient process for desalination application.

It was found that the vapor flux of the hybrid system decreased from $53 \mathrm{~kg} / \mathrm{m}^{2} \mathrm{~h}$ to $5 \mathrm{~kg} / \mathrm{m}^{2} \mathrm{~h}$ compared to stand alone VMD process of which flux decreased from $29 \mathrm{~kg} / \mathrm{m}^{2} \mathrm{~h}$ to $6 \mathrm{~kg} / \mathrm{m}^{2} \mathrm{~h}$, which was mainly attributed to an asymptotic decline of the driving force along channels of the different stages. On the other hand, brine concentration increased from $4.5 \mathrm{wt} \%$ to $5.7 \mathrm{wt} \%$ for standalone VMD and from $4.5 \mathrm{wt} \%$ to $6.1 \mathrm{wt} \%$ when the process was integrated with AD. However, the authors did not investigate the effect of integrating the MD evaporation with the $\mathrm{AD}$ adsorbents load on the overall system. This can be done through life cycle and cost analysis.

Schematic of the AD-VMD process diagram is presented in Fig. 8 [194]. In the adsorptiondesorption cycle, a pair of adsorber beds containing a highly porous hydrophilic adsorbent is connected to each stage of the permeate side of the VMD modules to use the applied vacuum 
and assure the high transmembrane water vapor pressure gradient. Therefore, vacuum provided by the adsorbents is employed to create a sufficient partial vapor pressure difference that could drive the VMD unit. As explained above, after adsorbents get saturated with water vapor, the desorption cycle is applied to release the vapor collected from both VMD modules AD evaporator and flows through a pipe connected to an external condenser where it gets condensed and collected as final distilled water product.

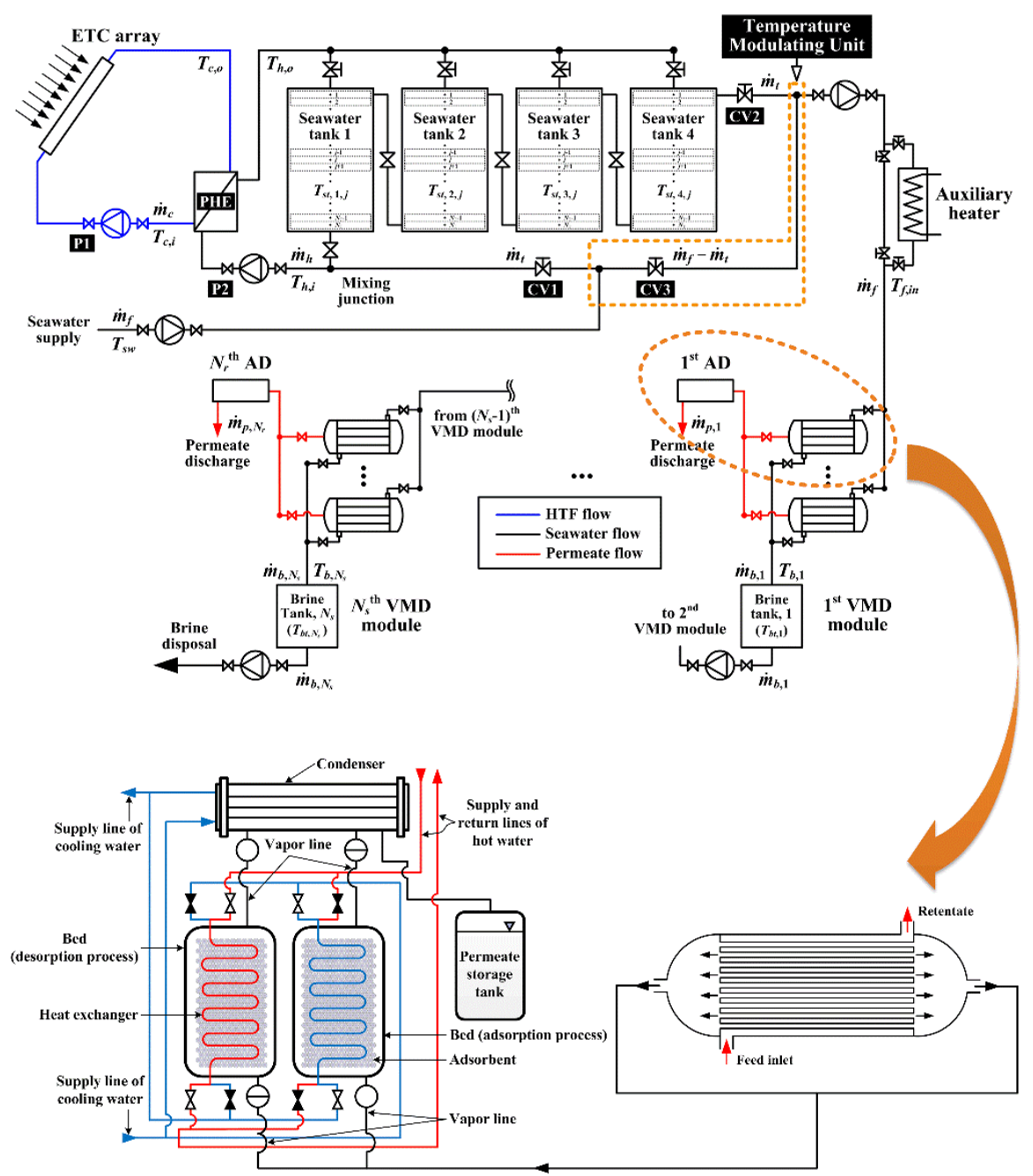

Fig. 8 Schematic of solar-assisted multi-stage AD-VMD hybrid desalination system [194].

\subsection{FO-MD hybrid}

FO is an osmotically driven separation process, which uses a semi-permeable membrane. It is considered as a low energy desalting process [195], since it utilizes a high concentration stream namely a draw solution, DS and a low concentration feed solution, FS to create an osmotic pressure gradient to drive water flux. One of the main FO drawbacks is that it requires an additional recovery process, such as distillation [196], MD [197], NF [198] or RO [199] to 
regenerate the concentrated DS and produce fresh water (Fig. 9). Compared to ionic organics, inorganics are more appropriate for FO as an effective draw solute due to their higher osmotic pressure, higher diffusivity and lower viscosity [200]. Therefore, there is great potential to hybridize MD with FO, especially to regenerate the FO DS. As discussed earlier, MD produces high quality water with almost complete salt rejection and is not affected by high salinity feeds encountered in brines, produced water, and hypersaline waters [34].

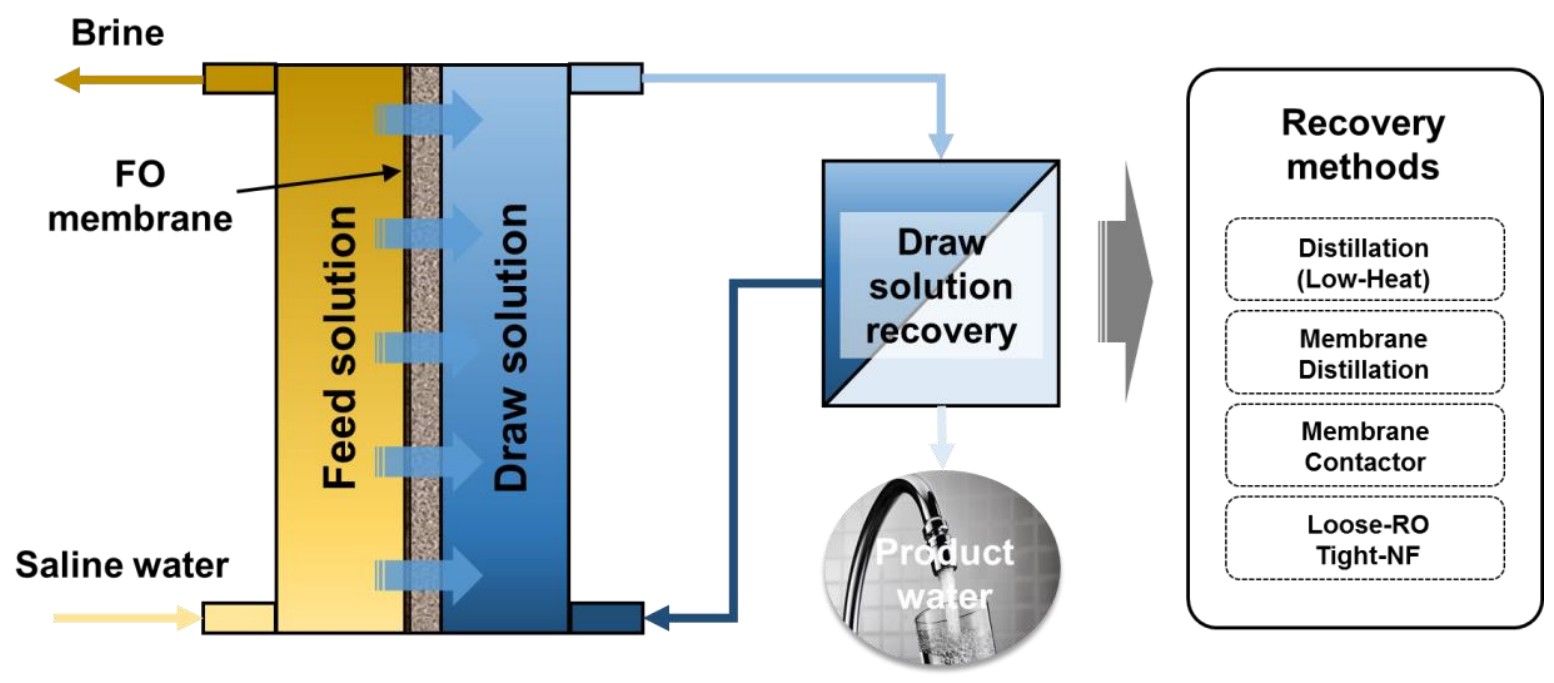

Fig. 9 Schematic diagram of a FO process combined with a DS recovery process for water and wastewater treatments. For the DS recovery, various desalting processes such as distillation, MD, MC, NF and RO can be used depending on DS type.

\subsubsection{Development of DS for FO-MD hybrid system}

In FO process, DS should have high osmotic pressure, low viscosity, high water solubility, high diffusivity, and a small molecular weight [201, 202]. Besides, MD can achieve total inorganics rejection. Based on these criteria, inorganic salts seem to be the most appropriate DS [200]. As a result, $\mathrm{NaCl}$ has often been used for FO-MD hybrid systems [126, 203, 204]. Nevertheless, several researchers conducted additional investigations for inorganic DS to improve the performance of either FO treatment or MD recovery (see Table 1). $\mathrm{NH}_{4} \mathrm{HCO}_{3}$ was suggested as a novel DS in 1960 [205] due to its easy separation into $\mathrm{CO}_{2}$ and $\mathrm{NH}_{3}$ gases at low temperature and its high osmotic pressure, while McGinnis and Elimelech [196] investigated, in terms of energy requirement, various $\mathrm{NH}_{4} \mathrm{HCO}_{3}$ recovery methods including MSF, MED and RO. The authors report that low temperature distillation is the most economic option $\left(0.84 \mathrm{kWh} / \mathrm{m}^{3}\right)$ compared to other desalting processes (i.e., $5.66 \mathrm{kWh} / \mathrm{m}^{3}, 3.21 \mathrm{kWh} / \mathrm{m}^{3}$, $3.0 \mathrm{kWh} / \mathrm{m}^{3}$ for MSF, MED and RO, respectively). 
Table 1 - Summary of draw solutes developed for both FO and MD

\begin{tabular}{|c|c|c|c|c|}
\hline DS type & FO performance & MD performance & Remarks & Ref \\
\hline $\begin{array}{l}\text { Poly(amido- } \\
\text { amine)- } \\
\text { COONa } \\
\text { (PAMAM- } \\
\text { COONa) }\end{array}$ & $\begin{array}{l}\text { - Water flux: } 9 \text { LMH } \\
\text { - DS: } 33.3 \text { wt \% PAMAM- } \\
\text { COONa } \\
\text { - FS: seawater } \\
\text { - AL-FS mode } \\
\text { - HTI TFC FO membrane. }\end{array}$ & $\begin{array}{l}\text { - Water flux: } 3 \mathrm{LMH} \\
\text { - Rejection: } 100 \% \\
\text { - Temperatures of feed } \\
\text { and permeate: } 50{ }^{\circ} \mathrm{C} \\
\text { and } 10^{\circ} \mathrm{C} \\
\text { - DCMD } \\
\text { - PVDF hollow fiber } \\
\text { membrane }\end{array}$ & $\begin{array}{l}\text { - PAMAM-COONa is } \\
\text { suitable for FO owing to } \\
\text { low viscosity, high } \\
\text { osmotic pressure, and } \\
\text { large molecular size. } \\
\text { - Diluted PAMAM- } \\
\text { COONa solution was } \\
\text { readily recovered by } \\
\text { MD. }\end{array}$ & [206] \\
\hline $\begin{array}{l}\text { Decasodium } \\
\text { phytate }\end{array}$ & $\begin{array}{l}\text { - Water flux: } 20 \text { LMH } \\
\text { - Negligible reverse solute } \\
\text { diffusion } \\
\text { - DS: } 1 \text { M DS Na10- } \\
\text { phytate } \\
\text { - FS: DI water } \\
\text { - AL-FS mode } \\
\text { - TFC-PES FO membrane }\end{array}$ & $\begin{array}{l}\text { - Water flux: } 10 \mathrm{LMH} \\
\text { - Rejection: } 100 \% \\
\text { - Temperatures of feed } \\
\text { and permeate: } 50{ }^{\circ} \mathrm{C} \\
\text { and } 20^{\circ} \mathrm{C} \\
\text { - DCMD } \\
\text { - PVDF hollow fiber } \\
\text { membrane }\end{array}$ & $\begin{array}{l}\text {-A multi-charged draw } \\
\text { solute of decasodium } \\
\text { phytate was synthesized } \\
\text { for removing organic } \\
\text { arsenicals. } \\
\text { - At increased DS } \\
\text { temperature, decasodium } \\
\text { phytate enhanced water } \\
\text { flux by more than } 30 \% \text {. } \\
\text { - Organic arsenicals and } \\
\text { DS were perfectly } \\
\text { rejected. }\end{array}$ & [207] \\
\hline $\begin{array}{l}\text { Hydroacid } \\
\text { complex } \\
\left(\mathrm{Na}_{5} \mathrm{Fe}-\mathrm{CA}\right)\end{array}$ & $\begin{array}{l}\text { - Water flux: } 6 \mathrm{LMH} \\
\text { - FS: } 0.6 \mathrm{M} \mathrm{NaCl} \\
\text { - DS: } 60{ }^{\circ} \mathrm{C} 1.5 \mathrm{M} \mathrm{Na} \mathrm{Fe}_{5} \\
\text { CA } \\
\text { - AL-FS mode } \\
\text { - TFC FO membrane }\end{array}$ & $\begin{array}{l}- \text { Water flux: } 30 \mathrm{LMH} \\
\text { - Rejection: } 99.99 \% \\
\text { - FS: } 1.5 \mathrm{M} \text { DS } \\
\text { - Feed temperature: } 60 \\
{ }^{\circ} \mathrm{C} \\
\text { - DCMD } \\
\text { - } 0.2 \mu \mathrm{m} \text { PVDF hollow } \\
\text { fiber membranes }\end{array}$ & $\begin{array}{l}\text { - The hydroacid complex } \\
\text { has low viscosity, high } \\
\text { solubility, good thermal } \\
\text { stability and low RSF. }\end{array}$ & [208] \\
\hline $\begin{array}{l}\text { Hydrolyzed } \\
\text { poly(isobutyle } \\
\text { ne-alt-maleic } \\
\text { acid) (PIAM- } \\
\text { Na) }\end{array}$ & $\begin{array}{l}\text { - Water flux: } 34 \mathrm{LMH} \\
\text { - RSF: } 0.196 \mathrm{gMH} \\
\text { - DS: } 60^{\circ} \mathrm{C} 0.375 \mathrm{~g} / \mathrm{mL} \\
\text { - FS: DI water } \\
\text { - AL-FS mode } \\
\text { - HTI CTA FO membrane }\end{array}$ & $\begin{array}{l}\text { - Water flux: } 35 \mathrm{LMH} \\
\text { - FS: } 0.375 \mathrm{~g} / \mathrm{mL} \mathrm{DS} \\
\text { - Temperatures of feed } \\
\text { and permeate: } 60^{\circ} \mathrm{C} \\
\text { and } 20^{\circ} \mathrm{C} \\
-\mathrm{DCMD} \\
\text { - } 0.2 \mu \mathrm{m} \text { PVDF flat } \\
\text { sheet membrane }\end{array}$ & $\begin{array}{l}\text { - PIAM-Na has non- } \\
\text { toxicity, low viscosity } \\
\text { and high osmotic } \\
\text { pressure. } \\
\text { - PIAM-Na has two } \\
\text { glass-liquid transition } \\
\text { temperature values } \\
\text { higher than operation } \\
\text { temperature. }\end{array}$ & [209] \\
\hline $\begin{array}{l}\text { Poly (aspartic } \\
\text { acid sodium } \\
\text { salt) (PAspNa) }\end{array}$ & $\begin{array}{l}\text { - Water flux: } 8 \text { LMH } \\
\text { - RSF: } 2.4 \mathrm{gMH} \\
\text { - DS: } 0.3 \mathrm{~g} / \mathrm{mL} \text { PAspNa } \\
\text { - FS: DI water } \\
\text { - AL-FS mode } \\
\text { - HTI CTA FO membrane }\end{array}$ & $\begin{array}{l}\text { - Water flux: } 15 \mathrm{LMH} \\
\text { - Rejection: } 99.9 \% \\
\text { - FS: } 0.3 \mathrm{~g} / \mathrm{ml} \\
\text { - Temperatures of feed } \\
\text { and permeate: } 60^{\circ} \mathrm{C} \\
\text { and } 20^{\circ} \mathrm{C} \\
\text { - DCMD } \\
\text { - } 0.2 \mu \mathrm{m} \text { PTFE flat } \\
\text { sheet membrane } \\
\end{array}$ & $\begin{array}{l}\text { - PAspNa produces high } \\
\text { osmotic pressure. } \\
\text { - The reversely diffused } \\
\text { PAspNa could inhibit the } \\
\text { scaling formation }\end{array}$ & [210] \\
\hline $\mathrm{NH}_{4} \mathrm{HCO}_{3}$ & No FO evaluation & $\begin{array}{l}\text { - Rejection: higher than } \\
94 \% \mathrm{NH}_{3} \text { and } \mathrm{CO}_{2} \\
\cdot \text { Feed temperature: } \\
40^{\circ} \mathrm{C} \sim 60^{\circ} \mathrm{C} \\
\cdot \mathrm{VMD} \\
\cdot 0.3 \mu \mathrm{m} \text { PP flat sheet } \\
\text { membrane }\end{array}$ & $\begin{array}{l}-\mathrm{NH}_{3} \text { and } \mathrm{CO}_{2} \text { gases } \\
\text { were separated from } \\
\mathrm{NH}_{4} \mathrm{HCO}_{3} \text { solution. } \\
\text { - At initial FS } \\
\text { temperature of } 40^{\circ} \mathrm{C} \text {, gas } \\
\text { removal efficiency was } \\
\text { low compared to that at } \\
50^{\circ} \mathrm{C} \text { and } 60^{\circ} \mathrm{C} \text {. }\end{array}$ & [211] \\
\hline
\end{tabular}




\begin{tabular}{|c|c|c|c|c|}
\hline $\begin{array}{c}\mathrm{Al}_{2}\left(\mathrm{SO}_{4}\right)_{3} \\
\text { blended } \\
\mathrm{MgCl}_{2} \\
\text { solution }\end{array}$ & $\begin{array}{l}\text { - Water flux: } 4.8 \mathrm{LMH} \text {, } \\
\text { 4.09 LMH and } 1.74 \mathrm{LMH} \\
\text { - RSF: } 0.53 \mathrm{gMH} \\
\text { - FS: DI water, } 5 \mathrm{~g} / \mathrm{L} \text { and } \\
35 \mathrm{~g} / \mathrm{L} \\
\text { - DS: } 0.5 \mathrm{M} \mathrm{MgCl}_{2} \\
\text { blended with } 0.05 \mathrm{M} \\
\mathrm{Al}_{2}\left(\mathrm{SO}_{4}\right)_{3} \\
\text { - AL-FS mode } \\
\text { - HTI CTA FO membrane }\end{array}$ & $\begin{array}{l}\text { - Water flux: } 5.41 \\
\text { LMH } \\
\text { - Rejection: } 99.9 \% \\
\text { - Temperatures of feed } \\
\text { and permeate: } 55^{\circ} \mathrm{C} \\
\text { and } 25^{\circ} \mathrm{C} \\
\text { - DCMD } \\
\text { - } 0.45 \mu \mathrm{m} \text { PTFE flat } \\
\text { sheet membrane }\end{array}$ & $\begin{array}{l}\text { - } \mathrm{Al}_{2}\left(\mathrm{SO}_{4}\right)_{3} \text { blended } \\
\mathrm{MgCl}_{2} \mathrm{DS} \text { was proposed. } \\
\text { - The formation of } \\
\text { aluminum hydroxide in } \\
\text { DS reduced RSF by } \\
\text { restricting pores. }\end{array}$ & {$[212]$} \\
\hline $\begin{array}{l}\text { Triton-X } 114 \\
\text { surfactant } \\
\text { blended } \\
\text { poly(propylen } \\
\text { e glycol) } \\
\text { (PPG) solution }\end{array}$ & $\begin{array}{l}\text { - Water flux: } 10 \mathrm{LMH} \\
\text { - RSF: } 0.18 \mathrm{gMH} \\
\text { - SRSF: } 0.018 \mathrm{~g} / \mathrm{L} \\
\text { - DS: } 40 \% \text { PPG-725 } \\
\text { blended with } 0.8 \mathrm{mM} \\
\text { Triton X-114 } \\
\text { - AL-FS mode } \\
\text { - HTI TFC FO membrane }\end{array}$ & $\begin{array}{l}\text { - Rejection: } 97 \% \\
\text { - FS: } 40 \% \text { PPG-725 / } \\
0.8 \mathrm{mM} \text { Triton X-114 } \\
\text { - } 40^{\circ} \mathrm{C} \text { temperature } \\
\text { difference } \\
\text { - DCMD } \\
\text { - } 0.4 \mu \mathrm{m} \text { PTFE flat } \\
\text { sheet membrane }\end{array}$ & $\begin{array}{l}\text { - PPG incorporated with } \\
\text { triton X-114 was } \\
\text { proposed owing to high } \\
\text { osmolality. } \\
\text { - PPG-725 was found to } \\
\text { be less toxic. }\end{array}$ & {$[213]$} \\
\hline $\mathrm{Na}_{3} \mathrm{PO}_{4}$ & $\begin{array}{l}\text { - Water flux: } 12.5 \mathrm{LMH} \\
\text { - RSF: } 0.84 \mathrm{gMH} \\
\text { - SRSF: } 0.37 \mathrm{~g} / \mathrm{L} \\
\text { - DS: pH } 90.1 \mathrm{M} \mathrm{Na} \mathrm{PO}_{4} \\
\text { - FS: DI water } \\
\text { - AL-FS mode } \\
\text { - HTI TFC FO membrane }\end{array}$ & $\begin{array}{l}\text { - Water flux: } 10.28 \\
\text { LMH } \\
\text { - Rejection: } 100 \% \\
\text { - FS: Diluted } \mathrm{Na}_{3} \mathrm{PO}_{4} \\
\text { solution } \\
\text { - Temperatures of feed } \\
\text { and permeate: } 50^{\circ} \mathrm{C} \\
\text { and } 25^{\circ} \mathrm{C} \\
\text { - DCMD } \\
\text { - } 0.45 \mu \mathrm{m} \text { PTFE flat } \\
\text { sheet membrane }\end{array}$ & $\begin{array}{l}\text { - Highly charged } \\
\text { phosphate DS could } \\
\text { concentrate the sludge } 6 \\
\text { times. }\end{array}$ & {$[214]$} \\
\hline $\begin{array}{l}\text { Chlorhexidine } \\
\text { gluconate } \\
\text { based } \\
\text { mouthwash } \\
\text { (CMW) }\end{array}$ & $\begin{array}{l}\text { - Water flux: } 14.48 \mathrm{LMH} \\
\text { - RSF: } 1 \mathrm{gMH} \\
\text { - SRSF: } 0.07 \mathrm{~g} / \mathrm{L} \\
\text { - DS: } 100 \% \mathrm{CMW} \\
\text { - FS: DI water } \\
\text { - HTI TFC FO membrane }\end{array}$ & $\begin{array}{l}\text { - Water flux: } 6.1 \mathrm{LMH} \\
\text { - Rejection: } 95.98 \% \\
\text { - } 55^{\circ} \mathrm{C} \text { temperature } \\
\text { difference } \\
\text { - DCMD } \\
\text { - } 0.45 \mu \mathrm{m} \text { PTFE flat } \\
\text { sheet membrane }\end{array}$ & $\begin{array}{l}\text { - } \mathrm{CMW} \text { is re-usable as } \\
\text { well as much less toxic } \\
\text { and it has high } \\
\text { osmolality. }\end{array}$ & {$[215]$} \\
\hline $\begin{array}{l}\text { Multi-charged } \\
\text { oxalic acid }\end{array}$ & $\begin{array}{l}\text { - Water flux: } 27.5 \mathrm{LMH} \\
\text { - Negligible RSF } \\
\text { - DS: } 2 \mathrm{M} \mathrm{NH}_{4}-\mathrm{Cr}-\mathrm{OA} \\
\text { - FS: DI water } \\
\text { - AL-FS mode } \\
\text { - TFC PES FO membrane }\end{array}$ & $\begin{array}{l}\text { - Water flux: } 13 \mathrm{LMH} \\
\text { - Rejection: } 100 \% \\
\text { - FS: } 2 \mathrm{M} \mathrm{NH} \text {-Cr-OA } \\
\text { - Temperatures of feed } \\
\text { and permeate: } 50^{\circ} \mathrm{C} \\
\text { and } 20^{\circ} \mathrm{C} \\
\text { - DCMD } \\
\text { - PVDF hollow fiber } \\
\text { membrane }\end{array}$ & $\begin{array}{l}\text { - Oil-water separation } \\
\text { was successful with FO } \\
\text { and MD could recover } \\
\text { oxalic acid complexes } \\
\text { DS. }\end{array}$ & {$[216]$} \\
\hline EDTA-2Na & No FO evaluation & $\begin{array}{l}\text { - Water flux: } 9 \text { LMH } \\
\text { - Rejection: } 99.99 \% \\
\text { - FS: } 0.1 \text { M EDTA-2Na } \\
\text { - } 50^{\circ} \mathrm{C} \text { temperature } \\
\text { difference } \\
\text { - DCMD } \\
\text { - } 0.45 \mu \mathrm{m} \text { PTFE flat } \\
\text { sheet membrane }\end{array}$ & $\begin{array}{l}-0.45 \mu \mathrm{m} \text { PTFE } \\
\text { membrane was the best } \\
\text { for DS recovery. } \\
\text { - MD performance was } \\
\text { severely influenced by } \\
\text { trans-membrane } \\
\text { temperature. }\end{array}$ & {$[217]$} \\
\hline $\begin{array}{l}\text { Poly(acrylic } \\
\text { acid) sodium } \\
\text { (PAA-Na) }\end{array}$ & $\begin{array}{l}\text { - Water flux: } 40 \mathrm{LMH} \\
\text { - RSF: } 0.14 \mathrm{gMH} \\
\text { - DS: } 80^{\circ} \mathrm{C} 0.6 \mathrm{~g} / \mathrm{mL} \\
\text { PAA-Na } \\
\text { - FS: DI water } \\
\text { - AL-DS mode }\end{array}$ & $\begin{array}{l}\text { - Water flux: } 25 \text { LMH } \\
\text { - Rejection: } 100 \% \\
\text { - DCMD } \\
\text { - PVDF hollow fiber } \\
\text { membrane }\end{array}$ & $\begin{array}{l}\cdot \text { High water flux, low } \\
\text { RSF, and ease of } \\
\text { recovery was observed. } \\
\cdot 0.48 \mathrm{~g} / \mathrm{mL} \text { PAA-Na and } \\
66^{\circ} \mathrm{C} \text { was the optimum } \\
\text { condition for wastewater } \\
\text { dehydration. }\end{array}$ & {$[218]$} \\
\hline
\end{tabular}




\begin{tabular}{|c|c|c|c|c|}
\hline & $\begin{array}{l}\text { - CA hollow fiber FO } \\
\text { membrane }\end{array}$ & & & \\
\hline $\begin{array}{l}\text { Poly(sodiumst } \\
\text { yrene-4- } \\
\text { sulfonate-co- } \\
n- \\
\text { isopropylacryl } \\
\text { amide) (PSSS- } \\
\text { PNIPAM) }\end{array}$ & $\begin{array}{l}\text { - Water flux: } 4 \text { LMH } \\
\text { - FS: Simulated seawater } \\
\text { - DS: PSSS-PNIPAM } \\
\text { - HTI TFC FO membrane }\end{array}$ & $\begin{array}{l}\text { - Water flux: } 2.7 \mathrm{LMH} \\
\text { - Temperatures of feed } \\
\text { and permeate: } 50^{\circ} \mathrm{C} \\
\text { and } 10^{\circ} \mathrm{C} \\
\text { - DCMD } \\
\text { - PVDF hollow fiber } \\
\text { membrane }\end{array}$ & $\begin{array}{l}\text { - The DS osmotic } \\
\text { pressure was thermally } \\
\text { controlled. } \\
\text { - The thermoresponsive } \\
\text { behavior facilitated DS } \\
\text { regeneration via MD. }\end{array}$ & [219] \\
\hline
\end{tabular}

For more effective DS recovery, Shim et al. [211] evaluated VMD to separate $\mathrm{NH}_{4} \mathrm{HCO}_{3}$ DS into $\mathrm{NH}_{3}$ and $\mathrm{CO}_{2}$ gases and achieved removal efficiencies higher than $94 \%$. Nevertheless, produced water may not meet drinking standard due to the presence of toxic $\mathrm{NH}_{3}$. Nguyen et al. [214] evaluated $\mathrm{Na}_{3} \mathrm{PO}_{4}$ as DS for its high charge property, to lower reverse salt flux (RSF) and increase water flux. Nguyen et al. [212] also introduced an $\mathrm{MgCl}_{2}$ draw solution with small concentrations of $\mathrm{Al}_{2}\left(\mathrm{SO}_{4}\right)_{3}$ for reduction of $\mathrm{RSF}$, possibly via membrane pores constriction caused by aluminum hydroxide flocculation in the mixed DS. Besides, MD performed a complete regeneration of the diluted DS owing to utilization of inorganic salts.

A variety of organic DS has also been investigated since their high molecular weights can lower RSF in FO. However, the organic DS can exhibit lower water flux than inorganic DS due to low osmotic pressure and low diffusivity. Therefore, many researchers focused on modified structures such as highly charged or functionalized ionic organic compounds to increase osmotic pressure of the organic DS. Wang et al. [208] introduced hydroacid complex such as $\mathrm{Na} 5\left[\mathrm{Fe}\left(\mathrm{C}_{6} \mathrm{H}_{4} \mathrm{O}_{7}\right)_{2}\right]$ for its low RSF, low viscosity, high solubility, and good thermal stability. Nguyen et al. [212] examined different hydrophobic membranes for the efficient recovery of EDTA-2Na DS and found out that PTFE membrane is the most appropriate. Ge et al. [216] evaluated multi-charged oxalic acid regenerated by MD for oil-water separation by FO. They have proved that MD can be suitable for recovering organic DS as it offers a rejection higher than $99.9 \%$. Ray et al. [215] introduced chlorhexidine gluconate based mouthwash (CMW) due to its high osmotic pressure, low toxicity and its potential reuse. However, its rejection by MD was slightly lower than values reported by other researchers, possibly due to the presence of volatile organics such as methanol.

Polyelectrolyte DS has been considered as a novel DS in FO-MD hybrid system for its high water flux, low RSF and the economic DS recovery. Ge et al. [218] proposed poly(acrylic acid) sodium (PAA-Na) as a DS for its easy separation, high water flux and low RSF. Zhao et al. [206] evaluated poly(amidoamine)-COONa (PAMAM-COONa) since it offers unique advantages including low viscosity, high osmotic pressure and relatively large molecular size. 
Kumar et al. [209] introduced hydrolyzed poly(isobutylene-alt-maleic acid) (PIAM-Na) as a DS owing to its non-toxicity, low viscosity and high osmotic pressure. In addition, it showed two temperature values of glass transition higher than the operating temperature, which enables a stable operation of the hybrid system. Gwak et al. [210] examined poly (aspartic acid sodium salt) (PAspNa) due to its large configuration and high osmolality. Interestingly, the reversely diffused PAspNa to the feed acted as an antiscalant. Ray et al. [213] proposed poly(propylene glycol) (PPG) blended with a surfactant (Triton-X 114) to maximize water flux and prevent DS leakage.

Zhao et al. [219] evaluated poly(sodiumstyrene-4-sulfonate-co-n-isopropylacrylamide) (PSSS-PNIPAM) as a thermo-responsive DS and found out that PSSS-PNIPAM could thermally control its osmotic pressure and the thermo-responsive behavior could be utilized for DS regeneration via MD. Besides, thermo-responsive acidic microgels [220] and thermoresponsive copolymers [221] were also proposed as novel DS for FO even though they used other techniques to regenerate the DS. However, their applications might be limited due to low performance as low permeate rates were reported; 4 LMH [219], 3.1 LMH [220], and 5.45 LMH [221]). Furthermore, these DS may require large energy consumption as they go through repetitive cooling and heating procedures. As a matter of fact, the equivalent work required for heating water by $30^{\circ} \mathrm{C}$ would be approximately $29 \mathrm{kWh} / \mathrm{m}^{3}$ [219].

\subsubsection{Applications of FO-MD hybrid systems}

The FO-MD hybrid system has been considered for various applications including seawater desalination and wastewater treatment (see Table 2 and Table 3). Regarding seawater desalination, many researchers evaluated the FO-MD hybrid system using different DS including inorganics and polyelectrolytes [206, 208, 212, 219, 222]. They confirmed feasibility of this system for seawater desalination since operating the DS at high temperature enhances water flux and achieves high rejection. However, most studies were only conducted for basic performance i.e. water flux, RSF and total rejection. Therefore, long-term operation of FO-MD hybrid need to be carried out to evaluate any potential problems such as membrane fouling. In addition to seawater desalination, Lee et al. [126] evaluated the FO-MD hybrid system to treat $\mathrm{RO}$ brine by comparing with RO and MD. They found out that $\mathrm{CaCO}_{3}$ scaling causes severe flux decline.

Wastewater treatment by FO-MD was the focus of several investigations [126, 154, 223225]. Husnain et al. [223] designed and tested a unique three-channel FO-MD module to treat 
synthetic domestic wastewater. They found out that this system had a synergistic effect on the rejection property, resulting in $99.9 \%$ rejection rates of $\mathrm{NH}_{4}{ }^{+}, \mathrm{COD}$, arsenic and combined solutes. Moreover, the authors could readily control fouling by increasing shear force created by high cross-flow velocity. In MD, any flux recovery was not observed because organic foulants were adsorbed onto the hydrophobic surface, which allowed contaminants to cross the membrane and cause wetting [224]. Li et al. [225] evaluated the FO-MD hybrid process for treating real domestic wastewater. Higher than $90 \%$ rejections of TOC, total nitrogen (TN) and total phosphate (TP) could be achieved by this hybrid system. The fouling layer on the FO membrane was mainly composed of organic substances such as proteins and polysaccharides. Because of its loose structure, the fouling layer could be readily removed by simple washing with tap water. On the other hand, inorganic fouling was mainly formed on the MD membrane, which was not severe as much as membrane fouling in FO.

Other applications of FO-MD hybrid system were investigated. Liu et al. [197] built and examined an hybridized FO-MD system for treatment of actual human urine. The hybrid system showed almost perfect rejection of contaminants. Furthermore, the quality of the FOMD produced water was much higher than the quality of water produced by MD alone. Volpin et al. [226] investigated the strategies to increase the rejection of Urea via applying backpressure and acidizing the FS. Nguyen et al. [214] evaluated sludge dewatering via FO-MD and showed that sludge could be concentrated up to 6 times. Xie et al. [227] also used FO-MD for direct sewer mining (i.e., struvite) as well as wastewater reuse since the hybrid system was able to achieve up to $98 \%$ removal of trace organic contaminants.

Oily wastewater is commonly encountered in oil storage, oil refining, petrochemical industry, oil industry and transportation [228]. To prevent oily wastewater pollution, appropriate wastewater treatment is required. However, such treatment remains very challenging since oily wastewater cannot be readily treated by thermal distillation due to volatile components [229]. Moreover, it can cause severe and irreversible fouling on RO membranes [230]. However, the FO-MD process can be suitable owing to the high reversibility of FO membrane fouling [230, 231] and high rejection in both FO and MD processes [203, 232]. Li et al. [233] evaluated the FO-VMD hybrid system to reclaim water from shale gas drilling flow-back fluid (SGDF) and reached almost 90\% recovery rate. Zhang et al. [203] treated highly concentrated oil solution using the FO-MD hybrid system achieving at least $90 \%$ water recovery. Interestingly, FO could reject $99.9 \%$ of oil and MD could achieve $99.99 \%$ salt rejection, leading the successful treatment of oily wastewater. Treatment of high-salinity 
industrial wastewaters including oil-field produced water was also examined by Kim et al. [234]. The authors claim that the large system was difficult due to the many unknown factors for scale-up. They also stressed out that even though less electric energy is required compared to $\mathrm{RO}\left(0.25 \mathrm{kWh} / \mathrm{m}^{3}\right.$ and $3-5 \mathrm{kWh} / \mathrm{m}^{3}$ for $\mathrm{MD}$ and $\mathrm{RO}$, respectively), low-grade waste heat should be employed for feasibility. Lu et al. [235] proposed an UF, FO and MD integrated system to treat oily water. In this system, oily wastewater at $50^{\circ} \mathrm{C}$ was employed as DS after treatment by UF and its quality met the injection water standard for oil production after utilization by integrated UF-FO-MD system. Hence, this system could achieve three goals, namely; high quality product water, regeneration of injection water and low energy cost.

The FO-MD hybrid system was further used for treatment of wastewater from various sources (e.g., acid dye, dairy wastewater (DWW), leachate, flue gas desulfurization (FGD) wastewater). Ge et al. [218] treated wastewater containing an acid dye using a polyelectrolytepromoted FO-MD hybrid system. Song et al. [236] utilized the FO-MD hybrid system to reclaim actual DWW for urban water recycling. Membrane fouling was significantly influenced by DWW properties, but water flux could be recovered by $90 \%$ after membrane cleaning. Zhou et al. [237] used the FO-MD hybrid system to treat high salinity landfill leachate. The performance of the system in terms of contaminants rejection in high salinity wastewater was better than individual FO or MD. Lee et al. [204] treated FGD wastewater having severe fouling potential via FO-MD hybrid system. Serious fouling, including gypsum, was formed on both FO and MD membranes. Hence, appropriate antiscalant need to be proposed for scaling inhibition in both processes. Furthermore, the concentration of protein solutions by the FOMD hybrid system was studied by Wang et al. [238]. They concentrated a bovine serum albumin (BSA) solution through a stable and continuous operation of the FO-MD hybrid system while maintaining the dehydration rate (i.e., the permeation rate) in FO same to the water vapor production rate in MD. An et al. [239] also demonstrated that the FO-MD hybrid system can successfully concentrate apple juice.

Most research emphasize that FO and MD membranes act as a double barrier for complete rejection of contaminants, organics and inorganics from the impaired-quality water to ultimately guarantee a high-quality product water [240]. Particularly, FO can reject contaminants untreated by MD while MD can completely reject non-volatile compounds, achieving synergy in FO-MD hybrid system. However, some contaminants in DS can accumulate because FO and MD membranes have different rejections of contaminants [197, 227]. Prevention of contaminant accumulation in the DS is ensured by additional processes 
combined with the FO-MD hybrid such as ultraviolet oxidation or granular activated carbon adsorption [227]. This also implies that the FO-MD hybrid system, owing to its high rejection property for all types of contaminants, is suitable for ultrapure water production needed in the pharmaceutical and semiconductor industries.

FO has been considered a low energy-process because it only requires electrical energy for flow circulation, thereby resulting in low SEC. Kim et al. [241] reported less than $0.1 \mathrm{kWh} / \mathrm{m}^{3}$ at $50 \%$ recovery for treatment of coal seam gas RO brine. Although energy consumption increases to few $\mathrm{kWh} / \mathrm{m}^{3}$ when draw solution recovery is considered [242, 243]. Hence, the total energy efficiency of the FO-MD hybrid strongly depends on MD part performance. Heating up $1 \mathrm{~m}^{3}$ of pure water from room temperature $\left(20^{\circ} \mathrm{C}\right)$ to minimum operation temperature $\left(50^{\circ} \mathrm{C}\right)$, requires approximately $35 \mathrm{kWh} / \mathrm{m}^{3}$, which makes the FO-MD hybrid an energy intensive process [219]. Therefore, finding a suitable low cost heat energy source that can be integrated with the FO-MD hybrid is important for improving its energy-efficiency. For example, wastewater with low-grade waste heat produced from energy industries for oil/gas and energy production can be a good waste heat source.

Table 2 - Summary of potential application (i.e., all types of wastewater) of FO-MD hybrid systems

\begin{tabular}{|c|c|c|c|c|}
\hline Applications & FO performance & MD performance & Remarks & Ref. \\
\hline $\begin{array}{l}\text { Oily } \\
\text { wastewater }\end{array}$ & $\begin{array}{l}\text { - Water flux: } 23 \text { LMH } \\
\text { - Oil rejection: } 99.9 \% \\
\text { - Acetic acid rejection: } \\
82.1 \% \\
\text { - FS: } 100,000 \text { ppm oil } \\
\text { - DS: } 2 \mathrm{M} \mathrm{NaCl} \\
\text { - AL-FS mode } \\
\text { - CTA TFC hollow fiber } \\
\text { membrane }\end{array}$ & $\begin{array}{l}\text { - Water flux: } 5.8 \mathrm{LMH} \\
\text { - Salt rejection: } 99.99 \% \\
\text { - Acetic acid rejection: } \\
47.1 \% \\
\text { - Temperatures of feed } \\
\text { and permeate: } 60^{\circ} \mathrm{C} \text { and } \\
12^{\circ} \mathrm{C} \\
\text { - DCMD } \\
\text { - } 0.2 \mu \mathrm{m} \text { PVDF flat } \\
\text { sheet membrane }\end{array}$ & $\begin{array}{l}\text { - Despite oil fouling, water flux was } \\
\text { stable during } 24 \mathrm{~h} \text {. } \\
\text { - The hybrid FO-MD system } \\
\text { achieved higher than } 90 \% \text { water } \\
\text { recovery and perfectly rejected oil } \\
\text { and salt. } \\
\text { - Acetic acid was permeated and } \\
\text { recovered by FO-MD. }\end{array}$ & [203] \\
\hline $\begin{array}{l}\text { Oily } \\
\text { wastewater }\end{array}$ & $\begin{array}{l}\text { - Water flux: } 6.5 \mathrm{LMH} \\
\text { - FS: } 5 \mathrm{mg} / \mathrm{L} \text { oil } \\
\text { - DS: } 0.25 \mathrm{M} \mathrm{NaCl} \\
\text { - AL-FS mode } \\
\text { - HTI CTA FO } \\
\text { membrane }\end{array}$ & $\begin{array}{l}\text { - Water flux: } 10.5 \mathrm{LMH} \\
\text { - Total rejection: higher } \\
\text { than } 99.5 \% \\
\text { - Feed temperature: } 50 \\
{ }^{\circ} \mathrm{C} \\
\text { - DCMD } \\
\text { - } 0.45 \mu \mathrm{m} \text { PTFE flat } \\
\text { sheet membrane }\end{array}$ & $\begin{array}{l}\text { - For reuse of oily water, a } \\
\text { temperature-salt content } \\
\text { equilibrium curve was proposed. } \\
\text { - The FO-MD hybrid system } \\
\text { incorporated oily water energy } \\
\text { could extract water from sewage } \\
\text { and oily water. }\end{array}$ & {$[235]$} \\
\hline $\begin{array}{l}\text { Oily } \\
\text { wastewater }\end{array}$ & $\begin{array}{l}\text { - Water Flux: } 25 \text { to } 15 \\
\text { LMH } \\
\text { - FS: Pretreated shale } \\
\text { gas drilling flow-back } \\
\text { fluid } \\
\text { - DS: } 3 \mathrm{M} \mathrm{KCl}\end{array}$ & $\begin{array}{l}\text { - Water flux: } 25 \text { to } 10 \\
\text { LMH } \\
\text { - Permeate: } 5 \mu \mathrm{S} / \mathrm{cm} \\
\text { - Feed temperature: } 59 \\
{ }^{\circ} \mathrm{C} \sim 65^{\circ} \mathrm{C} \\
\text { - VMD }\end{array}$ & $\begin{array}{l}\text { - A FO-VMD hybrid system } \\
\text { reclaimed water from SGDF. } \\
\text { - Almost } 90 \% \text { water recovery was } \\
\text { achieved. }\end{array}$ & [233] \\
\hline
\end{tabular}




\begin{tabular}{|c|c|c|c|c|}
\hline & $\begin{array}{l}- \text { AL-FS mode } \\
\text { - HTI CTA FO } \\
\text { membrane }\end{array}$ & $\begin{array}{l}\cdot \mathrm{CF}_{4} \text {-plasma-modified } \\
0.22 \mu \mathrm{m} \text { PVDF flat } \\
\text { sheet membrane }\end{array}$ & $\begin{array}{l}\text { - The hybrid system produced } \\
\text { reclaimed water was as clean as } \\
\text { bottled water. } \\
\text { - FO removed most contaminants } \\
\text { and hence eliminated fouling } \\
\text { potential in MD. }\end{array}$ & \\
\hline $\begin{array}{l}\text { Oily } \\
\text { wastewater }\end{array}$ & $\begin{array}{l}\text { - Water flux: } 0.3 \mathrm{gpm} \\
\text { - FS: Industrial } \\
\text { wastewater from an oil } \\
\text { production field } \\
\text { - DS: } 5 \mathrm{M} \mathrm{NaCl} \\
\text { - Spirial-wound FO } \\
\text { module }\end{array}$ & $\begin{array}{l}\text { - Water flux: } 240 \mathrm{GPD} \\
\text { - Permeate: } 40 \mu \mathrm{S} / \mathrm{cm} \\
\text { and } 79 \text { ppm COD } \\
\text { - DCMD } \\
\text { - Hollow fiber MD } \\
\text { module }\end{array}$ & $\begin{array}{l}\text { - Scale-up was challenging due to } \\
\text { many unknown factors. }\end{array}$ & [234] \\
\hline $\begin{array}{l}\text { Acid dye } \\
\text { wastewater }\end{array}$ & $\begin{array}{l}\text { - Water flux: } 0.18 \mathrm{~L} / \mathrm{m} \\
\text { - FS: Acid orange } 8 \\
\text { - DS: } 66^{\circ} \mathrm{C} 0.48 \mathrm{~g} / \mathrm{mL} \\
\text { PAA-Na } \\
\text { - AL-DS mode } \\
\text { - CA hollow fiber FO } \\
\text { membrane }\end{array}$ & $\begin{array}{l}\text { - Water flux: } 0.18 \mathrm{~L} / \mathrm{m} \\
\text { - Rejection: } 100 \% \\
\text { - FS: } 0.48 \mathrm{~g} / \mathrm{mL} \text { PAA- } \\
\mathrm{Na} \\
\text { - Temperatures of feed } \\
\text { and permeate: } 66^{\circ} \mathrm{C} \text { and } \\
20^{\circ} \mathrm{C} \\
\text { - DCMD } \\
\text { - PVDF hollow fiber } \\
\text { membrane }\end{array}$ & $\begin{array}{l}\text { - Polyelectrolytes have their } \\
\text { advantages such as easy separation, } \\
\text { high water flux, and low RSF. } \\
\text { - Wastewater containing an acid } \\
\text { dye was recycled. } \\
\text { - Optimum condition was } 0.48 \\
\text { g/mL PAA-Na and } 66^{\circ} \mathrm{C} \text {. }\end{array}$ & [218] \\
\hline $\begin{array}{l}\text { Domestic } \\
\text { wastewater } \\
\text { treatment }\end{array}$ & $\begin{array}{l}\text { - Water flux: } 17.6 \mathrm{LMH} \\
\text { - FS: Real domestic } \\
\text { wastewater }\left(20^{\circ} \mathrm{C}\right) \\
\text { - DS: } 35 \mathrm{~g} / \mathrm{L} \mathrm{NaCl}(53 \\
\left.{ }^{\circ} \mathrm{C}\right) \\
\text { - AL-FS mode } \\
\text { - HTI CTA FO } \\
\text { membrane }\end{array}$ & $\begin{array}{l}\text { - Water flux: } 17.6 \mathrm{LMH} \\
\text { - Total rejection: high } \\
\text { than } 90 \% \text { of TOC, TN } \\
\text { and TP } \\
\text { - Temperatures of feed } \\
\text { and permeate: } 53^{\circ} \mathrm{C} \text { and } \\
20^{\circ} \mathrm{C} \\
\text { - DCMD } \\
\text { - } 0.073 \mu \mathrm{m} \text { PVDF } \\
\text { hollow fiber membrane }\end{array}$ & $\begin{array}{l}\text { - Higher molecular weight } \\
\text { contaminants were more readily } \\
\text { rejected. } \\
\text { - The fouling layer was mainly } \\
\text { composed of polysaccharides and } \\
\text { proteins } \\
\text { - Rinsing with tap water was } \\
\text { effective to remove the loose } \\
\text { fouling layer. } \\
\text { - Inorganic fouling was dominant in } \\
\text { MD but not severe as much as in } \\
\text { FO. }\end{array}$ & [225] \\
\hline $\begin{array}{l}\text { Domestic } \\
\text { wastewater } \\
\text { treatment }\end{array}$ & $\begin{array}{l}\text { - Water flux: } 14 \text { LMH } \\
\text { - FS: DI water, } \\
\text { ammonium, and } \\
\text { synthertic wastewater } \\
\text { - DS: } 2 \mathrm{M}, 1 \mathrm{M} \text { and } 0.5 \\
\text { M NaCl } \\
\text { - AL-FS mode } \\
\text { - HTI CTA FO } \\
\text { membrane }\end{array}$ & $\begin{array}{l}\text { - Water flux: } 14 \mathrm{LMH} \\
\text { - Total rejection: } 99.9 \% \\
\text { of } \mathrm{NH} 4+, \mathrm{COD} \text {, arsenic } \\
\text { and combined solutes } \\
\text { - Temperatures of feed } \\
\text { and permeate: } 50^{\circ} \mathrm{C} \text { and } \\
20^{\circ} \mathrm{C} \\
\text { - DCMD } \\
\text { - } 0.22 \mu \mathrm{m} \text { PP flat sheet } \\
\text { membrane }\end{array}$ & $\begin{array}{l}\text { - An integrated FO-MD module } \\
\text { was examined. } \\
\text { - Balancing water flux between FO } \\
\text { and MD was very important for } \\
\text { stable operation. } \\
\text { - The synergistic rejection by FO } \\
\text { and MD membranes enabled high } \\
\text { water quality of effluent. }\end{array}$ & [223] \\
\hline $\begin{array}{l}\text { Domestic } \\
\text { wastewater } \\
\text { treatment }\end{array}$ & $\begin{array}{l}\text { - Water flux: } 3.4 \times 10^{-6} \text { to } \\
1.9 \times 10^{-6} \mathrm{~m} / \mathrm{s} \\
\text { - FS: Synthetic } \\
\text { wastewater } \\
\text { - DS: } 1 \mathrm{M} \mathrm{NaCl} \\
\text { - AL-FS mode } \\
\text { - HTI CTA FO } \\
\text { membrane }\end{array}$ & $\begin{array}{l}\text { - Water flux: } 4 \times 10^{-6} \text { to } \\
1.9 \times 10^{-6} \mathrm{~m} / \mathrm{s} \\
\text { - Temperatures of feed } \\
\text { and permeate: } 50^{\circ} \mathrm{C} \text { and } \\
20^{\circ} \mathrm{C} \\
\text { - DCMD } \\
\text { - } 0.22 \mu \mathrm{m} \text { PP flat sheet } \\
\text { membrane }\end{array}$ & $\begin{array}{l}\text { - Severe flux decline occurred in } \\
\text { FO and MD during wastewater } \\
\text { treatment. } \\
\text { - Hydraulic washing, i.e., increasing } \\
\text { cross-flow, readily removed the } \\
\text { fouling layer. } \\
\text { - For MD, water flux was not } \\
\text { recovered because organic foulants } \\
\text { were attached on the hydrophobic } \\
\text { surface. } \\
\text { - Long-term tests showed that the } \\
\text { hydrophobicity of the MD } \\
\text { membrane was decreasing because } \\
\text { of the accumulation of organic }\end{array}$ & [224] \\
\hline
\end{tabular}




\begin{tabular}{|c|c|c|c|c|}
\hline & & & $\begin{array}{l}\text { foulants on the surface, resulting in } \\
\text { a wetting phenomenon. }\end{array}$ & \\
\hline $\begin{array}{l}\text { Human urine } \\
\text { treatment }\end{array}$ & $\begin{array}{l}\text { - Water flux: } 6 \mathrm{LMH} \\
\text { - FS: Urine solution } \\
\text { - DS: } 2.5 \mathrm{M} \mathrm{NaCl} \\
\text { - AL-FS mode } \\
\text { - HTI CTA FO } \\
\text { membrane }\end{array}$ & $\begin{array}{l}\text { - Water flux: } 7 \mathrm{LMH} \\
\text { - Total rejection: higher } \\
\text { than } 98 \% \text { TOC, TN, and } \\
\mathrm{NH}_{4}^{+}-\mathrm{N} \\
\text { - FS: } 2.5 \mathrm{M} \mathrm{NaCl} \\
\text { - Temperatures of feed } \\
\text { and permeate: } 55^{\circ} \mathrm{C} \text { and } \\
25^{\circ} \mathrm{C} \\
\text { - DCMD } \\
\text { - PTFE flat sheet } \\
\text { membrane }\end{array}$ & $\begin{array}{l}\text { - The FO-MD hybrid system almost } \\
\text { completely rejected contaminants in } \\
\text { urine. } \\
\text { - Contaminants were accumulated } \\
\text { in DS. } \\
\text { - The hybrid system could produce } \\
\text { higher quality water than MD } \\
\text { alone. }\end{array}$ & [197] \\
\hline Human urine & $\begin{array}{l}\text { - Water flux: } 32 \mathrm{LMH} \\
\text { for fresh urine and } 28 \\
\text { LMH for stored urine } \\
\text { - DS: } 2.5 \mathrm{M} \mathrm{NaCl} \\
\text { - AL-FS mode } \\
\text { - TFC PA FO } \\
\text { membrane }\end{array}$ & $\begin{array}{l}\text { - Water flux: } 10.5 \mathrm{LMH} \\
\text { for PVDF and } 16 \mathrm{LMH} \\
\text { for PTFE } \\
\text { - Specific nitrogen flux: } \\
23 \mathrm{~g} / \mathrm{L} \text { for PVDF and } 8 \\
\mathrm{~g} / \mathrm{L} \text { for PTFE } \\
\text { - FS: } 1.5 \mathrm{M} \mathrm{NaCl} \\
\text { - Temperatures of feed } \\
\text { and permeate: } 60^{\circ} \mathrm{C} \text { and } \\
25^{\circ} \mathrm{C} \\
\text { - DCMD } \\
\text { - PTFE and PVDF flat } \\
\text { sheet membrane }\end{array}$ & $\begin{array}{l}\text { - Back-pressure on DS mitigate the } \\
\text { forward flux of Urea in FO. } \\
\text { - Lower pH reduced the nitrogen } \\
\text { transport in FO. } \\
\text { - PTFE membrane showed better } \\
\text { rejection than PVDF membrane. }\end{array}$ & [226] \\
\hline $\begin{array}{l}\text { Sludge } \\
\text { dewatering }\end{array}$ & $\begin{array}{l}\text { - Water flux: } 8 \sim 6 \\
\text { LMH } \\
\text { - FS: high-nutrient } \\
\text { sludge } \\
\text { - DS: } 0.2 \mathrm{M} \mathrm{Na3PO4} \\
\text { - AL-FS mode } \\
\text { - HTI TFC FO } \\
\text { membrane }\end{array}$ & $\begin{array}{l}\text { - Water flux: } 10.28 \\
\text { LMH } \\
\text { - Rejection: } 100 \% \\
\text { rejection } \\
\text { - Temperatures of feed } \\
\text { and permeate: } 50^{\circ} \mathrm{C} \text { and } \\
25^{\circ} \mathrm{C} \\
\text { - FS: diluted } \mathrm{Na}_{3} \mathrm{PO}_{4} \\
\text { solution } \\
\text { - DCMD } \\
\text { - } 0.45 \mu \mathrm{m} \text { PTFE flat } \\
\text { sheet membrane }\end{array}$ & $\begin{array}{l}\text { - Highly charged phosphate DS } \\
\text { enabled sludge concentrated up to } 6 \\
\text { times. }\end{array}$ & [214] \\
\hline $\begin{array}{l}\text { Direct Sewer } \\
\text { Mining }\end{array}$ & $\begin{array}{l}\text { - Water flux: } 8 \mathrm{LMH} \\
\text { - FS: } 20^{\circ} \mathrm{C} \text { Raw sewage } \\
\text { containing } 12 \mathrm{TrOCs} \\
\text { - DS: } 40^{\circ} \mathrm{C} 1.5 \mathrm{M} \mathrm{NaCl} \\
\text { - AL-FS mode } \\
\text { - HTI CTA FO } \\
\text { membrane }\end{array}$ & $\begin{array}{l}\text { - Water flux: } 8 \mathrm{LMH} \\
\text { - Total rejection: higher } \\
\text { than } 93 \% \\
\text { - Temperatures of feed } \\
\text { and permeate: } 40^{\circ} \mathrm{C} \text { and } \\
20^{\circ} \mathrm{C} \\
\text { - DCMD } \\
\text { - PTFE flat sheet } \\
\text { membrane }\end{array}$ & $\begin{array}{l}\text { - } 80 \% \text { recovery rate was achieved. } \\
\text { - TrOC transport mechanism is } \\
\text { different between FO and MD } \\
\text { membranes. } \\
\text { - Some contaminants in the DS } \\
\text { were accumulated because their } \\
\text { rejection rates of FO and MD } \\
\text { membranes were different. } \\
\text { - Contaminant accumulation in the } \\
\text { DS could be prevented by } \\
\text { employing additional oxidation or } \\
\text { adsorption processes. }\end{array}$ & [227] \\
\hline $\begin{array}{l}\text { Dairy } \\
\text { wastewater }\end{array}$ & $\begin{array}{l}\text { - Water flux: } 8.5 \sim 9.5 \\
\text { LMH and } 6 \sim 10.5 \\
\text { LMH } \\
\text { - Rejection: higher than } \\
95 \% \text { and } 96 \% \text { of TOC, } \\
\text { TN and TP } \\
\text { - FS: Dairy wastewater } \\
\text { - DS: } 1 \mathrm{M} \mathrm{NaCl} \\
\text { - HTI CTA FO } \\
\text { membrane and }\end{array}$ & $\begin{array}{l}\text { - Total rejection: higher } \\
\text { than } 99 \% \\
\text { - Temperatures of feed } \\
\text { and coolant: } 40^{\circ} \mathrm{C} \text { and } \\
20^{\circ} \mathrm{C} \\
\text { - AGMD } \\
\text { - } 0.45 \mu \mathrm{m} \text { PTFE flat } \\
\text { sheet membrane }\end{array}$ & $\begin{array}{l}\text { - The FO-MD hybrid reclaimed } \\
\text { actual DWW up to the level of high } \\
\text { grade utilization. } \\
\text { - Membrane properties, feed quality } \\
\text { and membrane fouling influenced } \\
\text { water flux. } \\
\text { - Membrane cleaning recovered } \\
90 \% \text { of the flux. }\end{array}$ & [236] \\
\hline
\end{tabular}




\begin{tabular}{|c|c|c|c|c|}
\hline & $\begin{array}{l}\text { aquaporin FO } \\
\text { membrane }\end{array}$ & & & \\
\hline $\begin{array}{l}\text { High salinity } \\
\text { landfill } \\
\text { leachate }\end{array}$ & $\begin{array}{l}\text { - Water transfer rate: } \\
0.013 \mathrm{~L} / \mathrm{h} \\
\text { - FS: Simulated } \\
\text { wastewater and landfill } \\
\text { leachates } \\
\text { - DS: } 4.82 \mathrm{M} \mathrm{NaCl} \\
\text { - AL-FS mode } \\
\text { - HTI TFC FO } \\
\text { membrane }\end{array}$ & $\begin{array}{l}\text { - Water transfer rate: } \\
0.009 \mathrm{~L} / \mathrm{h} \\
\text { - Rejection: } 96 \% \\
\text { salinity and } 98 \% \text { toxic } \\
\text { ions } \\
\text { - Temperatures of feed } \\
\text { and permeate: } 62.5^{\circ} \mathrm{C} \\
\text { (or } 72.5^{\circ} \mathrm{C} \text { ) and } 15^{\circ} \mathrm{C} \\
\text { - DCMD } \\
\text { - } 0.45 \mu \mathrm{m} \text { PTFE-PVDF } \\
\text { flat sheet membrane }\end{array}$ & $\begin{array}{l}\text { - Response surface methodology } \\
\text { (RSM) was good at optimizing FO } \\
\text { process. }\end{array}$ & [237] \\
\hline $\begin{array}{l}\text { Flue gas } \\
\text { desulfurization } \\
\text { wastewater }\end{array}$ & $\begin{array}{l}\text { - Water flux: } 20 \text { LMH } \\
\text { - FS: FGD wastewater } \\
\text { - DS: } 3 \mathrm{M} \mathrm{NaCl} \\
\text { - AL-FS mode } \\
\text { - Porifera TFC FO } \\
\text { membrane }\end{array}$ & $\begin{array}{l}\text { - Water flux: } 18 \mathrm{LMH} \\
\text { - Rejection: } 98.61 \% \text {, } \\
99.97 \% \text { and } 99.93 \% \text { of } \\
\text { organics, inorganics, } \\
\text { and particles, } \\
\text { respectively } \\
\text { - FS: Diluted } \mathrm{NaCl} \mathrm{DS} \\
\text { - Temperatures of feed } \\
\text { and permeate: } 55^{\circ} \mathrm{C} \text { and } \\
20^{\circ} \mathrm{C} \\
\text { - DCMD } \\
\text { - } 0.2 \mu \mathrm{m} \text { PTFE flat } \\
\text { sheet membrane }\end{array}$ & $\begin{array}{l}\text { - Significant fouling such as } \mathrm{CaSO}_{4} \\
\text { scaling, appeared in FO. } \\
\text { - In MD, membrane scaling was } \\
\text { observed. } \\
\text { - Proper antiscalant needs to be } \\
\text { proposed to control scaling in both } \\
\text { FO and MD. }\end{array}$ & [204] \\
\hline
\end{tabular}

Table 3 - Summary of potential application (i.e., desalination and other applications) of FO-

MD hybrid systems

\begin{tabular}{|c|c|c|c|c|}
\hline Applications & FO performance & MD performance & Remarks & Ref. \\
\hline $\begin{array}{l}\text { Seawater } \\
\text { desalination }\end{array}$ & $\begin{array}{l}\text { - Water flux: } 9 \text { LMH } \\
\text { - DS: } 33.3 \text { wt \% } \\
\text { poly(amidoamine)- } \\
\text { COONa } \\
\text { - FS: seawater } \\
\text { - AL-FS mode } \\
\text { - HTI TFC FO } \\
\text { membrane. }\end{array}$ & $\begin{array}{l}\text { Water flux: } 3 \mathrm{LMH} \\
- \text { Rejection: } 100 \% \\
\text { - Temperatures of feed } \\
\text { and permeate: } 50^{\circ} \mathrm{C} \text { and } \\
10^{\circ} \mathrm{C} \\
- \text { DCMD } \\
\text { - PVDF hollow fiber } \\
\text { membrane }\end{array}$ & $\begin{array}{l}\text { - PAMAM-COONa is suitable for } \\
\text { FO owing to low viscosity, high } \\
\text { osmotic pressure, and large } \\
\text { molecular size. } \\
\text { - Diluted PAMAM-COONa } \\
\text { solution was readily recovered by } \\
\text { MD. }\end{array}$ & [206] \\
\hline $\begin{array}{l}\text { Seawater } \\
\text { desalination }\end{array}$ & $\begin{array}{l}\text { - Water flux: } 6 \mathrm{LMH} \\
\text { - FS: } 0.6 \mathrm{M} \mathrm{NaCl} \\
\text { - DS: } 60^{\circ} \mathrm{C} 1.5 \mathrm{M} \\
\mathrm{Na} \mathrm{Fe}_{5} \mathrm{CA} \\
\text { - AL-FS mode } \\
\text { - TFC FO membrane }\end{array}$ & $\begin{array}{l}\text { - Water flux: } 30 \mathrm{LMH} \\
\text { - Rejection: } 99.99 \% \\
\text { - FS: } 1.5 \mathrm{M} \text { DS } \\
\text { - Feed temperature: } \\
60^{\circ} \mathrm{C} \\
\cdot \text { DCMD } \\
\cdot 0.2 \mu \mathrm{m} \text { PVDF hollow } \\
\text { fiber membranes }\end{array}$ & $\begin{array}{l}\text { - The hydroacid complex has low } \\
\text { viscosity, high solubility, good } \\
\text { thermal stability and low RSF. }\end{array}$ & [208] \\
\hline $\begin{array}{l}\text { Seawater } \\
\text { desalination }\end{array}$ & $\begin{array}{l}\text { - Water flux: 4.8 LMH, } \\
\text { 4.09 LMH and } 1.74 \\
\text { LMH } \\
\text { - RSF: } 0.53 \mathrm{gMH} \\
\text { - FS: DI water, } 5 \mathrm{~g} / \mathrm{L} \\
\text { and } 35 \mathrm{~g} / \mathrm{L} \\
\text { - DS: } 0.5 \mathrm{M} \mathrm{MgCl} 2 \\
\text { blended with } 0.05 \mathrm{M} \\
\mathrm{Al}_{2}\left(\mathrm{SO}_{4}\right)_{3} \\
\text { - AL-FS mode }\end{array}$ & $\begin{array}{l}\text { - Water flux: } 5.41 \mathrm{LMH} \\
\text { - Rejection: } 99.9 \% \\
\text { - Temperatures of feed } \\
\text { and permeate: } 55^{\circ} \mathrm{C} \text { and } \\
25^{\circ} \mathrm{C} \\
\cdot \text { DCMD } \\
-0.45 \mu \mathrm{m} \text { PTFE flat } \\
\text { sheet membrane }\end{array}$ & $\begin{array}{l}-\mathrm{Al}_{2}\left(\mathrm{SO}_{4}\right)_{3} \text { blended } \mathrm{MgCl}_{2} \mathrm{DS} \text { was } \\
\text { proposed. } \\
\text { - The formation of aluminum } \\
\text { hydroxide in } \mathrm{DS} \text { reduced RSF by } \\
\text { restricting pores. }\end{array}$ & [212] \\
\hline
\end{tabular}




\begin{tabular}{|c|c|c|c|c|}
\hline & $\begin{array}{l}\text { - HTI CTA FO } \\
\text { membrane }\end{array}$ & & & \\
\hline $\begin{array}{l}\text { Seawater } \\
\text { desalination }\end{array}$ & $\begin{array}{l}\text { - Water flux: } 4 \text { LMH } \\
\text { - FS: Simulated } \\
\text { seawater } \\
\text { - DS: PSSS-PNIPAM } \\
\text { - HTI TFC FO } \\
\text { membrane }\end{array}$ & $\begin{array}{l}\text { - Water flux: } 2.7 \mathrm{LMH} \\
\text { - Temperatures of feed } \\
\text { and permeate: } 50^{\circ} \mathrm{C} \text { and } \\
10^{\circ} \mathrm{C} \\
\cdot \text { DCMD } \\
\text { - Multi-bore PVDF } \\
\text { hollow fiber membrane }\end{array}$ & $\begin{array}{l}\text { - The DS osmotic pressure was } \\
\text { thermally controlled. } \\
\text { - The thermoresponsive behavior } \\
\text { facilitated DS regeneration via MD. }\end{array}$ & [219] \\
\hline $\begin{array}{l}\text { Seawater } \\
\text { desalination }\end{array}$ & $\begin{array}{l}\cdot \text { Water flux: } 1.25 \times 10^{-6} \text {, } \\
1.4 \times 10^{-6} \text { and } 4.5 \times 10^{-7} \\
\mathrm{~m} / \mathrm{s} \\
\cdot \text { FS: Simulated } \\
\text { seawater } \\
\cdot \text { DS: } 60^{\circ} \mathrm{C} 4 \mathrm{M} \mathrm{NaCl} \text {, } \\
\mathrm{KCl} \text { and } \mathrm{MgCl}_{2} \\
\text { - AL-FS mode } \\
\text { - HTI CTA FO } \\
\text { membrane }\end{array}$ & $\begin{array}{l}\cdot \text { Water flux: } 7 \times 10^{-6}, \\
6.5 \times 10^{-6} \text { and } 4.4 \times 10^{-6} \\
\mathrm{~m} / \mathrm{s} \\
\cdot \text { Rejection: higher than } \\
99.7 \% \\
\cdot \mathrm{FS}: 0.6,2 \text { and } 4 \mathrm{M} \\
\mathrm{NaCl} \\
\cdot \text { Temperatures of feed } \\
\text { and permeate: } 60 \mathrm{C}^{\circ} \text { and } \\
10^{\circ} \mathrm{C} \\
\cdot \text { DCMD } \\
\cdot \text { PVDF hollow fiber } \\
\text { membrane }\end{array}$ & $\begin{array}{l}\text { - For desalination, draw solutes } \\
\text { should have higher diffusion } \\
\text { coefficients and high } \\
\text { hydrophilicities since they seriously } \\
\text { influenced the performance of the } \\
\text { integrated system. }\end{array}$ & [222] \\
\hline $\begin{array}{l}\text { RO brine } \\
\text { treatment }\end{array}$ & $\begin{array}{l}\text { - Water flux: } 20 \text { LMH } \\
\text { - FS: RO brine } \\
\text { - DS: } 3 \mathrm{M} \mathrm{NaCl} \\
\text { - AL-FS mode } \\
\text { - HTI CTA FO } \\
\text { membrane }\end{array}$ & $\begin{array}{l}\text { - Water flux: } 20 \text { LMH } \\
\text { - Total rejection: } 100 \% \\
\text { - FS: Diluted DS } \\
\text { - Temperatures of feed } \\
\text { and permeate: } 50{ }^{\circ} \mathrm{C} \text { and } \\
20{ }^{\circ} \mathrm{C} \\
\cdot \text { DCMD } \\
\cdot 0.22 \mu \mathrm{m} \text { PTFE flat } \\
\text { sheet membrane }\end{array}$ & $\begin{array}{l}\text { - At higher than temperature } \\
\text { difference of } 20-30^{\circ} \mathrm{C}, \mathrm{MD} \\
\text { exhibited similar water flux to RO. } \\
\text { - When treating real RO brine, } \\
\text { significant flux decline occurred in } \\
\text { both } \mathrm{RO} \text { and } \mathrm{FO} \text {, while water flux } \\
\text { was not seriously decreased in MD. } \\
\text { - Water flux in } \mathrm{MD} \text { was not } \\
\text { affected by } \mathrm{CaCO}_{3} \text { scaling. }\end{array}$ & [126] \\
\hline $\begin{array}{l}\text { Concentration } \\
\text { of protein } \\
\text { solutions }\end{array}$ & $\begin{array}{l}\text { - Water flux: } 5 \mathrm{LMH} \\
\text { - BSA flux: } 17 \mathrm{gMH} \\
\text { - FS: BSA solution } \\
\text { - DS: } 2 \mathrm{M} \mathrm{NaCl} \\
\text { - AL-FS mode } \\
\text { - PBI hollow fiber } \\
\text { membrane }\end{array}$ & $\begin{array}{l}\text { - Water flux: } 15 \mathrm{LMH} \\
\text { - Rejection: } 100 \% \\
\text { - FS: } 2 \mathrm{M} \mathrm{NaCl} \\
\text { - Temperatures of feed } \\
\text { and permeate: } 60^{\circ} \mathrm{C} \text { and } \\
17.5^{\circ} \mathrm{C} \\
\text { - DCMD } \\
\text { - PVDF-PTFE hollow } \\
\text { fiber membrane }\end{array}$ & $\begin{array}{l}\text { - A FO-MD hybrid system } \\
\text { concentrated (BSA) solution. } \\
\text { - Due to similar water production } \\
\text { rate in both FO and MD, the system } \\
\text { could be stably and continuously } \\
\text { operated. }\end{array}$ & [238] \\
\hline $\begin{array}{l}\text { Juice } \\
\text { concentration }\end{array}$ & $\begin{array}{l}\text { - Water flux: } 5 \text { LMH } \\
\text { - FS: } 100 \% \text { apple juice } \\
\text { - DS: } 2 \text { M Potassium } \\
\text { sorbate } \\
\text { - AL-FS and AL-DS } \\
\text { modes } \\
\text { - TFC PA membrane }\end{array}$ & $\begin{array}{l}\text { Water flux: } 5 \text { LMH } \\
\text { - Distillate conductivity: } \\
30 \mu \mathrm{S} \\
\text { - FS: } 2 \text { M Potassium } \\
\text { sorbate } \\
\text { - Temperatures of feed } \\
\text { and permeate: } 25^{\circ} \mathrm{C} \text { and } \\
20^{\circ} \mathrm{C} \\
\text { - DCMD } \\
\text { - PVDF-HFP MD } \\
\text { membrane }\end{array}$ & $\begin{array}{l}\text { - A continuous FO-MD hybrid } \\
\text { system concentrated } 100 \% \text { apple } \\
\text { juice. } \\
\text { - FO and MD fluxes were stable at } \\
5 \text { LMH. } \\
\text { - The accumulated amount of } \\
\text { potassium sorbate was below the } \\
\text { limitation. }\end{array}$ & [239] \\
\hline Heavy metals & $\begin{array}{l}\text { - Water flux: } 5 \sim \\
6 \text { LMH } \\
\text { - Rejection: } 97 \% \\
\text { rejection of heavy } \\
\text { metals } \\
\text { - FS: } 10 \text { ppb } \mathrm{Hg}, \mathrm{Cd} \text { and } \\
\text { Pb solutions } \\
\text { - DS: } 1 \mathrm{M} \mathrm{NaCl}\end{array}$ & $\begin{array}{l}\text { - Water flux: } 7.7 \mathrm{LMH} \\
\text { - Total rejection: almost } \\
100 \% \\
\text { - FS: } 0.5 \mathrm{M} \mathrm{NaCl} \text { and } 1 \\
\text { ppb Hg } \\
\text { - Temperatures of feed } \\
\text { and permeate: } 55^{\circ} \mathrm{C} \text { and } \\
20^{\circ} \mathrm{C}\end{array}$ & $\begin{array}{l}\text { - The governing rejection } \\
\text { mechanism was diffusion, size } \\
\text { exclusion and Donnan exclusion. } \\
\text { - The FO-MD hybrid system } \\
\text { enhanced Hg removal up to around } \\
100 \% \text { rejection. }\end{array}$ & [240] \\
\hline
\end{tabular}




\begin{tabular}{l|l|l|l|l}
\hline & $\begin{array}{l}\bullet \text { AL-FS mode } \\
\bullet \text { HTI TFC FO } \\
\text { membrane }\end{array}$ & $\begin{array}{l}\bullet \text { DCMD } \\
\bullet \text { PTFE flat sheet } \\
\text { membrane }\end{array}$ & & \\
\hline
\end{tabular}

\subsubsection{FO-MD hybrid system design}

The FO-MD hybrid system consists of two separate loops with respective FO and MD modules, where the FO DS collected in the DS tank is fed to the MD module. Using ammonium bicarbonate as DS, Koo et al. [244] evaluated various operating parameters to optimize the system, including DS concentration, operation time and temperature. Despite the optimization, the resulting configuration has several disadvantages such as a large footprint. Prior work by Cath et al. [245] suggests an interesting low-cost integrated design (Fig. 10a) combining FO and MD sealed in a single module, offering compactness and small footprint. This unique module provides the complementary features of FO and MD in a single step [223, 235]. However, this hybrid system presents a configuration drawback since FO DS and MD FS flow in the same channel, which reduces the performance of both processes. To overcome these issues, Ghaffour et al. [246] and Kim et al. [247] suggested an osmotically and thermally isolated FO-MD integrated module (Fig. 10b). The latter comprises two separated flow channels for FO DS and MD feed streams respectively, using an isolation barrier inserted inside the module with an opening on the top, allowing MD brine (MD outlet) to run in the FO DS inlet side, thus maximizing driving forces and reaching higher efficiency for both processes. Optimum conditions of the integrated FO-MD large scale-module have been reported by Kim et al. [247]. Furthermore, the isolation barrier can be optimized to provide turbulence by employing different geometries, e.g. sinusoidal, zigzag, twisted helical baffles, to enhance the process performance by decreasing the temperature and concentration polarization [246]. An in depth economic analysis of the FO-MD integrated module should be conducted to evaluate how much improvement can be brought to its energy-efficiency. 



Fig. 10 Schematic diagram of (a) a FO-MD integrated module $[223,245]$ and (b) an osmotically and thermally isolated FO-MD integrated module [246, 247]. An isolation barrier is inserted inside the module to separate FO DS and MD feed streams allowing both FO and MD processes to operate under optimum conditions, i.e. higher DS concentration and higher feed temperature, respectively).

\subsection{PRO-MD hybrid}

Salinity-gradient energy, also called osmotic power, is an attractive renewable and ecofriendly energy, generated via the release of free energy when blending solutions with concentration gradient (e.g., river water and seawater) [248]. To harness salinity-gradient energy, PRO was firstly proposed by Loeb et al. in 1976 [249]. In PRO, a semipermeable membrane is used to separate a FS from a pressurized and more concentrated DS. The DS can extract pure water through the semipermeable membrane because of its higher chemical potential, resulting in an increased DS volume. Then, a turbine is combined with DS to generate power [250]. However, in spite of high theoretical potential [251], pairing river water and seawater will not produce net energy in PRO since the specific extractable energy will not reach the energy input for the operation [252]. However, use of higher concentration differences (e.g., hypersaline water and fresh water) can be potentially viable since its theoretical energy will remarkably exceed that of river water and seawater system [252].

MD is well suited to concentrate saline solutions since its operation is not sensitive to salinity change [34]. For example, Gryta [178] concentrated $\mathrm{NaCl}$ solution from $10 \mathrm{~g} / \mathrm{m}^{3}$ to 320 $\mathrm{g} / \mathrm{m}^{3}$ using DCMD integrated with crystallization. Kezia et al. [253] concentrated saline dairy effluent from $10 \% \mathrm{w} / \mathrm{w}$ to $30 \% \mathrm{w} / \mathrm{w}$ via DCMD. Therefore, concentrating saline water by MD can enable PRO by increasing the concentration gradient. As shown in Fig. 11a, MD not only 
concentrates saline water but also produces drinkable water. Concentrated saline water can be pressurized with either a pressure exchanger or a high-pressure pump prior to PRO and electricity is generated via a turbine after PRO. Lee et al. [254] proposed and evaluated a multistage VMD and PRO hybrid process to produce power as well as fresh water. They achieved a maximum power density of $9.7 \mathrm{~W} / \mathrm{m}^{2}$ with river water as FS and concentrated brine as DS. In addition, an RO-MD-PRO hybrid process was developed to reduce the energy consumption and the brine concentration. Kim et al. [255] conducted the numerical simulation for the performance of a pilot-scale PRO-hybrid system. They found out that the supply price of the heat source is a critical part for process efficiency, which enables the PRO-hybrid process to surpass stand-alone RO for a reduction of both environmental footprint and SEC. In case of $10 \%$ paid MD heat supply, SEC would increase beyond $80 \mathrm{kWh} / \mathrm{m}^{3}$, which is much higher than $1.78 \mathrm{kWh} / \mathrm{m}^{3}$ at free MD heat supply. Chae et al. [256] suggested a new performance index, defined as the ratio of the energy production to the energy consumption to reflect energy efficiency of the RO-MD-PRO hybrid system. The new index indicated that high total recovery rate leads to high energy efficiency regardless of the cost of the heat source. Han et al. [257] demonstrated experimentally the feasibility of the PRO-MD hybrid process with highly concentrated DS. They could achieve, with $2 \mathrm{M} \mathrm{NaCl} \mathrm{DS}$, power densities of $9.3 \mathrm{~W} / \mathrm{m}^{2}$ and $31 \mathrm{~W} / \mathrm{m}^{2}$ with real wastewater brine and DI water as feeds, respectively. They also suggested that the use of solar energy or low-grade waste heat to heat up the FS and the employment of a heat exchanger might reduce energy consumption (e.g., US\$1.0 - US\$1.4 per $\mathrm{m}^{3}$ for MD desalination systems [37]). 



Fig. 11 Schematic diagrams of (a) a PRO-MD hybrid process, (b) an osmotic heat engine $(\mathrm{OHE})$ and (c) a thermo-osmotic energy conversion (TOEC) process.

McGinnis et al. [258] firstly introduced a concept of a closed-loop osmotic heat engine (OHE), later integrated with MD by Lin et al. [259] (see Fig. 11b), The system consists of a power production stage, that converts the energy released when blending two streams having the concentration gradient into beneficial work. It includes a MD stage to re-generate two streams with low and high concentrations, respectively, using low temperature heat energy. Then two streams are provided to the first stage for energy production. They emphasized that OHE could obtain a theoretical energy efficiency of $9.8 \%$ at $1 \mathrm{M} \mathrm{NaCl}$ and $60{ }^{\circ} \mathrm{C}$ and $20{ }^{\circ} \mathrm{C}$, respectively, while higher working concentration can improve energy efficiency. Shaulsky et al. [260] suggested an organic solvent as DS to enhance the energy efficiency $(2.8 \%$ at $2 \mathrm{M}$ LiCl-Methanol DS and 90\% heat recovery) as well as power density (maximum $72.1 \mathrm{~W} / \mathrm{m}^{2}$ at 3 M LiCl-Methanol DS) of OHE. Methanol was considered as a solvent due to its lower enthalpy of vaporization and heat capacity and higher volatility compared to water, enhancing the thermal separation efficiency of the DS. Hickenbottom et al. [261] evaluated eight ionic organic and inorganic draw solutes to further optimize OHE. They considered RSF, MD water flux, thermal efficiency, and PRO power density. They demonstrated that sodium propionate, $\mathrm{MgCl}_{2}, \mathrm{CaCl}_{2}$, and $\mathrm{LiCl}$ are most suitable DS owing to the lowest risk of corrosion and the 
lowest price of the electricity generation. The techno-economic analysis results showed that the OHE electricity production price is $\$ 0.48$ per $\mathrm{kWh}$, which is much higher than electricity price of $\$ 0.04 / \mathrm{kWh}$ in USA [262]. They suggested that power density in PRO should be improved for a reduction of electricity production price by OHE, implying that highly selective, permeable and mechanically stable PRO membranes should be developed. Interestingly, high feed temperature reduces the system efficiency in spite of increased water flux because more heat energy is required. Furthermore, they carried out a comparative life-cycle assessment of Organic Rankine Cycle (ORC) and OHE for electricity production from low-grade heat and found out that the OHE has more significant environmental impacts in the construction and operation stages than ORC [263]. However, they also concluded that improving membrane module performance and PRO membranes could reduce environmental impacts by $80 \%$.

In addition to PRO-MD hybrid process and OHE, Straub et al. [264] proposed a novel Thermo-Osmotic Energy Conversion (TOEC) process, which consists of an in-situ combination of two novel processes, MD and PRO, to be carried out in a single stage. As presented in Fig. 11c, the TOEC process consists of two separate chambers intended for feed water and pure permeate water. This converts a low-grade heat energy into mechanical energy by inducing a thermo-osmotic vapor flux from a hot feed stream to a pressurized permeate stream across hydrophobic nano-porous membrane. Straub and Elimelech [265] investigated performance limiting effects and energy efficiency in TOEC using low-grade heat and optimized the TOEC process to improve the energy conversion efficiency up to $4.1 \%$ under 50 bars and $60{ }^{\circ} \mathrm{C}$ and $20{ }^{\circ} \mathrm{C}$, respectively. They identified the most important membrane properties (i.e., high pressure resistance, high porosity, an asymmetric pore structure, and a thickness of $30 \mu \mathrm{m}$ to $100 \mu \mathrm{m}$ ) for high performance. The authors emphasized on beneficial operation factors such as high heat exchanger efficiencies, hydrodynamic mixing inside the module and deaerated water streams. Park et al. [266] investigated another hybrid variant termed pressure retarded MD (PRMD) to simultaneously produce both water and electricity. Results showed that the PRMD process can reduce operation cost $\left(0.174 \mathrm{kWh} / \mathrm{m}^{3}\right)$ by generating electricity even though water flux is lower (3\% loss) than the one offered by a DCMD process. Among three hybrid configurations presented in Fig. 11, TOEC (also called as PRMD) is of particular interest because of the simultaneous production of clean water and electricity in a single step. PRO-MD hybrid can produce both water and electricity but this system consists of two processes, which requires higher CAPEX while OHE can produce only electricity even in two separate steps. 


\section{OTHER MD HYBRIDS}

New types of MD treatment systems combined with electrodialysis (ED-MD) [267] or electrocoagulation (EC-MD) [268] have recently emerged. In these systems, ED and EC modules were used for wastewater pretreatment before its desalination in the MD module. The ED is generally used for separation or recovery of valuable products from industrial liquid wastes, including acids and metals [269]. In the ED-MD system (Fig. 12), used for the treatment of acidic wastewater containing $\mathrm{HNO}_{3}$ and $\mathrm{Ce}^{4+}$ ions, ED was employed to recover acid while the VMD module equipped with hydrophobic hollow fiber membranes was used for $\mathrm{Ce}^{4+}$ concentration and water purification. A stable system performance was achieved by varying operating conditions reaching high recovery of $\mathrm{NO}_{3}^{-}(60 \%)$ and $\mathrm{Ce}^{4+}(99.9 \%)$. According to energy efficiency analysis, $>90 \%$ of the overall consumed energy in the ED-MD system belonged to the VMD subsystem, with $0.6 \mathrm{Wh}$ per 1 mole of $\mathrm{HNO}_{3}$ recovery and $78 \mathrm{Wh}$ per $1 \mathrm{~L}$ of permeate produced in the subsystem. Sardari et al. [268] used batch EC process to pretreat hydraulic fracturing high salinity produced water in order to remove organic/oil contaminants and suspended solids which may impair performance of the MD membrane. In optimum conditions ( $3 \mathrm{~A}$ of applied current and $3 \mathrm{~s}$ residence time), the turbidity, TDS and TOC values were decreased by $96 \%, 91 \%$ and $61 \%$, respectively. The EC-pretreated water was further concentrated in continuous DCMD system with a stable permeate flux in a range of 30$33 \mathrm{~L} / \mathrm{m}^{2} \mathrm{~h}$ so that TDS in feed water increased from $135 \mathrm{~g} / \mathrm{L}$ to $265 \mathrm{~g} / \mathrm{L}$ after $434 \mathrm{~h}$ of operation.

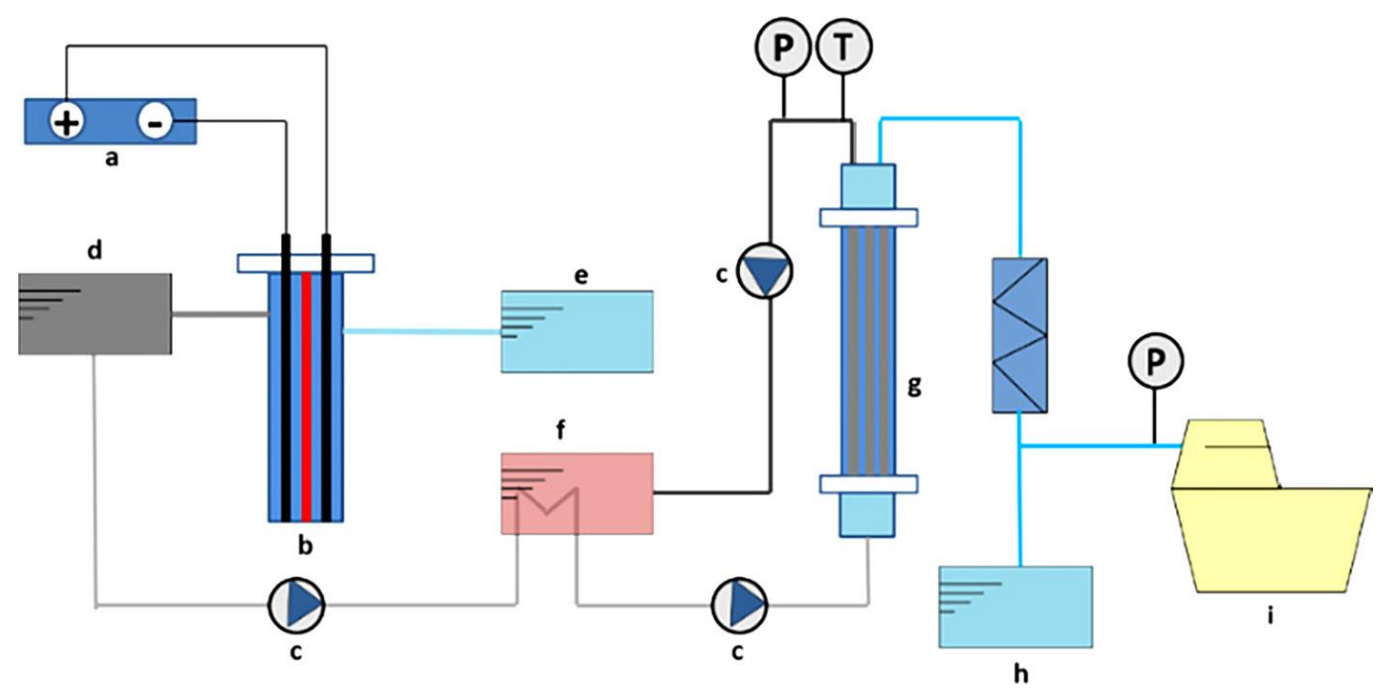


Fig. 12 Schematic of the ED-MD system: : a) direct current power supply, b) ED reactor, c) pump, d) ED feed tank, e) acid tank, f) VMD feed tank, g) VMD membrane module, h) permeate tank, i) vacuum pump [267].

\section{HYBRIDIZATION CURRENT TRENDS AND PERSPECTIVES}

In order to assess the trend of MD hybridization and draw expected perspectives, a thorough compilation of all existing investigations is carried out. The graph of Fig. 13 gives an overview of the scientific literature dedicated to each of the existing MD hybrids. Early investigations, which usually represent a proof of concept, started in 1998. It takes between five and ten years for the concept to gain attractiveness and momentum as it is often encountered in process development. Even though the number of articles per hybrid remains low compared to the total articles production related to $\mathrm{MD}$, a clear interest among the scientific and engineering community is observed during the last five years.

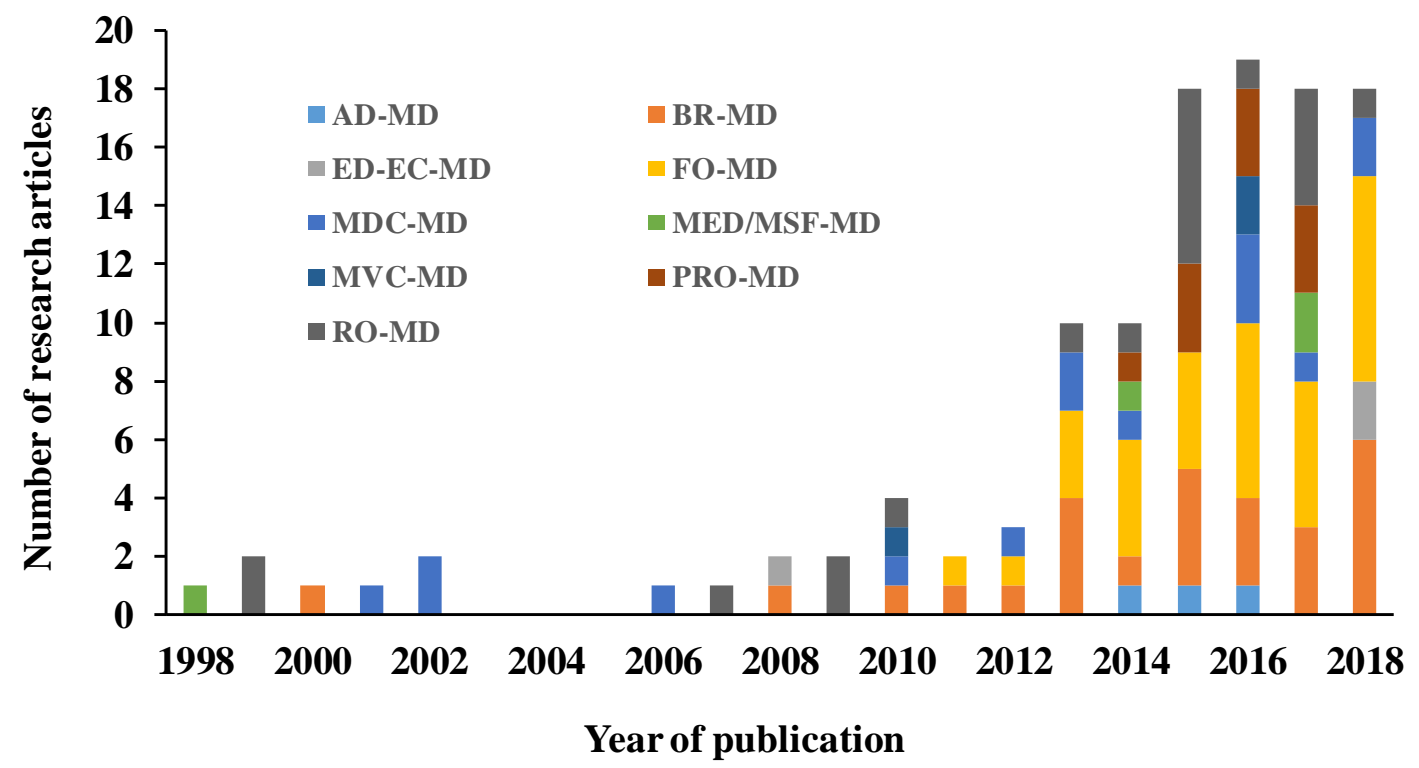

Fig. 13 Evolution of MD hybrids scientific contributions

It is well understood that the high specific thermal energy consumption stands among the limitations for a successful industrialization of the MD process, while the main advantage remains its low sensitivity to feed concentration and water quality variation, and to some extent its ability to operate under intermittent energy supply [16, 271]. Its current status makes it 
suitable for a full integration with established desalination processes to reach near zero liquid discharge and higher performance but also to boost their thermodynamic limits by using appropriate integration systems. Therefore, integration with MED-MSF or RO seems a natural choice as it could be done without any remediation requirement. Although MD water production in series with these processes decreases slightly due to the increase of the inlet feed concentration, a hybrid process can achieve near zero liquid discharge and significantly reduce the environmental impact on marine eco-systems. The low volume discharge of the produced highly concentrated brine can be carried out into a solar pond, or a crystallizer, thus reducing the energy demand and footprint of the crystallization process. However, Fig.13 suggests that the highest interest rather lies within emerging processes such as FO-MD and BR-MD, which represent the largest area in the figure. Will MD hybrids mainly replace major desalination and water treatment technologies or will they only be used as additional steps in a given process flow to enhance throughput? FO-MD and BR-MD fall within the first perspective for desalination and water treatment and face a much bigger challenge. Regarding FO-MD, up to now, all investigations showed that MD successfully re-concentrate different types of DS, which enhances feasibility and stability of FO-MD hybrids. However, despite the dedicated efforts to develop a suitable DS for FO-MD hybrid system, focus was set only on improving FO performance while MD was simply employed to re-concentrate the diluted DS and produce pure water. Therefore, DS should be rethought to have better performances of both FO and MD at high temperature. Even though all studies have proven that the FO-MD hybrid system is appropriate for treating highly contaminated wastewater, an economic analysis need to be carried out to further assess its financial viability and highlight clear targets and set milestones for its future development. Moreover, only lab-scale integrated modules were investigated and their performance will possibly differ from real-scale systems. Careful momentum, heat and mass transfer based scale-up procedures have to be carried out to design pilot scale systems for further evaluations. Regarding BR-MD, the high efficiency of these hybrids with respect to high removal efficiency in treating municipal and wastewaters of different origins has been proven in the experimental studies of this literature review. However, volatile organic compounds produced by the biotransformation processes accumulate in the feed water and increasing the feed temperature enhances their vaporization, which increases their passage through the membrane. As such, further studies should address this issue if high quality water in compliance with the current standards is to be produced with BR-MD. Another important issue, which has not been systematically investigated, is the stability of the MD membranes in 
long-term operations. Indeed, membrane fouling caused by highly concentrated feed water will not only reduce the vapor flux across the membrane but also promote diffusion of the nonvolatile organic compounds onto permeate side due to possible membrane wetting. However, most studies utilize flat sheet DCMD configurations. One of the potential ways to alleviate the reduction of vapor fluxes is the replacement of the flat sheet MD modules with hollow fiberbased arrangements. The new generation of hydrophobic hollow fiber membranes and improved potting technologies emerging on the market (e.g., Eclipse Hollow Fiber Membrane ${ }^{\circledR}$ offered by Markel Corporation, USA), could enable the manufacturing of MD units with high packing density. This is expected to not only boost the permeate flux by fitting larger number of fibers per unit area, but also enhance the process cost-efficiency by reducing the process equipment footprint. A significant knowledge gap exists regarding the type of the MD process used in BR-MD hybrid. To the best of our knowledge, there is no information available so far regarding application of AGMD, VMD or SGMD processes in the BR-MD hybrids. Given the advantages of these configurations over DCMD (e.g., lower heat losses, application of vacuum to enhance the driving force, possibility of using low grade water as a coolant, etc.), there is a need to comprehensively evaluate their efficiency in treating biologically-active waste feeds with high organic content.

Less attention is currently given to MDC-MD. An analysis of the existing literature shows that MDC is an effective technique for freshwater production while recovering valuable compounds from the produced waters and brines. However, high energy consumption remains one of the significant drawbacks of this technology which may potentially impede its wide application. Coupling MDC with solar energy or waste heat sources are possible ways of increasing process cost-efficiency. Another aspect, which needs to be addressed, is that despite promising results achieved in bench scale studies, long-term systematic evaluation of MDC technology at full-scale in terms of process efficiency and economic viability is required to assess its potential in waste management and mitigation of environmental pollution. As of PRO-MD configurations, MD plays a crucial role to increase energy production or directly convert thermal energy into mechanical energy. Therefore, finding the heat source is necessary to enhance the efficiency. There are many wastewater sources with low/mid temperature such as produced water and wastewater from power plants. Further consideration of these sources should be addressed for the successful application of PRO-MD hybrid. Regarding more recent hybrids such as EC-MD, ED-MD and AD-MD, investigations are still at their early stages and 
future research efforts will undoubtedly unveil their intrinsic capabilities in replacing current technologies.

\section{Conclusion}

The growing demand for industrial water reclamation and ZLD policy has intensified development of treatment trains and retention systems to accommodate these requirements and produce high quality fresh water. Within this scope, hybridization is gaining much interest, offering new ways for process improvement an energy saving. This review is twofold, as it provides an actual description of $\mathrm{MD}$, highlighting its advantages and emphasizing its drawbacks while presenting the state of the art of MD hybridization with major water treatment and desalination technologies, with focus set on the complementarity of the processes involved aiming to enhance the total water production and the overall energy efficiency. RO-MD hybrid viability is clearly highlighted in literature and shows that MD is able to alleviate RO limitations when treating concentrated feeds. However, chemical additives used in RO alter MD efficiency and the hybrid necessitates further improvement. Similarly, BR-MD exhibits a clear improvement over sole BR with rejection of compounds recalcitrant to biodegradation, with the latter further improved with unused MD heat. The highest impact of hybridization seems to lie mostly in MED/MSF-MD systems. Indeed, the significant amount of waste heat from the thermal processes associated with relatively hot brines allow running MD at a relatively low cost. However, chemicals used in desalination still affect MD membrane performance. Interestingly, optimized MDC systems performed very well at bench scale, with a proven potential recovering efficiently salts and solids. Full-scale long-term operation deserve additional investigations to confirm economic viability. Beyond MD intensification with MVC, hybridization was carried out with emerging technologies such as AD. The hybrid system deserves additional investigation as it delivered a higher water production, recovery rate and better energy efficacy. Intensive research efforts were carried out to assess FO-MD. The ability of MD to regenerate DS led to abundant literature tackling a large span of applications with different types of DS. Long-term hybrid process operation has yet to be tested at larger scale to assess potential problems including membrane fouling. To a lesser extent, PRO-MD was investigated for the ability of MD to produce concentrated solutions necessary for PRO to produce renewable gas emission free energy. More recent hybrids such as ED-MD and EC-MD were considered for the ability of ED and EC to pretreat feed by removing chemical and species that are potentially harmful to the membrane. Current status of MD 
hybrids shows that systems have to be tested for longer periods and taken to an upper-scale to further assess their feasibility and unveil any potential issue. Main properties that guarantee enhancement of hybrid performance consist mostly in the ability of MD to handle highly concentrated solutions in a hybrid system that provides waste heat. A better evaluation of each hybrid energy demand and the contribution of every component of the process will help reduce their specific energy consumption and set targeted energy optimization investigations. Current literature suggests that MD hybridization is very likely to experience significant advances in near future.

\section{ACKNOWLEDGEMENTS}

The research reported in this paper was supported by funding from King Abdullah University of Science and Technology (KAUST), Saudi Arabia.

\section{REFERENCES}

[1] Progress on drinking-water, sanitation and hygiene. Geneva, Switzerland: World Health Organization; 2017.

[2] The United Nations World Water Development Report. Paris, France: United Nations Educational, Scientific and Cultural Organization; 2019.

[3] Plappally AK, Lienhard V JH. Energy requirements for water production, treatment, end use, reclamation, and disposal. Renewable and Sustainable Energy Reviews. 2012;16:4818-48.

[4] Ang WL, Mohammad AW, Hilal N, Leo CP. A review on the applicability of integrated/hybrid membrane processes in water treatment and desalination plants. Desalination. 2015;363:2-18.

[5] Ghaffour N, Missimer TM, Amy GL. Technical review and evaluation of the economics of water desalination: Current and future challenges for better water supply sustainability. Desalination. 2013;309:197-207.

[6] Hamed OA. Overview of hybrid desalination systems - current status and future prospects. Desalination. 2005;186:207-14.

[7] Ludwig H. Hybrid systems in seawater desalination-practical design aspects, present status and development perspectives. Desalination. 2004;164:1-18.

[8] Amy G, Ghaffour N, Li Z, Francis L, Linares RV, Missimer T, et al. Membrane-based seawater desalination: Present and future prospects. Desalination. 2017;401:16-21.

[9] Lawson KW, Lloyd DR. Membrane distillation. Journal of membrane Science. 1997;124:125. 
[10] Ghaffour N, Bundschuh J, Mahmoudi H, Goosen MF. Renewable energy-driven desalination technologies: A comprehensive review on challenges and potential applications of integrated systems. Desalination. 2015;356:94-114.

[11] Banat F, Jumah R, Garaibeh M. Exploitation of solar energy collected by solar stills for desalination by membrane distillation. Renewable Energy. 2002;25:293-305.

[12] Blanco Gálvez J, García-Rodríguez L, Martín-Mateos I. Seawater desalination by an innovative solar-powered membrane distillation system: the MEDESOL project. Desalination. 2009;246:567-76.

[13] Kim Y-D, Thu K, Ghaffour N, Choon Ng K. Performance investigation of a solar-assisted direct contact membrane distillation system. Journal of Membrane Science. 2013;427:345-64.

[14] Ghaffour N, Reddy VK, Abu-Arabi M. Technology development and application of solar energy in desalination: MEDRC contribution. Renewable and Sustainable Energy Reviews. 2011;15:4410-5.

[15] Bundschuh J, Ghaffour N, Mahmoudi H, Goosen M, Mushtaq S, Hoinkis J. Low-cost lowenthalpy geothermal heat for freshwater production: Innovative applications using thermal desalination processes. Renewable and Sustainable Energy Reviews. 2015;43:196-206.

[16] Lee J-G, Kim W-S, Choi J-S, Ghaffour N, Kim Y-D. Dynamic solar-powered multi-stage direct contact membrane distillation system: Concept design, modeling and simulation. Desalination. 2018;435:278-92.

[17] Banat F, Jwaied N, Rommel M, Koschikowski J, Wieghaus M. Desalination by a "compact SMADES" autonomous solarpowered membrane distillation unit. Desalination. 2007;217:2937.

[18] Qtaishat MR, Banat F. Desalination by solar powered membrane distillation systems. Desalination. 2013;308:186-97.

[19] Sarbatly R, Chiam C-K. Evaluation of geothermal energy in desalination by vacuum membrane distillation. Applied Energy. 2013;112:737-46.

[20] Khayet M, Matsuura T. Membrane Distillation: Principles and Application. The Netherlands: Elsevier; 2011.

[21] Alkhudhiri A, Darwish N, Hilal N. Membrane distillation: A comprehensive review. Desalination. 2012;287:2-18.

[22] Curcio E, Drioli E. Membrane distillation and related operations - a review. Separation and Purification Reviews. 2005;34:35-86.

[23] Zolotarev P, Ugrozov V, Volkina I, Nikulin V. Treatment of waste water for removing heavy metals by membrane distillation. Journal of hazardous materials. 1994;37:77-82.

[24] Kullab A, Martin A. Membrane distillation and applications for water purification in thermal cogeneration plants. Separation and Purification Technology. 2011;76:231-7. 
[25] Zakrzewska-Trznadel G, Harasimowicz M, Chmielewski AG. Concentration of radioactive components in liquid low-level radioactive waste by membrane distillation. Journal of Membrane Science. 1999;163:257-64.

[26] Khayet M. Treatment of radioactive wastewater solutions by direct contact membrane distillation using surface modified membranes. Desalination. 2013;321:60-6.

[27] Liu H, Wang J. Treatment of radioactive wastewater using direct contact membrane distillation. Journal of hazardous materials. 2013;261:307-15.

[28] Calabro V, Jiao BL, Drioli E. Theoretical and experimental study on membrane distillation in the concentration of orange juice. Industrial \& engineering chemistry research. 1994;33:1803-8.

[29] Nene S, Kaur S, Sumod K, Joshi B, Raghavarao K. Membrane distillation for the concentration of raw cane-sugar syrup and membrane clarified sugarcane juice. Desalination. 2002;147:157-60.

[30] Hausmann A, Sanciolo P, Vasiljevic T, Kulozik U, Duke M. Performance assessment of membrane distillation for skim milk and whey processing. Journal of dairy science. 2014;97:56-71.

[31] Adham S, Hussain A, Matar JM, Dores R, Janson A. Application of Membrane Distillation for desalting brines from thermal desalination plants. Desalination. 2013;314:101-8.

[32] Basha SAK. Membrane distillation test for concentration of RO brine. WESSCO - Jeddah, IDA World Congress Perth Convention and Exhibition Centre (PCEC), Perth, Western Australia2011.

[33] Mericq J-P, Laborie S, Cabassud C. Vacuum membrane distillation of seawater reverse osmosis brines. Water Research. 2010;44:5260-73.

[34] Xu J, Singh YB, Amy GL, Ghaffour N. Effect of operating parameters and membrane characteristics on air gap membrane distillation performance for the treatment of highly saline water. Journal of Membrane Science. 2016;512:73-82.

[35] Alkhudhiri A, Darwish N, Hilal N. Produced water treatment: Application of Air Gap Membrane Distillation. Desalination. 2013;309:46-51.

[36] Lee, JG. Alsaadi, AS, Ghaffour, N. Multi-stage air gap membrane distillation reversal for hot impaired quality water treatment: Concept and simulation study. Desalination. 2019;450:111 .

[37] Al-Obaidani S, Curcio E, Macedonio F, Di Profio G, Al-Hinai H, Drioli E. Potential of membrane distillation in seawater desalination: thermal efficiency, sensitivity study and cost estimation. Journal of Membrane Science. 2008;323:85-98.

[38] Winter D. Membrane Distillation: a Thermodynamic, Technological and Economic Analysis [PhD]. Department of Mechanical and Process Engineering, University of Kaiserslautern, Germany: Reiner Lemoine Foundation; 2015. 
[39] González D, Amigo J, Suárez F. Membrane distillation: Perspectives for sustainable and improved desalination. Renewable and Sustainable Energy Reviews. 2017;80:238-59.

[40] Hitsov I, Sitter KD, Dotremont C, Nopens I. Economic modelling and model-based process optimization of membrane distillation. Desalination. 2018;436:125-43.

[41] Swaminathan J, Chung HW, Warsinger DM, AlMarzooqi FA, Arafat HA, Lienhard V JH. Energy efficiency of permeate gap and novel conductive gap membrane distillation. Journal of Membrane Science. 2016;502:171-8.

[42] Alsaadi AS, Alpatova A, Lee J-G, Francis L, Ghaffour N. Flashed-feed VMD configuration as a novel method for eliminating temperature polarization effect and enhancing water vapor flux. Journal of Membrane Science. 2018;563:175-82.

[43] Lee J-G, Alsaadi AS, Karam AM, Francis L, Soukane S, Ghaffour N. Total water production capacity inversion phenomenon in multi-stage direct contact membrane distillation: A theoretical study. Journal of Membrane Science. 2017;544:126-34.

[44] Alsaadi AS, Ghaffour N, Li JD, Gray S, Francis L, Maab H, et al. Modeling of air-gap membrane distillation process: A theoretical and experimental study. Journal of Membrane Science. 2013;445:53-65.

[45] Francis L, Ghaffour N, AlSaadi A, Nunes S, Amy G. PVDF hollow fiber and nanofiber membranes for fresh water reclamation using membrane distillation. Journal of Materials Science. 2014;49:2045-2053.

[46] Alsaadi AS, Francis L, Maab H, Amy GL, Ghaffour N. Evaluation of air gap membrane distillation process running under sub-atmospheric conditions: Experimental and simulation studies. J Membr Sci. 2015;489:73-80.

[47] Francis L, Ghaffour N, Al-Saadi AS, Amy GL. Submerged membrane distillation for seawater desalination. Desalination and Water Treatment. 2015;55:2741-6. Maab H, Alsaadi A, Francis L, Livazovic S, Ghaffour N, Amy GL, Nunes SP. Polyazole hollow fiber membranes for direct contact membrane distillation. Industrial \& Engineering Chemistry Research. 2013;52:10425-10429.

[48] Lee J-G, Kim Y-D, Kim W-S, Francis L, Amy G, Ghaffour N. Performance modeling of direct contact membrane distillation (DCMD) seawater desalination process using a commercial composite membrane. Journal of Membrane Science. 2015;478:85-95.

[49] El-Bourawi M, Ding Z, Ma R, Khayet M. A framework for better understanding membrane distillation separation process. Journal of Membrane Science. 2006;285:4-29.

[50] Schofield R, Fane A, Fell C. Heat and mass transfer in membrane distillation. Journal of membrane Science. 1987;33:299-313.

[51] Cath TY, Adams VD, Childress AE. Experimental study of desalination using direct contact membrane distillation: a new approach to flux enhancement. Journal of Membrane Science. 2004;228:5-16.

[52] Qtaishat M, Matsuura T, Kruczek B, Khayet M. Heat and mass transfer analysis in direct contact membrane distillation. Desalination. 2008;219:272-92. 
[53] Gryta M, Tomaszewska M. Heat transport in the membrane distillation process. Journal of membrane science. 1998;144:211-22.

[54] Alsaadi AS, Francis L, Amy GL, Ghaffour N. Experimental and theoretical analyses of temperature polarization effect in vacuum membrane distillation. Journal of Membrane Science. 2014;471:138-48.

[55] Kyoungjin An A, Lee E-J, Guo J, Jeong S, Lee J-G, Ghaffour N. Enhanced vapor transport in membrane distillation via functionalized carbon nanotubes anchored into electrospun nanofibres. Scientific Reports. 2017;7:41562.

[56] Lawson KW, Lloyd DR. Membrane distillation. I. Module design and performance evaluation using vacuum membrane distillation. Journal of Membrane Science. 1996;120:11121.

[57] Phattaranawik J, Jiraratananon R, Fane A. Heat transport and membrane distillation coefficients in direct contact membrane distillation. Journal of Membrane Science. 2003;212:177-93.

[58] Martínez-Díez L, Vazquez-Gonzalez MI. Temperature and concentration polarization in membrane distillation of aqueous salt solutions. Journal of membrane science. 1999;156:26573.

[59] Srisurichan S, Jiraratananon R, Fane A. Mass transfer mechanisms and transport resistances in direct contact membrane distillation process. Journal of Membrane Science. 2006;277:186-94.

[60] Lawson KW, Lloyd DR. Membrane distillation. II. Direct contact MD. Journal of Membrane Science. 1996;120:123-33.

[61] Schofield R, Fane A, Fell C, Macoun R. Factors affecting flux in membrane distillation. Desalination. 1990;77:279-94.

[62] Ding Z, Ma R, Fane A. A new model for mass transfer in direct contact membrane distillation. Desalination. 2003;151:217-27.

[63] Mengual JI, Khayet M, Godino MP. Heat and mass transfer in vacuum membrane distillation. International Journal of Heat and Mass Transfer. 2004;47:865-75.

[64] Lin S, Yip NY, Elimelech M. Direct contact membrane distillation with heat recovery: Thermodynamic insights from module scale modeling. Journal of Membrane Science. 2014;453:498-515.

[65] Phattaranawik J, Jiraratananon R. Direct contact membrane distillation: effect of mass transfer on heat transfer. Journal of Membrane Science. 2001;188:137-43.

[66] Alklaibi A, Lior N. Heat and mass transfer resistance analysis of membrane distillation. Journal of membrane science. 2006;282:362-9.

[67] Phattaranawik J, Jiraratananon R, Fane AG. Effect of pore size distribution and air flux on mass transport in direct contact membrane distillation. Journal of Membrane Science. 2003;215:75-85. 
[68] Khayet M, Velázquez A, Mengual Juan I. Modelling mass transport through a porous partition: Effect of pore size distribution. jnet. 2004;29:279.

[69] Soukane S, Naceur MW, Francis L, Alsaadi A, Ghaffour N. Effect of feed flow pattern on the distribution of permeate fluxes in desalination by direct contact membrane distillation. Desalination. 2017;418:43-59.

[70] Soukane S, Lee J-G, Ghaffour N. Direct contact membrane distillation module scale-up calculations: Choosing between convective and conjugate approaches. Separation and Purification Technology. 2019;209:279-92.

[71] Qtaishat M, Khayet M, Matsuura T. Novel porous composite hydrophobic/hydrophilic polysulfone membranes for desalination by direct contact membrane distillation. Journal of Membrane science. 2009;341:139-48.

[72] Tijing LD, Woo YC, Johir MAH, Choi J-S, Shon HK. A novel dual-layer bicomponent electrospun nanofibrous membrane for desalination by direct contact membrane distillation. Chemical Engineering Journal. 2014;256:155-9.

[73] Khayet M, Mengual J, Matsuura T. Porous hydrophobic/hydrophilic composite membranes: application in desalination using direct contact membrane distillation. Journal of Membrane Science. 2005;252:101-13.

[74] Cheng DY, Wiersma SJ. Composite membrane for a membrane distillation system. 1983.

[75] Prince JA, Singh G, Rana D, Matsuura T, Anbharasi V, Shanmugasundaram TS. Preparation and characterization of highly hydrophobic poly(vinylidene fluoride) - Clay nanocomposite nanofiber membranes (PVDF-clay NNMs) for desalination using direct contact membrane distillation. Journal of Membrane Science. 2012;397-398:80-6.

[76] Yang X, Wang R, Shi L, Fane AG, Debowski M. Performance improvement of PVDF hollow fiber-based membrane distillation process. Journal of Membrane Science. 2011;369:437-47.

[77] Hendren Z, Brant J, Wiesner M. Surface modification of nanostructured ceramic membranes for direct contact membrane distillation. Journal of Membrane Science. 2009;331:1-10.

[78] Wei X, Zhao B, Li X-M, Wang Z, He B-Q, He T, et al. CF4 plasma surface modification of asymmetric hydrophilic polyethersulfone membranes for direct contact membrane distillation. Journal of membrane science. 2012;407:164-75.

[79] Zuo G, Wang R. Novel membrane surface modification to enhance anti-oil fouling property for membrane distillation application. Journal of membrane science. 2013;447:26-35.

[80] Lee E-J, An AK, He T, Woo YC, Shon HK. Electrospun nanofiber membranes incorporating fluorosilane-coated $\mathrm{TiO} 2$ nanocomposite for direct contact membrane distillation. Journal of Membrane Science. 2016;520:145-54.

[81] Gethard K, Sae-Khow O, Mitra S. Water desalination using carbon-nanotube-enhanced membrane distillation. ACS applied materials \& interfaces. 2010;3:110-4. 
[82] Li B, Sirkar KK. Novel membrane and device for direct contact membrane distillationbased desalination process. Industrial \& engineering chemistry research. 2004;43:5300-9.

[83] Qtaishat M, Rana D, Khayet M, Matsuura T. Preparation and characterization of novel hydrophobic/hydrophilic polyetherimide composite membranes for desalination by direct contact membrane distillation. Journal of membrane science. 2009;327:264-73.

[84] Boo C, Lee J, Elimelech M. Omniphobic polyvinylidene fluoride (PVDF) membrane for desalination of shale gas produced water by membrane distillation. Environmental science \& technology. 2016;50:12275-82.

[85] Chen L-H, Huang A, Chen Y-R, Chen C-H, Hsu C-C, Tsai F-Y, et al. Omniphobic membranes for direct contact membrane distillation: Effective deposition of zinc oxide nanoparticles. Desalination. 2018;428:255-63.

[86] Lin S, Nejati S, Boo C, Hu Y, Osuji CO, Elimelech M. Omniphobic Membrane for Robust Membrane Distillation. Environmental Science \& Technology Letters. 2014;1:443-7.

[87] Woo YC, Chen Y, Tijing LD, Phuntsho S, He T, Choi J-S, et al. CF4 plasma-modified omniphobic electrospun nanofiber membrane for produced water brine treatment by membrane distillation. Journal of Membrane Science. 2017;529:234-42.

[88] Phattaranawik J, Jiraratananon R, Fane A. Effects of net-type spacers on heat and mass transfer in direct contact membrane distillation and comparison with ultrafiltration studies. Journal of membrane science. 2003;217:193-206.

[89] Lee J-G, Jeong S, Alsaadi AS, Ghaffour N. Influence of high range of mass transfer coefficient and convection heat transfer on direct contact membrane distillation performance. Desalination. 2018;426:127-34.

[90] Albeirutty M, Turkmen N, Al-Sharif S, Bouguecha S, Malik A, Faruki O, et al. An experimental study for the characterization of fluid dynamics and heat transport within the spacer-filled channels of membrane distillation modules. Desalination. 2018;430:136-46.

[91] Al-Sharif S, Albeirutty M, Cipollina A, Micale G. Modelling flow and heat transfer in spacer-filled membrane distillation channels using open source CFD code. Desalination. 2013;311:103-12.

[92] Alsaadi A, Ghaffour N, Li J-D, Gray S, Francis L, Maab H, et al. Modeling of air-gap membrane distillation process: a theoretical and experimental study. Journal of Membrane Science. 2013;445:53-65.

[93] Curcio E, Drioli E. Membrane Distillation and Related Operations-A Review. Separation \& Purification Reviews. 2005;34:35-86.

[94] Kim Y-D, Francis L, Lee J-G, Ham M-G, Ghaffour N. Effect of non-woven net spacer on a direct contact membrane distillation performance: Experimental and theoretical studies. Journal of Membrane Science. 2018;564:193-203.

[95] Laganà F, Barbieri G, Drioli E. Direct contact membrane distillation: modelling and concentration experiments. Journal of Membrane Science. 2000;166:1-11. 
[96] Song L, Li B, Sirkar KK, Gilron JL. Direct Contact Membrane Distillation-Based Desalination: Novel Membranes, Devices, Larger-Scale Studies, and a Model. Industrial \& Engineering Chemistry Research. 2007;46:2307-23.

[97] Khayet M, Matsuura T, Mengual J, Qtaishat M. Design of novel direct contact membrane distillation membranes. Desalination. 2006;192:105-11.

[98] Naidu G, Shim WG, Jeong S, Choi Y, Ghaffour N, Vigneswaran S. Transport phenomena and fouling in vacuum enhanced direct contact membrane distillation: Experimental and modelling. Separation and Purification Technology. 2017;172:285-95.

[99] Khayet M, Cojocaru C, García-Payo MdC. Experimental design and optimization of asymmetric flat-sheet membranes prepared for direct contact membrane distillation. Journal of membrane science. 2010;351:234-45.

[100] Singh D, Sirkar KK. Desalination of brine and produced water by direct contact membrane distillation at high temperatures and pressures. Journal of Membrane Science. 2012;389:380-8.

[101] Hou D, Fan H, Jiang Q, Wang J, Zhang X. Preparation and characterization of PVDF flat-sheet membranes for direct contact membrane distillation. Separation and Purification Technology. 2014;135:211-22.

[102] Wang KY, Chung T-S, Gryta M. Hydrophobic PVDF hollow fiber membranes with narrow pore size distribution and ultra-thin skin for the fresh water production through membrane distillation. Chemical Engineering Science. 2008;63:2587-94.

[103] Bonyadi S, Chung TS. Flux enhancement in membrane distillation by fabrication of dual layer hydrophilic-hydrophobic hollow fiber membranes. Journal of membrane science. 2007;306:134-46.

[104] Teoh MM, Bonyadi S, Chung T-S. Investigation of different hollow fiber module designs for flux enhancement in the membrane distillation process. Journal of Membrane Science. 2008;311:371-9.

[105] Bonyadi S, Chung T-S. Highly porous and macrovoid-free PVDF hollow fiber membranes for membrane distillation by a solvent-dope solution co-extrusion approach. Journal of Membrane Science. 2009;331:66-74.

[106] Wang P, Teoh MM, Chung T-S. Morphological architecture of dual-layer hollow fiber for membrane distillation with higher desalination performance. Water research. 2011;45:5489-500.

[107] Winter D, Koschikowski J, Wieghaus M. Desalination using membrane distillation: Experimental studies on full scale spiral wound modules. Journal of Membrane Science. 2011;375:104-12.

[108] Winter D, Koschikowski J, Ripperger S. Desalination using membrane distillation: flux enhancement by feed water deaeration on spiral-wound modules. Journal of membrane science. 2012;423:215-24. 
[109] Duong HC, Chivas AR, Nelemans B, Duke M, Gray S, Cath TY, et al. Treatment of RO brine from CSG produced water by spiral-wound air gap membrane distillation - A pilot study. Desalination. 2015;366:121-9.

[110] Khayet M. Solar desalination by membrane distillation: Dispersion in energy consumption analysis and water production costs (a review). Desalination. 2013;308:89-101.

[111] Lienhard V JH, Mistry KH, Sharqawy MH, Thiel GP. Thermodynamics, Exergy and Energy Efficiency in Desalination Systems. In: Arafat HA, editor. Desalination sustainability: A Technical, Socioeconomic and Environmental Approach: Elsevier Publishing Co.; 2017.

[112] Semiat R. Energy Issues in Desalination Processes. Environmental science \& technology. 2008;42:8193-201.

[113] Zuo G, Wang R, Field R, Fane AG. Energy efficiency evaluation and economic analyses of direct contact membrane distillation system using Aspen Plus. Desalination. 2011;283:23744.

[114] Criscuoli A, Drioli E. Energetic and exergetic analysis of an integrated membrane desalination system. Desalination. 1999;124:243-9.

[115] Geng H, Wang J, Zhang C, Li P, Chang H. High water recovery of RO brine using multistage air gap membrane distillation. Desalination. 2015;355:178-85.

[116] El-Zanati E, El-Khatib KM. Integrated membrane -based desalination system. Desalination. 2007;205:15-25.

[117] Drioli E, Laganà F, Criscuoli A, Barbieri G. Integrated membrane operations in desalination processes. Desalination. 1999;122:141-5.

[118] Zhiqing Y, Xiaolong L, Chunrui W, Xuan W. Effect of pretreatment on membrane fouling and VMD performance in the treatment of RO-concentrated wastewater. Desalination and Water Treatment. 2013;51:6994-7003.

[119] Naidu G, Jeong S, Choi Y, Vigneswaran S. Membrane distillation for wastewater reverse osmosis concentrate treatment with water reuse potential. Journal of Membrane Science. 2017;524:565-75.

[120] Sanmartino JA, Khayet M, García-Payo MC, El-Bakouri H, Riaza A. Treatment of reverse osmosis brine by direct contact membrane distillation: Chemical pretreatment approach. Desalination. 2017;420:79-90.

[121] Zhang P, Knötig P, Gray S, Duke M. Scale reduction and cleaning techniques during direct contact membrane distillation of seawater reverse osmosis brine. Desalination. 2015;374:20-30.

[122] Yan Z, Yang H, Qu F, Yu H, Liang H, Li G, et al. Reverse osmosis brine treatment using direct contact membrane distillation: Effects of feed temperature and velocity. Desalination. 2017;423:149-56.

[123] Qu D, Wang J, Fan B, Luan Z, Hou D. Study on concentrating primary reverse osmosis retentate by direct contact membrane distillation. Desalination. 2009;247:540-50. 
[124] Peng Y, Ge J, Li Z, Wang S. Effects of anti-scaling and cleaning chemicals on membrane scale in direct contact membrane distillation process for RO brine concentrate. Separation and Purification Technology. 2015;154:22-6.

[125] Nguyen Q-M, Jeong S, Lee S. Characteristics of membrane foulants at different degrees of SWRO brine concentration by membrane distillation. Desalination. 2017;409:7-20.

[126] Lee S, Kim Y, Kim AS, Hong S. Evaluation of membrane-based desalting processes for RO brine treatment. Desalination and Water Treatment. 2016;57:7432-9.

[127] Martinetti CR, Childress AE, Cath TY. High recovery of concentrated RO brines using forward osmosis and membrane distillation. Journal of Membrane Science. 2009;331:31-9.

[128] Kharraz JA, Bilad MR, Arafat HA. Flux stabilization in membrane distillation desalination of seawater and brine using corrugated PVDF membranes. Journal of Membrane Science. 2015;495:404-14.

[129] Ge J, Peng Y, Li Z, Chen P, Wang S. Membrane fouling and wetting in a DCMD process for RO brine concentration. Desalination. 2014;344:97-107.

[130] Duong HC, Gray S, Duke M, Cath TY, Nghiem LD. Scaling control during membrane distillation of coal seam gas reverse osmosis brine. Journal of Membrane Science. 2015;493:673-82.

[131] Lee J-G, Jang Y, Fortunato L, Jeong S, Lee S, Leiknes T, et al. An advanced online monitoring approach to study the scaling behavior in direct contact membrane distillation. Journal of Membrane Science. 2018;546:50-60.

[132] Khaing T-H, Li J, Li Y, Wai N, Wong F-s. Feasibility study on petrochemical wastewater treatment and reuse using a novel submerged membrane distillation bioreactor. Separation and Purification Technology. 2010;74:138-43.

[133] Goh S, Zhang J, Liu Y, Fane AG. Fouling and wetting in membrane distillation (MD) and MD-bioreactor (MDBR) for wastewater reclamation. Desalination. 2013;323:39-47.

[134] Goh S, Zhang Q, Zhang J, McDougald D, Krantz WB, Liu Y, et al. Impact of a biofouling layer on the vapor pressure driving force and performance of a membrane distillation process. Journal of Membrane Science. 2013;438:140-52.

[135] Liu C, Chen L, Zhu L. Application of membrane distillation for the treatment of anaerobic membrane bioreactor effluent: An especial attention to the operating conditions. Chemosphere. 2018;208:530-40.

[136] Kim H-C, Shin J, Won S, Lee J-Y, Maeng SK, Song KG. Membrane distillation combined with an anaerobic moving bed biofilm reactor for treating municipal wastewater. Water Research. 2015;71:97-106.

[137] Jacob P, Phungsai P, Fukushi K, Visvanathan C. Direct contact membrane distillation for anaerobic effluent treatment. Journal of Membrane Science. 2015;475:330-9.

[138] Asif MB, Hai FI, Kang J, van de Merwe JP, Leusch FDL, Price WE, et al. Biocatalytic degradation of pharmaceuticals, personal care products, industrial chemicals, steroid hormones 
and pesticides in a membrane distillation-enzymatic bioreactor. Bioresource Technology. 2018;247:528-36.

[139] Asif MB, Nguyen LN, Hai FI, Price WE, Nghiem LD. Integration of an enzymatic bioreactor with membrane distillation for enhanced biodegradation of trace organic contaminants. International Biodeterioration \& Biodegradation. 2017;124:73-81.

[140] Song X, Luo W, McDonald J, Khan SJ, Hai FI, Price WE, et al. An anaerobic membrane bioreactor - membrane distillation hybrid system for energy recovery and water reuse: Removal performance of organic carbon, nutrients, and trace organic contaminants. Science of The Total Environment. 2018;628-629:358-65.

[141] Wijekoon KC, Hai FI, Kang J, Price WE, Guo W, Ngo HH, et al. A novel membrane distillation-thermophilic bioreactor system: Biological stability and trace organic compound removal. Bioresource Technology. 2014;159:334-41.

[142] Phattaranawik J, Fane AG, Pasquier ACS, Bing W. A novel membrane bioreactor based on membrane distillation. Desalination. 2008;223:386-95.

[143] Gryta M, Morawski AW, Tomaszewska M. Ethanol production in membrane distillation bioreactor. Catalysis Today. 2000;56:159-65.

[144] Tomaszewska M, Białończyk L. Production of ethanol from lactose in a bioreactor integrated with membrane distillation. Desalination. 2013;323:114-9.

[145] Pal P, Kumar R, Ghosh AK. Analysis of process intensification and performance assessment for fermentative continuous production of bioethanol in a multi-staged membraneintegrated bioreactor system. Energy Conversion and Management. 2018;171:371-83.

[146] Tomaszewska M, Białończyk L. Ethanol production from whey in a bioreactor coupled with direct contact membrane distillation. Catalysis Today. 2016;268:156-63.

[147] Gryta M, Markowska-Szczupak A, Bastrzyk J, Tomczak W. The study of membrane distillation used for separation of fermenting glycerol solutions. Journal of Membrane Science. 2013;431:1-8.

[148] Pal P, Manna AK. Removal of arsenic from contaminated groundwater by solar-driven membrane distillation using three different commercial membranes. Water Research. 2010;44:5750-60.

[149] Goh S, Zhang J, Liu Y, Fane AG. Membrane Distillation Bioreactor (MDBR) - A lower Green-House-Gas (GHG) option for industrial wastewater reclamation. Chemosphere. 2015;140:129-42.

[150] Khaing TH, Li J, Li Y, Wai N, Wong FS. Feasibility study on petrochemical wastewater treatment and reuse using a novel submerged membrane distillation bioreactor. Separation and Purification Technology. 2010;74:138-43.

[151] Barancewicz M, Gryta M. Ethanol production in a bioreactor with an integrated membrane distillation module. Chemical Papers. 2012;66:85-91. 
[152] Gryta M, Barancewicz M. Separation of volatile compounds from fermentation broth by membrane distillation. 2011;13:56.

[153] Zhang Q, Shuwen G, Zhang J, Fane AG, Kjelleberg S, Rice SA, et al. Analysis of microbial community composition in a lab-scale membrane distillation bioreactor. Journal of Applied Microbiology. 2015;118:940-53.

[154] Morrow CP, Furtaw NM, Murphy JR, Achilli A, Marchand EA, Hiibel SR, et al. Integrating an aerobic/anoxic osmotic membrane bioreactor with membrane distillation for potable reuse. Desalination. 2018;432:46-54.

[155] Shahzad MA, Khan SJ, Siddique MS. Draw solution recovery using direct contact membrane distillation (DCMD) from osmotic membrane bioreactor (Os-MBR). Journal of Water Process Engineering. 2017.

[156] Nguyen NC, Nguyen HT, Chen S-S, Ngo HH, Guo W, Chan WH, et al. A novel osmosis membrane bioreactor-membrane distillation hybrid system for wastewater treatment and reuse. Bioresource Technology. 2016;209:8-15.

[157] Luo W, Phan HV, Li G, Hai FI, Price WE, Elimelech M, et al. An Osmotic Membrane Bioreactor-Membrane Distillation System for Simultaneous Wastewater Reuse and Seawater Desalination: Performance and Implications. Environmental Science \& Technology. 2017;51:14311-20.

[158] Siddique MS, Khan SJ, Shahzad MA, Nawaz MS, Hankins NP. Insight into the effect of organic and inorganic draw solutes on the flux stability and sludge characteristics in the osmotic membrane bioreactor. Bioresource Technology. 2018;249:758-66.

[159] Tomaszewska M, Białończyk L. Influence of proteins content in the feed on the course of membrane distillation. Desalination and Water Treatment. 2013;51:2362-7.

[160] Krzeminski P, van der Graaf JH, van Lier JB. Specific energy consumption of membrane bioreactor (MBR) for sewage treatment. Water Science and Technology. 2012;65:380-92.

[161] Skouterisl G, Arnot TC, Jraou M, Feki F, Sayadi S. Modeling energy consumption in membrane bioreactors for wastewater treatment in north Africa. Water Environment Research. 2014;86:232-44.

[162] Shapiro AP. Vapor compression membrane distillation system and method. 2010.

[163] Pereira RH, Ruetten J, Cinelli BA, Costa ACM. Hybrid vapor compression membrane distillation drive assembly and method of use. USA2016.

[164] Swaminathan J, Nayar KG, Lienhard V JH. Mechanical vapor compression-Membrane distillation hybrids for reduced specific energy consumption. Desalination and Water Treatment. 2016;57:26507-17.

[165] Ghaffour N. The challenge of capacity-building strategies and perspectives for desalination for sustainable water use in MENA. Desalination and Water Treatment. 2009;5:48-53. 
[166] De Andrés MC, Doria J, Khayet M, Peña L, Mengual JI. Coupling of a membrane distillation module to a multieffect distiller for pure water production. Desalination. 1998;115:71-81.

[167] Minier-Matar J, Hussain A, Janson A, Benyahia F, Adham S. Field evaluation of membrane distillation technologies for desalination of highly saline brines. Desalination. 2014;351:101-8.

[168] Bamufleh H, Abdelhady F, Baaqeel HM, El-Halwagi MM. Optimization of multi-effect distillation with brine treatment via membrane distillation and process heat integration. Desalination. 2017;408:110-8.

[169] González-Bravo R, Ponce-Ortega JM, El-Halwagi MM. Optimal Design of Water Desalination Systems Involving Waste Heat Recovery. Industrial \& Engineering Chemistry Research. 2017;56:1834-47.

[170] Semblante GU, Lee JZ, Lee LY, Ong SL, Ng HY. Brine pre-treatment technologies for zero liquid discharge systems. Desalination. 2018;441:96-111.

[171] Tong T, Elimelech M. The Global Rise of Zero Liquid Discharge for Wastewater Management: Drivers, Technologies, and Future Directions. Environmental Science \& Technology. 2016;50:6846-55.

[172] Macedonio F, Curcio E, Drioli E. Integrated membrane systems for seawater desalination: energetic and exergetic analysis, economic evaluation, experimental study. Desalination. 2007;203:260-76.

[173] Bennett RC, Fieldman H, Randolph AD. Crystallizer Influenced Nucleation. Chem Eng Prog. 1973;69:86-93.

[174] Ji X, Curcio E, Al Obaidani S, Di Profio G, Fontananova E, Drioli E. Membrane distillation-crystallization of seawater reverse osmosis brines. Separation and Purification Technology. 2010;71:76-82.

[175] Creusen R, van Medevoort J, Roelands M, van Renesse van Duivenbode A, Hanemaaijer $\mathrm{JH}$, van Leerdam R. Integrated membrane distillation-crystallization: Process design and cost estimations for seawater treatment and fluxes of single salt solutions. Desalination. 2013;323:8-16.

[176] Kim J, Kwon H, Lee S, Lee S, Hong S. Membrane distillation (MD) integrated with crystallization (MDC) for shale gas produced water (SGPW) treatment. Desalination. 2017;403:172-8.

[177] Tun CM, Fane AG, Matheickal JT, Sheikholeslami R. Membrane distillation crystallization of concentrated salts-flux and crystal formation. Journal of Membrane Science. 2005;257:144-55.

[178] Gryta M. Concentration of $\mathrm{NaCl}$ solution by membrane distillation integrated with crystallization. Separation Science and Technology. 2002;37:3535-58.

[179] Curcio E, Criscuoli A, Drioli E. Membrane Crystallizers. Industrial \& Engineering Chemistry Research. 2001;40:2679-84. 
[180] Quist-Jensen CA, Ali A, Mondal S, Macedonio F, Drioli E. A study of membrane distillation and crystallization for lithium recovery from high-concentrated aqueous solutions. Journal of Membrane Science. 2016;505:167-73.

[181] Edwie F, Chung T-S. Development of simultaneous membrane distillationcrystallization (SMDC) technology for treatment of saturated brine. Chemical Engineering Science. 2013;98:160-72.

[182] Shin Y, Sohn J. Mechanisms for scale formation in simultaneous membrane distillation crystallization: Effect of flow rate. Journal of Industrial and Engineering Chemistry. 2016;35:318-24.

[183] Chen G, Lu Y, Krantz WB, Wang R, Fane AG. Optimization of operating conditions for a continuous membrane distillation crystallization process with zero salty water discharge. Journal of Membrane Science. 2014;450:1-11.

[184] Quist-Jensen CA, Macedonio F, Horbez D, Drioli E. Reclamation of sodium sulfate from industrial wastewater by using membrane distillation and membrane crystallization. Desalination. 2017;401:112-9.

[185] Drioli E, Curcio E, Di Profio G, Macedonio F, Criscuoli A. Integrating Membrane Contactors Technology and Pressure-Driven Membrane Operations for Seawater Desalination: Energy, Exergy and Costs Analysis. Chemical Engineering Research and Design. 2006;84:209-20.

[186] Guan G, Wang R, Wicaksana F, Yang X, Fane AG. Analysis of Membrane Distillation Crystallization System for High Salinity Brine Treatment with Zero Discharge Using Aspen Flowsheet Simulation. Industrial \& Engineering Chemistry Research. 2012;51:13405-13.

[187] Julian H, Meng S, Li H, Ye Y, Chen V. Effect of operation parameters on the mass transfer and fouling in submerged vacuum membrane distillation crystallization (VMDC) for inland brine water treatment. Journal of Membrane Science. 2016;520:679-92.

[188] Choi Y, Naidu G, Jeong S, Lee S, Vigneswaran S. Fractional-submerged membrane distillation crystallizer (F-SMDC) for treatment of high salinity solution. Desalination. 2018;440:59-67.

[189] Luo L, Zhao J, Chung T-S. Integration of membrane distillation (MD) and solid hollow fiber cooling crystallization (SHFCC) systems for simultaneous production of water and salt crystals. Journal of Membrane Science. 2018;564:905-15.

[190] Ghaffour N, Lattemann S, Missimer T, Ng KC, Sinha S, Amy G. Renewable energydriven innovative energy-efficient desalination technologies. Applied energy. 2014;136:115565.

[191] Thu K, Kim Y-D, Amy G, Chun WG, Ng KC. A hybrid multi-effect distillation and adsorption cycle. Applied Energy. 2013;104:810-21.

[192] Chakraborty A, Saha BB, Koyama S, Ng KC. Specific heat capacity of a single component adsorbent-adsorbate system. Applied Physics Letters. 2007;90:171902. 
[193] Thu K, Kim Y-D, Myat A, Chakraborty A, Ng KC. Performance investigation of advanced adsorption desalination cycle with condenser-evaporator heat recovery scheme. Desalination and Water Treatment. 2013;51:150-63.

[194] Kim Y-D, Thu K, Ng KC, Amy GL, Ghaffour N. A novel integrated thermal-/membranebased solar energy-driven hybrid desalination system: Concept description and simulation results. Water Research. 2016;100:7-19.

[195] Im S-J, Choi J, Jeong S, Jang A. New concept of pump-less forward osmosis (FO) and low-pressure membrane (LPM) process. Scientific Reports. 2017;7:14569.

[196] McGinnis RL, Elimelech M. Energy requirements of ammonia-carbon dioxide forward osmosis desalination. Desalination. 2007;207:370-82.

[197] Liu Q, Liu C, Zhao L, Ma W, Liu H, Ma J. Integrated forward osmosis-membrane distillation process for human urine treatment. Water Research. 2016;91:45-54.

[198] Phuntsho S, Kim JE, Hong S, Ghaffour N, Leiknes T, Choi JY, et al. A closed-loop forward osmosis-nanofiltration hybrid system: Understanding process implications through full-scale simulation. Desalination. 2017;421:169-78.

[199] Maltos RA, Regnery J, Almaraz N, Fox S, Schutter M, Cath TJ, et al. Produced water impact on membrane integrity during extended pilot testing of forward osmosis - reverse osmosis treatment. Desalination. 2018;440:99-110.

[200] Achilli A, Cath TY, Childress AE. Selection of inorganic-based draw solutions for forward osmosis applications. Journal of Membrane Science. 2010;364:233-41.

[201] Ge Q, Ling M, Chung T-S. Draw solutions for forward osmosis processes: Developments, challenges, and prospects for the future. Journal of Membrane Science. 2013;442:225-37.

[202] Luo H, Wang Q, Zhang TC, Tao T, Zhou A, Chen L, et al. A review on the recovery methods of draw solutes in forward osmosis. Journal of Water Process Engineering. 2014;4:212-23.

[203] Zhang S, Wang P, Fu X, Chung T-S. Sustainable water recovery from oily wastewater via forward osmosis-membrane distillation (FO-MD). Water Research. 2014;52:112-21.

[204] Lee S, Kim Y, Hong S. Treatment of industrial wastewater produced by desulfurization process in a coal-fired power plant via FO-MD hybrid process. Chemosphere. 2018;210:4451.

[205] Neff RA. Solvent extractor. 1960.

[206] Zhao D, Chen S, Wang P, Zhao Q, Lu X. A Dendrimer-Based Forward Osmosis Draw Solute for Seawater Desalination. Industrial \& Engineering Chemistry Research. 2014;53:16170-5.

[207] Ge Q, Lau CH, Liu M. A Novel Multi-Charged Draw Solute That Removes Organic Arsenicals from Water in a Hybrid Membrane Process. Environmental Science \& Technology. 2018;52:3812-9. 
[208] Wang P, Cui Y, Ge Q, Fern Tew T, Chung T-S. Evaluation of hydroacid complex in the forward osmosis-membrane distillation (FO-MD) system for desalination. Journal of Membrane Science. 2015;494:1-7.

[209] Kumar R, Al-Haddad S, Al-Rughaib M, Salman M. Evaluation of hydrolyzed poly(isobutylene-alt-maleic anhydride) as a polyelectrolyte draw solution for forward osmosis desalination. Desalination. 2016;394:148-54.

[210] Gwak G, Jung B, Han S, Hong S. Evaluation of poly (aspartic acid sodium salt) as a draw solute for forward osmosis. Water Research. 2015;80:294-305.

[211] Shim S-M, Lee S-J, Kim W-S. Experimental study on the performance evaluation of vacuum distillation process for NH4HCO3 removal. Journal of Mechanical Science and Technology. 2013;27:1171-8.

[212] Nguyen NC, Chen S-S, Jain S, Nguyen HT, Ray SS, Ngo HH, et al. Exploration of an innovative draw solution for a forward osmosis-membrane distillation desalination process. Environmental Science and Pollution Research. 2018;25:5203-11.

[213] Ray SS, Chen SS, Nguyen NC, Nguyen HT, Dan NP, Thanh BX, et al. Exploration of polyelectrolyte incorporated with Triton-X 114 surfactant based osmotic agent for forward osmosis desalination. Journal of Environmental Management. 2018;209:346-53.

[214] Nguyen NC, Nguyen HT, Ho S-T, Chen S-S, Ngo HH, Guo W, et al. Exploring high charge of phosphate as new draw solute in a forward osmosis-membrane distillation hybrid system for concentrating high-nutrient sludge. Science of The Total Environment. 2016;557558:44-50.

[215] Ray SS, Chen S-S, Nguyen NC, Nguyen HT, Li C-W, Wang J, et al. Forward osmosis desalination by utilizing chlorhexidine gluconate based mouthwash as a reusable draw solute. Chemical Engineering Journal. 2016;304:962-9.

[216] Ge Q, Amy GL, Chung T-S. Forward osmosis for oily wastewater reclamation: Multicharged oxalic acid complexes as draw solutes. Water Research. 2017;122:580-90.

[217] Nguyen NC, Chen S-S, Ho S-T, Nguyen HT, Ray SS, Nguyen NT, et al. Optimising the recovery of EDTA-2Na draw solution in forward osmosis through direct contact membrane distillation. Separation and Purification Technology. 2018;198:108-12.

[218] Ge Q, Wang P, Wan C, Chung T-S. Polyelectrolyte-Promoted Forward OsmosisMembrane Distillation (FO-MD) Hybrid Process for Dye Wastewater Treatment. Environmental Science \& Technology. 2012;46:6236-43.

[219] Zhao D, Wang P, Zhao Q, Chen N, Lu X. Thermoresponsive copolymer-based draw solution for seawater desalination in a combined process of forward osmosis and membrane distillation. Desalination. 2014;348:26-32.

[220] Hartanto Y, Zargar M, Wang H, Jin B, Dai S. Thermoresponsive Acidic Microgels as Functional Draw Agents for Forward Osmosis Desalination. Environmental Science \& Technology. 2016;50:4221-8. 
[221] Kim J-j, Chung J-S, Kang H, Yu YA, Choi WJ, Kim HJ, et al. Thermo-responsive copolymers with ionic group as novel draw solutes for forward osmosis processes. Macromolecular Research. 2014;22:963-70.

[222] Kwon Y-N, Kim M-J, Lee YT. Application of a FO/MD-combined system for the desalination of saline solution. Desalination and Water Treatment. 2016;57:14347-54.

[223] Husnain T, Liu Y, Riffat R, Mi B. Integration of forward osmosis and membrane distillation for sustainable wastewater reuse. Separation and Purification Technology. 2015;156:424-31.

[224] Husnain T, Mi B, Riffat R. Fouling and long-term durability of an integrated forward osmosis and membrane distillation system. Water Science and Technology. 2015;72:2000-5.

[225] Li J, Hou D, Li K, Zhang Y, Wang J, Zhang X. Domestic wastewater treatment by forward osmosis-membrane distillation (FO-MD) integrated system. Water Science and Technology. 2018;77:1514-23.

[226] Volpin F, Chekli L, Phuntsho S, Ghaffour N, Vrouwenvelder JS, Shon HK. Optimisation of a forward osmosis and membrane distillation hybrid system for the treatment of sourceseparated urine. Separation and Purification Technology. 2019;212:368-75.

[227] Xie M, Nghiem LD, Price WE, Elimelech M. A Forward Osmosis-Membrane Distillation Hybrid Process for Direct Sewer Mining: System Performance and Limitations. Environmental Science \& Technology. 2013;47:13486-93.

[228] Yu L, Han M, He F. A review of treating oily wastewater. Arabian Journal of Chemistry. 2017;10:S1913-S22.

[229] Yao M, Woo YC, Tijing LD, Choi J-S, Shon HK. Effects of volatile organic compounds on water recovery from produced water via vacuum membrane distillation. Desalination. 2018;440:146-55.

[230] Mohammadi T, Kazemimoghadam M, Saadabadi M. Modeling of membrane fouling and flux decline in reverse osmosis during separation of oil in water emulsions. Desalination. 2003;157:369-75.

[231] Tijing LD, Choi J-S, Lee S, Kim S-H, Shon HK. Recent progress of membrane distillation using electrospun nanofibrous membrane. Journal of Membrane Science. 2014;453:435-62.

[232] Kim Y, Elimelech M, Shon HK, Hong S. Combined organic and colloidal fouling in forward osmosis: Fouling reversibility and the role of applied pressure. Journal of Membrane Science. 2014;460:206-12.

[233] Li X-M, Zhao B, Wang Z, Xie M, Song J, Nghiem LD, et al. Water reclamation from shale gas drilling flow-back fluid using a novel forward osmosis-vacuum membrane distillation hybrid system. Water Science and Technology. 2014;69:1036-44.

[234] Kim GD, Toy L, Hendren Z, Choi YC, Lesemann M, Buisson H. Integrated Forward Osmosis/Membrane Distillation Process Technology for Industrial Water Treatment and Reuse. 2017:V001T03A2. 
[235] Lu D, Liu Q, Zhao Y, Liu H, Ma J. Treatment and energy utilization of oily water via integrated ultrafiltration-forward osmosis-membrane distillation (UF-FO-MD) system. Journal of Membrane Science. 2018;548:275-87.

[236] Song H, Xie F, Chen W, Liu J. FO/MD hybrid system for real dairy wastewater recycling. Environmental Technology. 2017:1-11.

[237] Zhou Y, Huang M, Deng Q, Cai T. Combination and performance of forward osmosis and membrane distillation (FO-MD) for treatment of high salinity landfill leachate. Desalination. 2017;420:99-105.

[238] Wang KY, Teoh MM, Nugroho A, Chung T-S. Integrated forward osmosis-membrane distillation (FO-MD) hybrid system for the concentration of protein solutions. Chemical Engineering Science. 2011;66:2421-30.

[239] An X, Hu Y, Wang N, Zhou Z, Liu Z. Continuous juice concentration by integrating forward osmosis with membrane distillation using potassium sorbate preservative as a draw solute. Journal of Membrane Science. 2019;573:192-9.

[240] Wu C-Y, Chen S-S, Zhang D-Z, Kobayashi J. Hg removal and the effects of coexisting metals in forward osmosis and membrane distillation. Water Science and Technology. 2017;75:2622-30.

[241] Kim Y, Woo YC, Phuntsho S, Nghiem LD, Shon HK, Hong S. Evaluation of fertilizerdrawn forward osmosis for coal seam gas reverse osmosis brine treatment and sustainable agricultural reuse. Journal of Membrane Science. 2017;537:22-31.

[242] Youssef PG, Al-Dadah RK, Mahmoud SM. Comparative Analysis of Desalination Technologies. Energy Procedia. 2014;61:2604-7.

[243] Moon AS, Lee M. Energy Consumption in Forward Osmosis Desalination Compared to other Desalination Techniques. International Journal of Chemical, Molecular, Nuclear, Materials and Metallurgical Engineering. 2012;6:420-3.

[244] Koo J-W, Han J-H, Yun T, Lee S, Choi J-S. Integration of forward osmosis with membrane distillation: effect of operating conditions. Desalination and Water Treatment. 2013;51:5355-61.

[245] Cath TY, Childress AE, Martinetti CR. Combined Membrane-Distillation-ForwardOsmosis Systems and Methods of Use. USA2011.

[246] Ghaffour N, Francis L, Li Z, Valladares R, Alsaadi AS, Abu-Ghdaib M, Ghdaib MA, et al. Osmotically and thermally isolated forward osmosis-membrane distillation (fo-md) integrated module for water treatment applications. In: World Intellectual Property O, editor.: King Abdullah University Of Science And Technology; 2016.

[247] Kim Y, Li S, Francis L, Li Z, Valladares R, Alsaadi AS, Son HS, Amy A, Ghaffour N. Osmotically and thermally isolated FO-MD integrated module. Environmental Science \& Technology. 2019;53:3488-3498.

[248] Pattle RE. Production of Electric Power by mixing Fresh and Salt Water in the Hydroelectric Pile. Nature. 1954;174:660. 
[249] Loeb S, Van Hessen F, Shahaf D. Production of energy from concentrated brines by pressure-retarded osmosis: II. Experimental results and projected energy costs. Journal of Membrane Science. 1976;1:249-69.

[250] Helfer F, Lemckert C, Anissimov YG. Osmotic power with Pressure Retarded Osmosis: Theory, performance and trends - A review. Journal of Membrane Science. 2014;453:337-58.

[251] Schaetzle O, Buisman CJN. Salinity Gradient Energy: Current State and New Trends. Engineering. 2015;1:164-6.

[252] Straub AP, Deshmukh A, Elimelech M. Pressure-retarded osmosis for power generation from salinity gradients: is it viable? Energy \& Environmental Science. 2016;9:31-48.

[253] Kezia K, Lee J, Weeks M, Kentish S. Direct contact membrane distillation for the concentration of saline dairy effluent. Water Research. 2015;81:167-77.

[254] Lee J-G, Kim Y-D, Shim S-M, Im B-G, Kim W-S. Numerical study of a hybrid multistage vacuum membrane distillation and pressure-retarded osmosis system. Desalination. 2015;363:82-91.

[255] Kim J, Park M, Shon HK, Kim JH. Performance analysis of reverse osmosis, membrane distillation, and pressure-retarded osmosis hybrid processes. Desalination. 2016;380:85-92.

[256] Chae SH, Seo J, Kim J, Kim YM, Kim JH. A simulation study with a new performance index for pressure-retarded osmosis processes hybridized with seawater reverse osmosis and membrane distillation. Desalination. 2018;444:118-28.

[257] Han G, Zuo J, Wan C, Chung T-S. Hybrid pressure retarded osmosis-membrane distillation (PRO-MD) process for osmotic power and clean water generation. Environmental Science: Water Research \& Technology. 2015;1:507-15.

[258] McGinnis RL, McCutcheon JR, Elimelech M. A novel ammonia-carbon dioxide osmotic heat engine for power generation. Journal of Membrane Science. 2007;305:13-9.

[259] Lin S, Yip NY, Cath TY, Osuji CO, Elimelech M. Hybrid Pressure Retarded OsmosisMembrane Distillation System for Power Generation from Low-Grade Heat: Thermodynamic Analysis and Energy Efficiency. Environmental Science \& Technology. 2014;48:5306-13.

[260] Shaulsky E, Boo C, Lin S, Elimelech M. Membrane-Based Osmotic Heat Engine with Organic Solvent for Enhanced Power Generation from Low-Grade Heat. Environmental Science \& Technology. 2015;49:5820-7.

[261] Hickenbottom KL, Vanneste J, Cath TY. Assessment of alternative draw solutions for optimized performance of a closed-loop osmotic heat engine. Journal of Membrane Science. 2016;504:162-75.

[262] Hickenbottom KL, Vanneste J, Miller-Robbie L, Deshmukh A, Elimelech M, Heeley $\mathrm{MB}$, et al. Techno-economic assessment of a closed-loop osmotic heat engine. Journal of Membrane Science. 2017;535:178-87.

[263] Hickenbottom KL, Miller-Robbie L, Vanneste J, Marr JM, Heeley MB, Cath TY. Comparative life-cycle assessment of a novel osmotic heat engine and an organic Rankine 
cycle for energy production from low-grade heat. Journal of Cleaner Production. 2018;191:490-501.

[264] Straub AP, Yip NY, Lin S, Lee J, Elimelech M. Harvesting low-grade heat energy using thermo-osmotic vapour transport through nanoporous membranes. Nature Energy. 2016;1:16090.

[265] Straub AP, Elimelech M. Energy Efficiency and Performance Limiting Effects in Thermo-Osmotic Energy Conversion from Low-Grade Heat. Environmental Science \& Technology. 2017;51:12925-37.

[266] Park K, Kim DY, Yang DR. Theoretical Analysis of Pressure Retarded Membrane Distillation (PRMD) Process for Simultaneous Production of Water and Electricity. Industrial \& Engineering Chemistry Research. 2017;56:14888-901.

[267] Ren M, Ning P, Xu J, Qu G, Xie R. Concentration and treatment of ceric ammonium nitrate wastewater by integrated electrodialysis-vacuum membrane distillation process. Chemical Engineering Journal. 2018;351:721-31.

[268] Sardari K, Fyfe P, Lincicome D, Ranil Wickramasinghe S. Combined electrocoagulation and membrane distillation for treating high salinity produced waters. Journal of Membrane Science. 2018;564:82-96.

[269] Tongwen X, Chuanhui H. Electrodialysis-based separation technologies: A critical review. AIChE Journal. 2008;54:3147-59.

[270] Eleiwi F, Ghaffour N, Alsaadi AS, Francis L, Laleg-Kirati TM. Dynamic modeling and experimental validation for direct contact membrane distillation (DCMD) process. Desalination. 2016;384:1-11.

[271] Lee JG, Lee EJ, Jeong S, Guo J, An AK, Guo H, Kim J, Leiknes T, Ghaffour N. Theoretical modeling and experimental validation of transport and separation properties of carbon nanotube electrospun membrane distillation. Journal of Membrane Science. 2017;526:395-408. 